UNIVERSIDADE DE SÃO PAULO

INSTITUTO DE GEOCIÊNCIAS

\title{
POLUIÇÃO DE AQUíFERO COSTEIRO DE AREMBEPE-BA POR ÁCIDO SULFÚRICO E COMPOSTOS INORGÂNICOS ORIUNDOS DA PRODUÇÃO DE DIÓXIDO DE TITÂNIO
}

Daniel Caminero Gomes

Orientador: Prof. Dr. Robert William Cleary

DISSERTAÇÃO DE MESTRADO

Programa de Pós-Graduação em Recursos Minerais e Hidrogeologia 
UNIVERSIDADE DE SÅO PAULO

INSTITUTO DE GEOCIENCIAS

\title{
POLUIÇÃO DE AQUÍFERO COSTEIRO DE AREMBEPE-BA POR ÁCIDO SULFÚRICO E COMPOSTOS INORGÂNICOS ORIUNDOS DA PRODUÇÃO DE DIÓXIDO DE TITÂNIO
}

\author{
Daniel Caminero Gomes
}

Orientador: Prof. Dr. Robert William Cleary

DISSERTAÇÃO DE MESTRADO

COMISSÃO JULGADORA

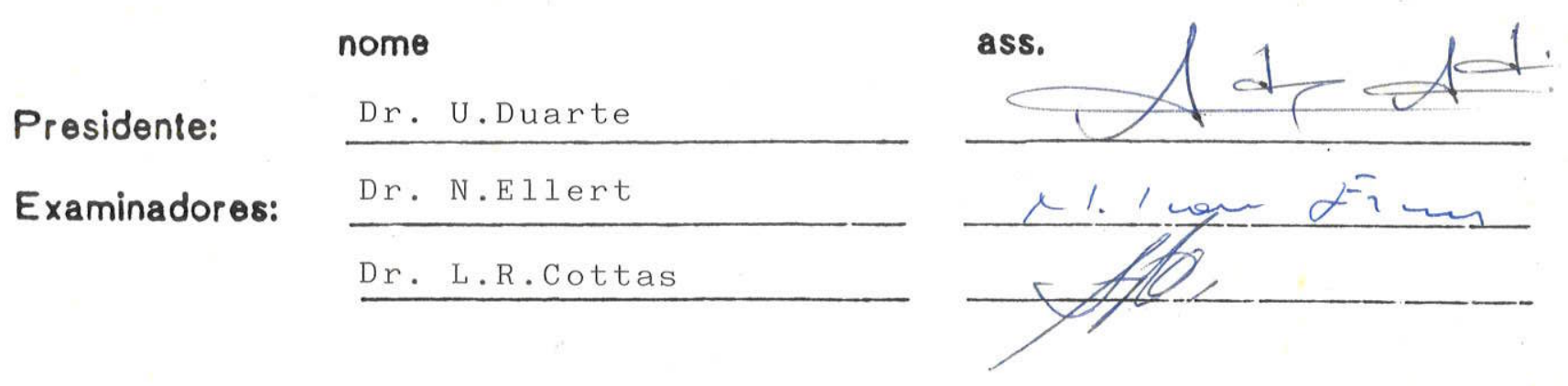


UNIVERSIDADE DE SÃO PAULO

INSTITUTO DE GEOCIENNCIAS

DEDALUS - Acervo - IGC

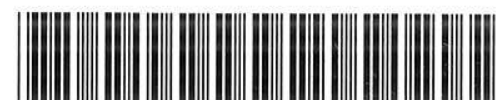

30900005025

\title{
POLUIÇÃO DE AQUÍFERO COSTEIRO DE AREMBEPE-BA POR ÁCIDO SULFÚRICO E COMPOSTOS INORGÂNICOS ORIUNDOS DA PRODUÇÃO DE DIÓXIDO DE TITÂNIO
}

\author{
Daniel Caminero Gomes
}

Orientador: Prof. Dr. Robert William Cleary

DISSERTAÇÃO DE MESTRADO

Programa de Pós-Graduação em Recursos Minerais e Hidrogeologia

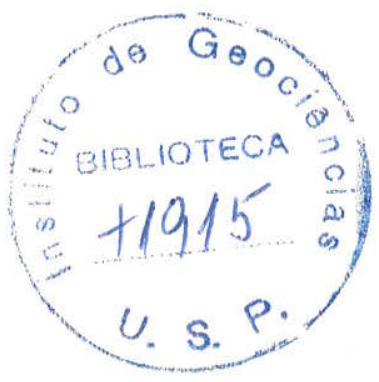

$$
\begin{gathered}
\text { SÃO PAULO } \\
1994
\end{gathered}
$$


A meus pais, Jorge e Roma e minha nova famslia, Pinky e Marisol, pelo amor e carinho. 


\section{Agradecimentos}

Trabalhos na área de proteção ambiental envolvem a participação de uma equipe multidisciplinar de colaboradores. o autor expressa um agradecimento a todos $e$, em especial:

A Diretoria da TIBRÁS - Titânio do Brasil S.A., em especial ao Dr. Manoel Geraldo de Andrade e Dr. Axel Westerhaus, que permitiram a publicação dos dados desta pesquisa, empenhando-se firmemente na recuperação ambiental das áreas degradadas.

A Diretoria da CSD-GEOKLOCK, nas pessoas do Dr. Ernesto N. Moeri e Carlos F. Egli, pelo apoio, interesse e revisóes técnicas.

Ao prof. Dr. Robert $W$. Cleary orientador deste trabalho, pelo incentivo e discussōes sobre metodologias de estudo.

Ao prof. Dr. José Milton B. Mendes, pelo apoio e comentários.

Aos funcionários da TIBRÁs Ariosvaldo Bezerra, Júlio Cézar P. Castro e Jurgen Fink, pelo apoio aos trabalhos de campo.

Aos Colegas e Amigos:

- Marcelo Alarsa, cujo apoio foi fundamental para a realização deste trabalho, principalmente nos trabalhos de campo;

- Maria Cristina salvador, pelas discussões sobre o comportamento hidroquímico dos poluentes;

- René Büchler, Lilian Poll e Marcia Weege, engenheiros responsáveis pelas obras de impermeabilização dos residuos, pelo auxilio na redação do capitulo correspondente;

- Michel Marrel, pelas discussōes quanto às técnicas e dimensionamento da remediação das águas subterrâneas;

- Marco A. Moura, pelas discussōes sobre taxas de lixiviação dos residuos;

- Claudia $S$. Dias, pelo alto nivel e incrivel rapidez nos trabalhos de digitação do texto; e

- Juscelino B. Mendonça e Dimas A. Fuentes, pela paciência e execução das ilustrações deste trabalho. 


\section{RESUMO}

o objetivo central deste trabalho é avaliar o impacto às águas subterrâneas devido à disposição não-controlada de residuos sólidos industriais em dunas recentes, assim como vazamentos de ácido sulfúrico acidentais ocorridos em indústria de Dióxido de Titânio, situada nas proximidades de Arembepe, municipio de Camaçari, BA. Adicionalmente, pretende descrever os processos envolvidos e as medidas de recuperação ambiental adotadas.

- local foi investigado através de trabalhos de geofisica (sondagens elétricas e caminhamento elétrico), seguidos de instalação de poços de monitoração e cinco campanhas de amostragem/análise química de águas, para compostos inorgânicos e parâmetros "in situ" ( $\mathrm{pH}$, temperatura, condutividade elétrica). Foram também realizados ensaios de bombeamento e permeabilidade para caracterizaçāo hidráulica do aquifero local.

Os resultados mostraram a presença de um aquifero principal pouco espesso formado por areias finas, cujas aguas subterrâneas movemse em dois sentidos principais: para o oceano (sudeste) e para o rio Capivara Grande, a noroeste. As velocidades de escoamento são relativamente altas, entre 60 e $690 \mathrm{~m} / \mathrm{ano}$.

A deposição dos residuos nas dunas causou um expressivo impacto na qualidade das águas subterrâneas, principalmente devido aos Ions sulfato, ferro solúvel e baixos valores de $p H$, migrando em direção ao rio Capivara Grande, principalmente. Os vazamentos e perdas de poluentes na área industrial contribuiram para a formação de uma extensa pluma de poluição em sentido ao oceano.

A acidificação do aquifero também levou à mobilização de ions que podem provocar efeitos tóxicos à flora local, como Aluminio e Manganês. 
A poluição atingiu alguns poços rasos, inutilizando-os. Além disso, algumas lagoas sofreram intenso processo de acidificação, prejudicando a vida aquática.

Para mitigar este impacto, foram implantadas as seguintes medidas de remediação: impermeabilização dos residuos com camadas de argila-bentonita compactadas, protegidas por solo argiloso não compactado e areias das dunas; implantação de poços de bombeamento das águas subterrâneas e bombeamento de uma lagoa inter-dunas. As águas bombeadas são enviadas a emissário submarino de $3 \mathrm{Km}$ de distância da costa. Além disso, foi iniciado um trabalho de plantio de espécies nativas.

o pouco tempo de operação do sistema, ainda parcial, impede uma avaliação detalhada quanto à recuperação da área, entretanto, já houve uma melhoria de qualidade das águas subterrâneas a noroeste da área, provavelmente devido à impermeabilização dos residuos. Por outro lado, foi constatado um aumento na poluição na área industrial, devido a novas perdas de ácido sulfúrico, as quais deveriam ser imediatamente reparadas. 


\section{ABSTRACT}

The main objective of this work is to evaluate the impact to groundwater quality due to the ancient, uncontrolled disposal of inorganic industrial solid wastes onto sand dunes, together with accidental sulfuric acid leakages, occurred at a ritanium Dioxide plant, located at Arembepe, Camaçari County, state of Bahia, Brazil .

The region is partially supplied with groundwater wells, some of them being damaged by the contamination. Besides, some lagoons were intensively acidifyed, with consequent damages to aquatic Iife.

The study area was investigated by means of geophysical surveys (resistivity, electric soundings and profiles), followed by monitoring wells installation and five water sampling/chemical analysis campaigns, for inorganic compounds. In addition, pumping and slug tests were performed, in order to characterize the local aquifer hydraulic parameters.

Results have shown a sandy aquifer of small thickness, which waters migrate in two directions: towards the ocean (southeast) and the Capivara Grande river (northwest), at relatively high seepage velocities: 60 to $690 \mathrm{~m} / \mathrm{yr}$.

The leaching of the solid wastes had provoked high concentrations of sulfate, iron and low $\mathrm{pH}$ values, mainly in direction towards the Capivara Grande river, whereas the industrial pollution plume migrates in direction towards the ocean.

The aquifer acidification has also solubilized some metals that are phyto-toxic, like aluminium and managenese for instance. 
The following remedial measures were taken:

- solid wastes containment, with mineralogical clay-bentonite covering layers, protected by clayey soil and dune sands;

- installation of pumping wells and pumping of a contaminated lagoon to a $3 \mathrm{Km}$ lenth-outfall into the ocean; and

- landscape recovery, using native species.

Due to the short time in operation, the remedial system cannot be evaluated in detail at the moment. However, some quality improvement was achieved at the northwest plume, probably due to the wastes covering system. On the other hand, the plume increased to southeast, due to recent $\mathrm{H}_{2} \mathrm{SO}_{4}$ leakages at the industrial area, which should be immediately repaired. 
ÍNDICE

AGRADECIMENTOS

Pag.

RESUMO

ABSTRACT

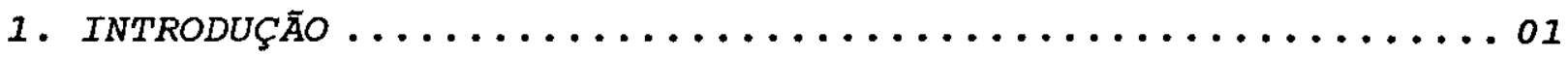

1.1. Descrição da Área de Estudo ................. 01

1.2. Considerações Gerais sobre o Dióxido de Titânio . . 03

1.3. Histórico do Processo Poluidor ............... 04

1.4. objetivos .......................... o7

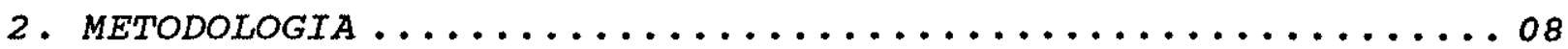

2.1. Pesquisa Bibliográfica sobre Casos similares ..... 08

2.2. Geofisica ......................... 13

2.2.1. Sondagens Elétricas Verticais .......... 13

2.2.2. Caminhamento Elétrico .............. 14

2.3. Implantação de Poços de Monitoração e

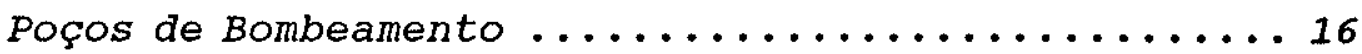

2.3.1. Poços de Monitoração ................ 16

2.3.2. Poços de Bombeamento e de Observação ...... 19

2.4. Ensaios Hidrogeológicos ................. 21

2.4.1. Medidas de nIvel d'Água e Ensaios de

Permeabilidade .................... 21

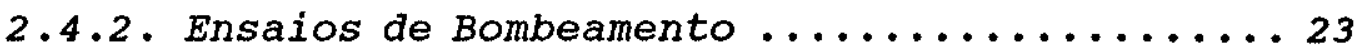

2.5. Amostragem e Análise Química de Águas ........... 24 
3. APRESENTAÇÃO E DISCUSSÃO DOS RESULTADOS $\ldots \ldots \ldots \ldots \ldots 26$

3.1. Hidrogeologia Regional ...................... 26

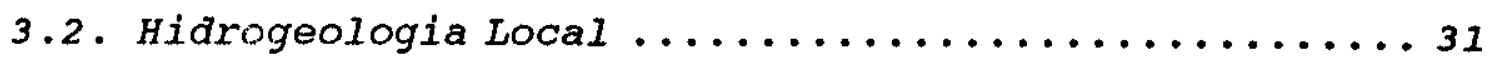

3.2.1. Aquiferos e niveis semi-confinantes ....... 31

3.2.2. Velocidade e sentido de fluxo ............. 35

3.2.3. Parâmetros hidrodinâmicos .............. 39

3.3. Geofisica .........................44

3.4. Impacto às Águas Subterrâneas .............48

3.4.1. Resultados Analiticos ...............48

3.4.2. Distribuição Espacial e Evolução Temporal dos Principais Parâmetros ............. 51

3.5. Balanço de Massa Preliminar ............... 87

4. MEDIDAS DE RECUPERAÇÃO AMBIENTAL $\ldots \ldots \ldots \ldots \ldots \ldots \ldots \ldots$

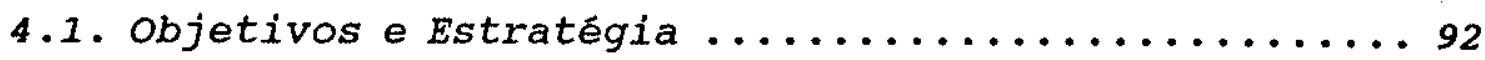

4.2. Eliminação de Fontes de contaminação ........... 95

4.2.1. Impermeabilização dos Residuos ......... 95

4.2.2. Eliminação de Fontes Industriais ......... 99

4.3. Recomposição da Paisagem ................... 99

4.4. Bombeamento e Destino Final das Águas Contaminadas 100

4.4.1. Bombeamento da Lagoa Inter-dunas ........ 100

4.4.2. Instalação de Poços de Bombeamento ........ 101

4.4.3. Destino Final das Águas Bombeadas ......... 105

4.5. Avaliação Preliminar das Medidas Adotadas ....... 106

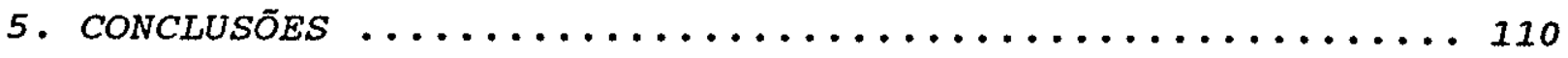

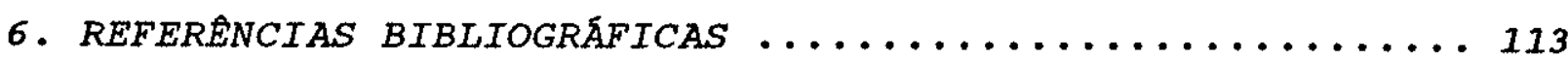




\section{LISTA DE FIGURAS}

Pág.

$1 \quad$ Localização da Área de Estudo ................. 02

2 Fontes Potenciais de Contaminação das Aguas e solos .. 06

3 Localização das Investigaçōes Geofísicas .......... 15

4 Perfil típico dos poços de Monitoração ............ 17

5 Localização dos Poços de Monitoração e Poços de

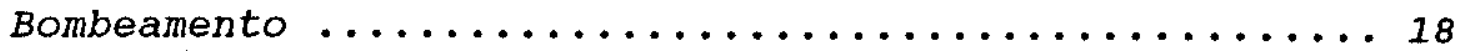

6 Perfil típico dos Poços de Bombeamento ........... 20

7 Localização da Bacía do Recôncavo ............... 28

8 Mapa Geológico Regional ................... 29

9 Dados Climatológicos - Região de Camaçari

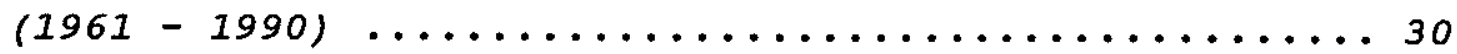

10 Localização das Seções Hidrogeológicas ... . . . . . . . 33

11 Seção Hidrogeológica $A-A^{\prime} \ldots \ldots \ldots \ldots \ldots \ldots \ldots \ldots$

12 Seção Hidrogeológica $B-B^{\prime} \ldots \ldots \ldots \ldots \ldots \ldots \ldots \ldots \ldots$

13 Seção Hidrogeológica $c-c^{\prime} \ldots \ldots \ldots \ldots \ldots \ldots \ldots \ldots \ldots$

14 Seção Hidrogeológica $D-D^{\prime} \ldots \ldots \ldots \ldots \ldots \ldots \ldots \ldots \ldots$

15 Seção Hidrogeológica $E-E^{\prime} \ldots \ldots \ldots \ldots \ldots \ldots \ldots \ldots \ldots$ 
16 Mapa Potenciométrico - Agosto/1992 ............. 36

17 Mapa Potenciométrico - Agosto/1993 ............. 37

18 Teste de Bombeamento - PBO1 ................ 42

19 Teste de Bombeamento - PO03 ................. 43

20 Isóbatas do Topo Rochoso Definidas pela Geofísica ... 46

21 Anomalias Geoelétricas Detectadas .............. 47

22 Isoconcentrações de Sulfato - Agosto/1992 ........ 56

23 Isoconcentraçōes de Sulfato - Janeiro/1993........ 57

24 Isoconcentrações de Sulfato - Maio/1993 .......... 58

25 Isoconcentrações de sulfato - Julho/1993 ......... 59

26 Isoconcentrações de Sulfato - Novembro/1993 .......6 60

27 Isovalores de $p H-$ Agosto/1992 ..............63

28 Isovalores de $p H-$ Janeiro/1993 ............. 64

29 Isovalores de $p H-$ Maio/1993 ...............65

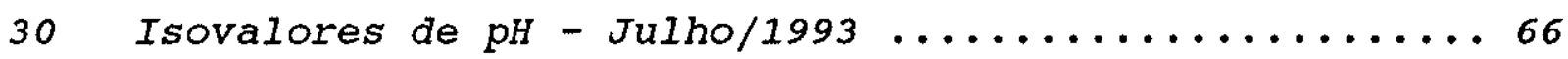

31 Isovalores de $p H-$ Novembro/1993 .............67

32 Isoconcentrações de Ferro Solúvel - Agosto/1992 .... 70

33 Isoconcentraçōes de Ferro Solúvel - Novembro/1993 ...71 
34 Isovalores de Condutividade Elétrica - Agosto/1992 . . 73

35 Isovalores de Condutividade Elétrica - Novembro/1993 • 74

36 Correlação entre sulfato e Condutividade Elétrica ... 75

37 Isoconcentraçōes de Titânio - Agosto/1992 ........78

38 Isoconcentraçōes de Aluminio - Agosto/1992 ....... 81

39 Medidas de Remediação : Estratégia de Ação ......... 94

40 Corte Esquemático dos Sistemas de Impermeabilização .. 98

41 Corte Esquemático do Poço - Dreno Horizontal ....... 102

42 Localização do Poço - Dreno Horizontal . . . . . . . . 103

43 Evolução Temporal : $P Z-25 \ldots \ldots \ldots \ldots \ldots \ldots$

44 Evolução Temporal : $P Z-24 \ldots \ldots \ldots \ldots \ldots$ 


\section{LISTA DE TABELAS}

Pag.

1 Quantificação dos Residuos Depositados nas Dunas .... 05

2 Valores de Condutividade Hidráulica obtidos $\ldots . \ldots . .38$

3 Parâmetros Hidrogeológicos obtidos nos Testes de Bombeamento .......................... 41

4 Resultados das Sondagens Elétricas $\ldots \ldots \ldots \ldots \ldots \ldots$

5 Resultados da Primeira Campanha de Análises Quimicas ............................ 49

6 Variação de $\mathrm{pH}$, Condutividade Elétrica e Sulfato nas Amostras de Água ..................... 50

7 Composição Química dos Residuos Dispostos nas Dunas .......................... 87

8 Total de Sulfato Contido as Águas Subterrâneas ..... 88

9 Resumo das Características Produtivas dos Poços

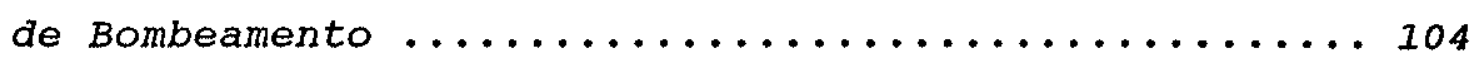




\section{INTRODUÇÃO}

\subsection{DESCRIÇÃO DA ÁREA DE ESTUDO}

A área de estudo escolhida situa-se em Arembepe, municipio de Camaçari, BA. O acesso é feito através de rodovia BA-099, a $23 \mathrm{Km}$ ao Norte de Salvador.

Neste local, situa-se a fábrica da TIBRÁS - TITÂNIO DO BRASIL $S . A .$, a aproximadamente $600 \mathrm{~m}$ do mar, junto a uma área de dunas semi-móveis, áreas alagadiças e várias lagoas (Figura 1). os principais produtos fabricados são o Dióxido de Titânio (pigmento branco) e o sulfato Ferroso (floculante). Este ultimo antigamente um residuo sólido descartado. Além destes produtos, a fábrica produz ácido sulfúrico para consumo interno.

Entre a fábrica e o mar, situa-se um condominio de alto padrão (Condominio Parque Interlagos), caracterizado por um sistema de canais artificiais interligados a uma lagoa. A oeste do terreno industrial, encontra-se o Bairro Areias, habitado por uma população de baixa renda. Ambos são abastecidos integralmente por águas subterrâneas. 


\section{Figura 1 - LOCALIZAÇĀO DA ÁREA DE ESTUdO}
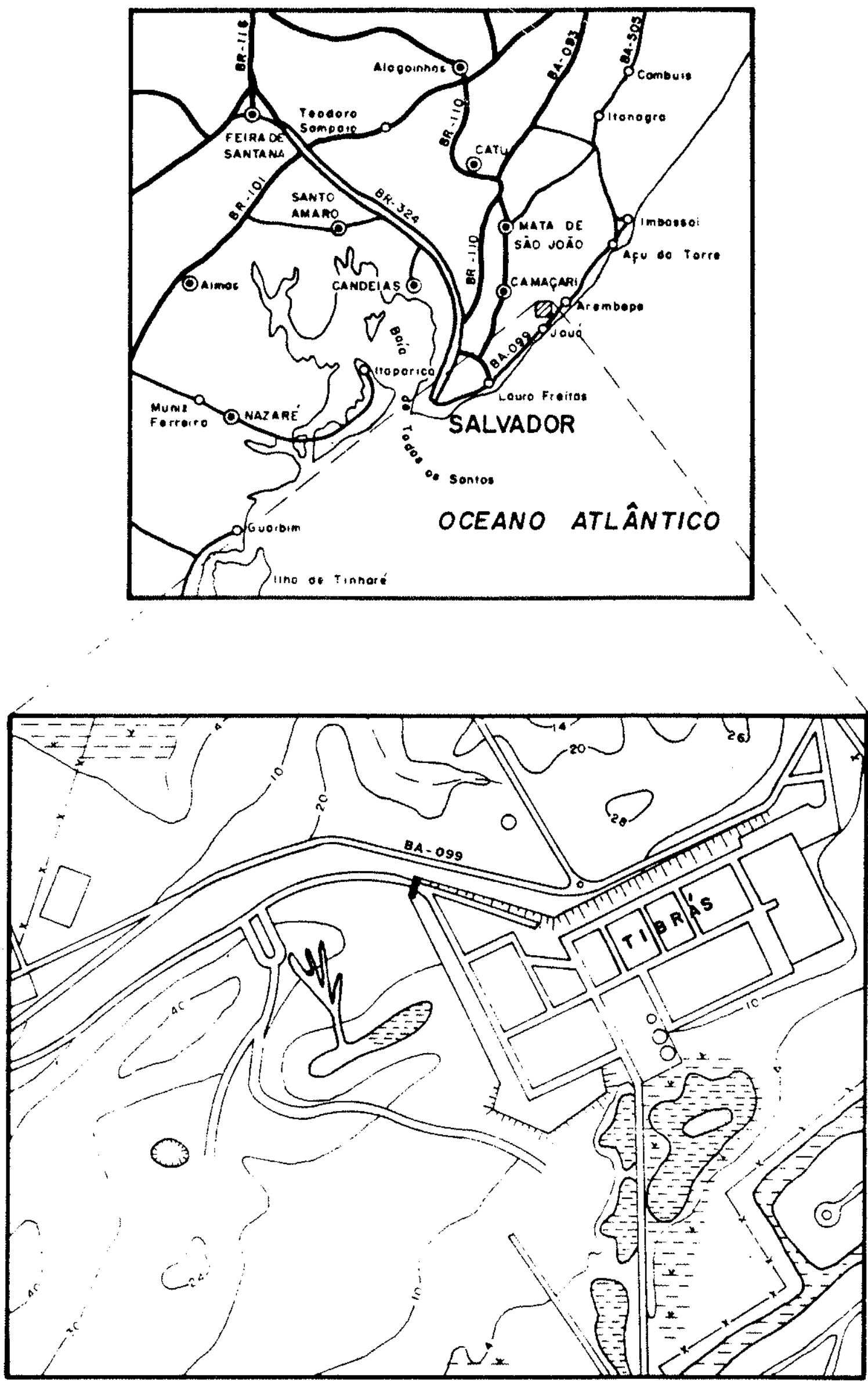

Pag. 02 


\subsection{CONSIDERAÇÕES GERATS SOBRE O DIÓXIDO DE TITANIO}

o dióxido de titânio ( $\left(\mathrm{TiO}_{2}\right)$ é o composto mais usado no mundo como pigmento branco para tintas de recobrimento de superficie (SHREVE e BRINK Jr, 1977). Isto se deve principalmente ao baixo custo por unidade de cobertura e excelente poder de cobertura.

- $\mathrm{TiO}_{2}$ é fabricado a partir do método de lixiviação a ácido sulfúrico quente ("sulfatização"), onde o mineral de ilmenita moldo é misturado com $\mathrm{H}_{2} \mathrm{SO}$, quente e a mistura agitada a vapor. Da solução resultante de sulfatos de titanio, sulfato ferroso e férrico (posteriormente reduzido a sulfato ferroso, por limalha ou sucata de $\mathrm{Fe}$ ), o $\mathrm{Fe}$ é removido como sulfato ferroso cristalizado por resfriamento, cristalização e centrifugação.

A solução ácida de sulfato de titanila (Tioso, é então concentrada e hidrolisada com soda caústica, sendo o precipitado filtrado a vácuo ( $\mathrm{TiO}_{2}$ insolúvel), novamente suspenso em água e refiltrado, para remoçāo do restante do sulfato ferroso, o qual é atualmente vendido como floculante para tratamento de água (após secagem ou não).

A torta de filtração é então re-suspensa e calcinada a $\mathrm{Ti}_{2}$ em fornos rotativos. Dependendo do produto a ser obtido, após a hidrólise, pode-se adicionar sementes (pequena quantidade) de rutilo ou anatásio, além de outros reagentes especificos (ácido fosfórico, $\mathrm{ZnO}, \mathrm{KCl}$, etc). Os efluentes, ricos em $\mathrm{Fe}^{2+}$ e $\mathrm{H}_{2} \mathrm{SO}_{4}$ são enviados ao emissário submarino, com $6 \mathrm{~km}$ de distância da costa, assim como os residuos pastosos provenientes das etapas de filtração com filtros-prensa (lama industrial).

Além deste processo, na planta da TIBRÁs é produzido o ácido sulfúrico usado no processo, a partir de enxofre, cal hidratada e diatomita, restando após filtração uma lama rica em enxofre (borra de enxofre), atualmente enviada ao emissário submarino. 


\subsection{HISTERICO DO PROCESSO POLUIDOR}

A fábrica da TIBRÁs foi instalada em 1971, tendo depositado seus resíduos industriais nas dunas semi-móveis próximas até 1982 (11 anos). Da mesma forma, residuos domésticos foram co-dispostos nas dunas, em pequenas células até 1990.

Estes residuos, com a infiltração das águas das chuvas, e lixiviação de compostos químicos, provocaram a contaminação de lagoas próximas, principalmente reduzindo $\mathrm{o} \mathrm{pH}$ e produzindo altas concentraçōes de $\mathrm{Fe}^{2+}$ e sulfatos, com consequente deteorização da paisagem. Além disso, processos erosivos causaram aparecimento de uma voçoroca de $17.300 \mathrm{~m}^{3}$, com transporte de residuos diretamente para uma lagoa entre as dunas.

Além disso, alguns poços rasos tipo cacimba no Bairro Areias foram contaminados, obrigando a indústria a fornecer água tratada, através de uma adutora a partir de sua Estação de Tratamento de Águas (ETA), situada junto ao rio Capivara Grande.

o mapeamento feito com sondagens a trado mostrou que os principais tipos de residuos dispostos, cuja localização encontra-se na Figura 2, são:

- borra de enxofre: proveniente da unidade de fabricação de $\mathrm{H}_{2} \mathrm{SO}_{4}$, possui coloração cinza-esverdeada e forma nódulos centimétricos. E composta por $60 \%$ de enxofre e $40 \%$ de água e silica.

- lama industrial: forma nódulos centimétricos de coloração cinza escura a preta, possuindo granulação argilosa e composição aproximada de $20 \%$ de $\mathrm{H}_{2} \mathrm{SO}_{4}, 7 \%$ de FeSO, 6 \% de Tioso, (sulfato de Titanila), $30 \%$ de ilmenita, $4 \%$ de silitica e $33 \%$ de água. Contém camadas centimétricas esparsas de enxofre nativo, com coloração típica amarela. 
- limalha de ferro: possui coloração típica marromavermelhada, sendo composta por óxidos hidratados de Fe.

- residuos domésticos: lixo doméstico resultante das atividades cotidiana da fábrica. Contém restos de madeira, residuos de restaurante, papéis, plásticos, etc.

A Tabela 1 mostra as áreas, volumes e massas de residuos dispostos no local.

\begin{tabular}{|c|c|c|c|}
\hline \multicolumn{4}{|c|}{$\begin{array}{l}\text { TABELA } 1 \text { - QUAMTIFICAÇAO DOS RES IDUOS DEPOSITADOS MAS DUMAS } \\
\text { (PER } 1000: 1971 \text { a 1982) }\end{array}$} \\
\hline RESIDUD & $\begin{array}{l}\text { AREA } \\
\left(\mathrm{m}^{2}\right)\end{array}$ & $\begin{array}{l}\text { VOLUME } \\
\left(m^{3}\right)\end{array}$ & $\begin{array}{l}\text { MASSA } \\
(t)\end{array}$ \\
\hline Domést ico & 34.500 & 64.700 & 97.050 \\
\hline $\begin{array}{l}\text { Industriat } \\
\text { (Borra de enxofre e Lama) }\end{array}$ & 52.700 & 39.500 & 63.000 \\
\hline Limalha de $\mathrm{Fe}$ & 7.800 & 3.120 & 18.700 \\
\hline Total & 95.000 & 107.320 & 178.750 \\
\hline
\end{tabular}

Modificado de GEOKLOCK (1990)

Além dos residuos sólidos, a própria fábrica apresenta várias fontes potenciais de contaminação das águas subterrâneas, mostradas na Figura 2, das quais destacam-se antigas perdas nos tanques e tubulaçōes de ácido sulfúrico concentrado (número 1, na Figura 2) e pátio de enxofre (ne 4), usado temporariamente como depósito de borras de enxofre, além de pequenos locais de antiga estocagem de residuos industriais ( $\mathrm{n}^{5} 5 \mathrm{e} 6$ ).

Acidentes no emissário submarino também representaram perdas para o subsolo, no passado. 


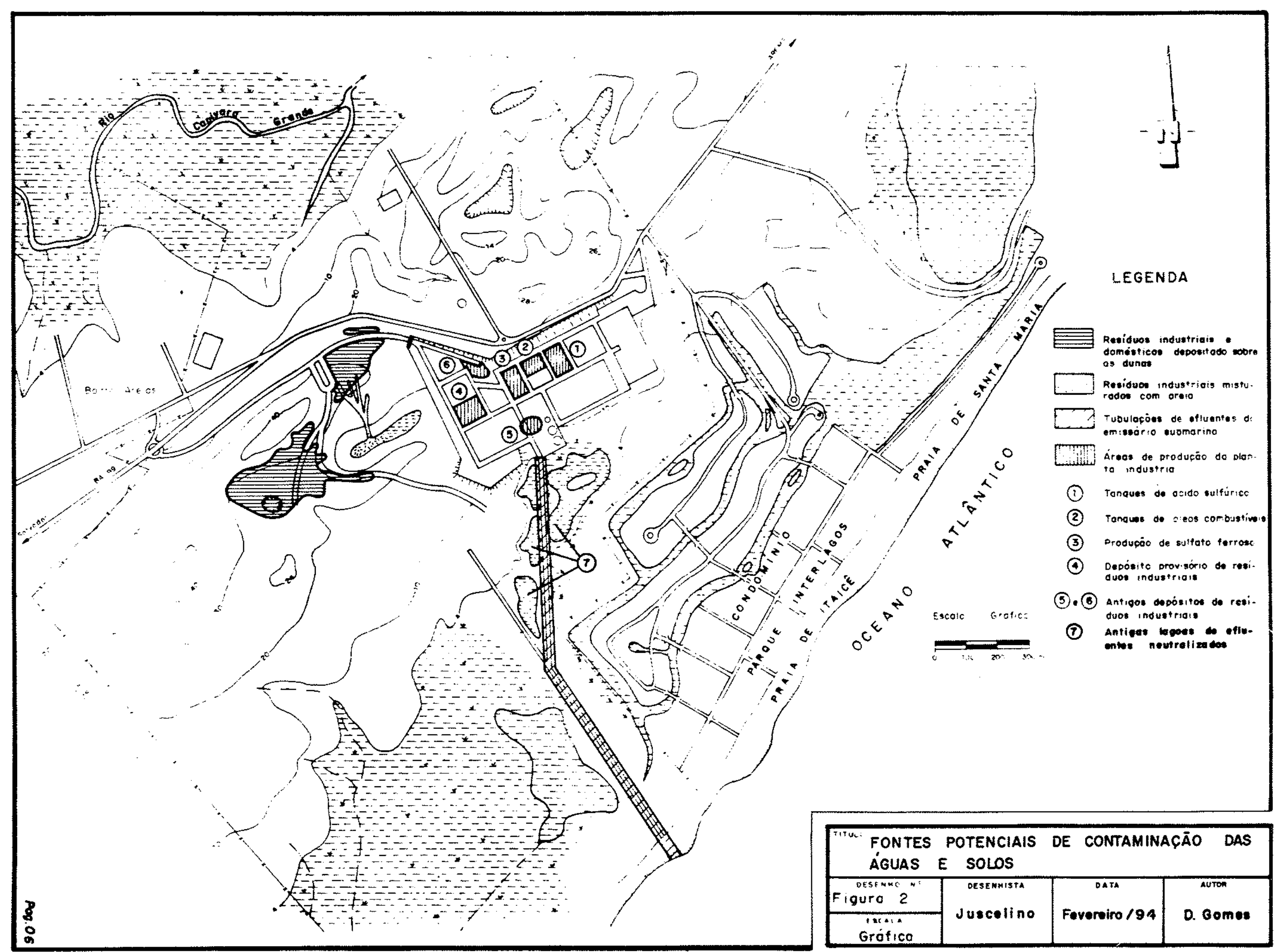




\subsection{OBJETIVOS}

os principais objetivos desta dissertação são:

- avaliar o impacto ambiental causado às águas subterrâneas locais pela disposição inadequada dos residuos inorgânicos no solo e demais fontes de contaminação de origem industrial;

- elaborar um modelo hidrogeológico conceitual da área;

- identificar os principais processos hidroquimicos envolvidos no transporte dos poluentes nas águas subterrâneas;

- implementar medidas concretas de remediação, para a recuperação ambiental do local. 


\section{METODOLOGIA}

\subsection{PESQUISA BIBLIOGRÁFICA SOBRE CASOS SIMILARES}

A disposicão inadequada de residuos ácidos ricos em sulfatos e ferro está geralmente ligada a drenagens ácidas e rejeitos de mineração há pelo menos desde o final da década de 60. Em 1969 EMRICH \& MERRITT (in TODD \& MCNULTY, 1976) encontraram concentraçōes elevadas de ferro e sulfato e baixo $p H$ nas águas subterrâneas provocadas pela oxidação e lixiviação de rejeitos de carvão, na região dos Apalaches, nos E.U.A.

A presença de outros metais pesados, incluindo zinco, chumbo e cádmio em altas concentraçōes, também foi relacionada à lixiviação de antigos bota-foras de residuos de mineração (MINK et.al., 1972, in TODD \& MCNULTY, 1976).

- processo de oxidação de sulfetos devido à ação de microorganismos, com consequente diminuição de pH e lixiviação de metais pesados para águas subterrâneas percolando rejeitos de mineração, foi descrito por GALBRAITH (1972, in TODD \& MCNULTY, 1976).

o delineamento preliminar de plumas de contaminação por drenagens ácidas de minas nas águas subterrâneas através de métodos geofisicos (eletrorressistividade) foi obtido com sucesso por MERKD em 1972 (in TODD \& MCNULTY, 1976). 
Mais recentemente, HELz et. al. (1987) citam que a oxidação da pirita é a principal causa da acidez. Sob condiçōes ácidas, destacam a importancia da bactéria Thiobacillus ferrooxidans como catalisador na oxidação do $\mathrm{Fe}^{2+}$ para $\mathrm{Fe}^{3+}$, etapa básica na oxidação da pirita dos depósitos de rejeitos de carvão. Os mesmos autores detectaram a precipitação de melanterita (FeSO, $7 \mathrm{H}_{2} \mathrm{O}$ - sulfato ferrosol e oxi-hidróxidos de $\mathrm{Fe}^{3+}$ em colunas de solos submetidas a efluentes com concentraçōes $0,2 \mathrm{M}$ de $\mathrm{SO}_{4}^{2-}, 0,1 \mathrm{M}$ Fe total e $\mathrm{pH}<2$. A mobilização de $\mathrm{Al}^{2+}$, Be e Cu também foi detectada, sendo os seguintes fatores admitidos como retardadores da oxidação da Pirita: diminuição da temperatura, diminuição da pressão parcial de oxigênio e adição de calcário.

DAVIS \& RUNNELLS (1987) relataram que o manejo inadequado de rejeitos de minerações e usinas de moagem de urânio também podem provocar lixiviados ácidos ricos em SO, $\mathrm{Al}, \mathrm{Ca}, \mathrm{Cl}, \mathrm{Fe}, \mathrm{Mn}$ e $\mathrm{Zn}$. Em ensaios de coluna, observaram que mesmo em solos com teores expressivos de calcita, o pH da solução percolante, apesar de um efeito-tampão inicial, continua baixo a longo prazo, devido ao recobrimento da calcita (cimentação) por precipitados amorfos de hidróxidos de $\mathrm{Fe}^{3+}$, sendo o ânion $\mathrm{SO}_{4}^{-2}$ considerado o melhor indicador do front de poluição. A precipitação destes hidróxidos é tida como um fator de atenuação da contaminação, uma vez que outros metais pesados são adsorvidos nos mesmos. o Ion sulfato pode sair da solução percolante como um precipitado do tipo AlOHSO, porém com pequeno efeito sobre a concentração total, mostrando poucos efeitos de retardamento, enquanto o Fe mostrou um retardamento significativo controlado pelas condiçōes de $\mathrm{pH}-$ Eh. 
HERLIHY, A.T. et. al. (1988) indicaram que drenagens ácidas de minas, ricas em $\mathrm{Fe}, \mathrm{SO}_{4}$ e baixo $\mathrm{pH}$, ao atingirem sedimentos de fundo do Lago Virginia (EUA), sofrem redução pela atividade microbiológica, formando sulfetos voláteis ácidos, enxofre elementar $\left(S^{\circ}\right)$ e pirita, sendo os dois primeiros os principais produtos a curto prazo (48 hs).

Conclusões semelhantes foram obtidas em 15 lagos em áreas de mineração de carvão nos EUA (WICKS et. al., 1991), onde foram encontrados sulfetos de $\mathrm{Fe}\left(\mathrm{FeS}_{2}\right)$ e $\mathrm{S}^{\circ}$, sendo a redução do enxofre limitada pela quantidade de matéria orgânica. Também o Fe e Mn presentes em áreas precipitam como óxidos nas zonas oxidantes, assim como compostos de enxofre (TARUTIS Jr. et. al., 1992) permanecem reduzidos nas zonas redutoras com tendência à formação de sulfetos metálicos. Neste estudo, houve pouca redução de sulfatos por ação de bactérias, provavelmente devido à pequena quantidade de matéria orgânica passivel de decomposição. Os autores concluem que as zonas pantanosas são eficientes na remoção de $\mathrm{Fe}$ e $\mathrm{Mn}$, devido à precipitação em forma de óxido/hidróxido.

Aproveitando este conceito, NORTON (1993) identifica as áreas pantanosas artificialmente construidas como um meio eficiente e barato de tratamento dos efluentes de drenagens ácidas de minas, mostrando que seu uso é cada vez mais popular nos EUA e apresenta tendências de crescimento na Europa. Segundo este autor, o principal efeito de oxidação de pirita se deve ao fato do enxofre produzir 3 vezes o seu peso em ácido sulfúrico. Os mecanismos purificadores das áreas pantanosas apontados são: oxidação e precipitação de óxidos de Fe, Mn e outros metais (zona oxidante), redução de sulfatos a sulfetos nos sedimentos de fundo (catalisados por bactérias) e consumo pelas plantas. 
Aplicaçōes de calcário, impermeabilização dos residuos e bombeamento/tratamento das águas subterrâneas também foram sugeridos (TODD \& MCNULTY, 1976).

Outra importante fonte de acidificação de solos e aquiferos se deve às deposiçōes ácidas controladas pela chuva/ventos. Esta fonte difere dos depósitos de residuos ácidos a céu aberto, no sentido de que a fonte, neste caso é difusa, atingindo grandes áreas, com sua sedimentação produzindo o acumulo de sulfatos e Ions $\mathrm{H}^{+}$, não ocorrendo a oxidação de sulfetos nos solos. Esta fonte é importante na área estudada, uma vez que a fábrica emite

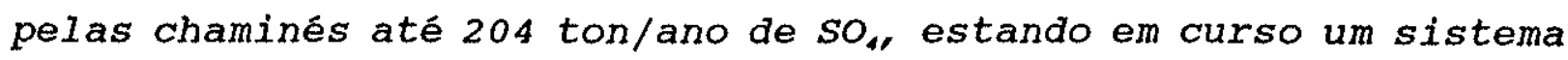
de oxidação úmida dos efluentes gasosos, que irá reduzir as emissōes em até 85 \% (FINK, 1993).

As deposições ácidas são particularmente importantes em áreas industriais, especialmente na Escandinávia e outros paises europeus, Canadá e os E.U.A. (JACKS, 1986). O mesmo autor aponta a capacidade - tampão dos solos como uma barreira temporária importante na proteção das águas subterrâneas, uma vez que os Ions $H^{+}$da água são trocados por lons $\mathrm{Ca}^{++}$e outros metais trocáveis do solo, tornando-o ácido, porém neutralizando as soluções percolantes. Entretanto, quando os solos já são naturalmente ácidos, como é típico em zonas úmidas devido à ação da vegetação que remove cátions trocáveis (nutrientes), este mecanismo purificador desaparece e todo efluente com eletrólitos solúveis provocará soluções percolantes ácidas.

Os Ions sulfato são considerados os responsáveis primários pela acidificação de ecossistemas aquáticos, podendo os nitratos também contribuirem significativamente (ENVIRONMENT CANADÁ, 1986). Os principais impactos apontados são o declínio de florestas, mortandade de peixes, acidificação de águas subterrâneas a longo prazo e problemas respiratórios em crianças. 
O aumento da mobilidade de $\mathrm{Al}, \mathrm{Cd}$ e $\mathrm{Zn}$ de solos, com consequente lixiviação e poluição de cursos d'água, também foi relacionado à redução de pH devido à deposição ácida, assim como outros metais pesados como $\mathrm{Hg}$ e $\mathrm{Pb}$ (KONSTEN et. al., 1993), dependendo da região industrial. Estes autores consideram a acidificação dos solos uma verdadeira bomba-relógio, devido ao efeito-tampão do solo, citando que os impactos devido a acidificação dos solos tornou-se evidente há cerca de 10 - 20 anos, enquanto que as deposições ácidas ocorrem na Europa há pelo menos 200 anos.

Alguns métodos para minimização dos impactos têm sido propostos, tais como controle artificial de $\mathrm{pH}$ (aplicação de $\mathrm{CaCO}_{3}$, principalmente) dos solos ácidos, de rios e lagos. Por exemplo, estudo feito na suécia mostrou resultados promissores, com elevação de alcalinidade das águas de um aquifero freático arenoso delgado ( 3 - $4 \mathrm{~m}$ de espessura), utilizando doses de 5 a 10 toneladas de $\mathrm{CaCO}_{3} /$ ha (JACKS \& NOORSTRÖM, 1986). Os mesmos autores recomendam o uso desta técnica em áreas de situação hidrogeológica simples (lençol freático aflorante, zona saturada pouco espessa, alta permeabilidade, etc).

Finalmente, a infiltração de efluentes liquidos da indústria alcooleira (vinhaça), em áreas de sacrificio (lagoas de infiltração), também produz efeitos de acidificação nas águas subterrâneas, com consequente aumento de metais, como ferro, aluminio, manganês e magnésio, solubilizados pela redução de $\mathrm{pH}$ e trocas iônicas ocorridas na zona não-saturada (HASSUDA, 1989). 


\subsection{GEOFISICA}

Para localizar a nivel preliminar, alterações químicas nas águas subterrâneas, devido à fontes de poluição, foi realizado um levantamento geofisico, usando-se o método da eletrorresistividade, com arranjos de eletrodos do tipo SCHLUMBERGER. A geofisica serviu também para uma primeira identificação da geometria do aquifero. Esta etapa inicial foi fundamental na locação dos poços de monitoração.

\subsubsection{Sondagens Elétricas Verticais}

Foram executadas 14 sondagens elétricas verticais (SEV), onde os eletrodos de corrente $(A-B)$ são simétrica e gradativamente distanciados a partir de um ponto central, sendo as leituras de resistividade aparente feitas em profundidades, que aumentam na medida em que se distanciam os eletrodos $A-B$. O objetivo principal foi o de avaliar as principais camadas geoelétricas, correlacionando-as à geologia local.

Foram feitas leituras até a profundidades de aproximadamente $24 \mathrm{~m}$. Os dados foram interpretados através de ábacos de ressistividade aparente e programa de computador SONDEL (CSD-Colombi Smutz Dorthe - Suiça). 


\subsubsection{Caminhamento Elétrico}

objetivando detectar anomalias relacionadas às plumas de poluição nas aguas subterrâneas, uma vez que as águas ricas em ions apresentam baixas ressistividades, foi realizada uma campanha de caminhamento elétrico de 16 quilômetros, com leituras de resistividade aparente a cada $40-60 \mathrm{~m}$.

Neste caso, os eletrodos são mantidos em posiçōes fixas entre si (mesma distância), investigando-se uma mesma profundidade, aproximadamente. Neste caso adotam-se a profundidade média de $15 \mathrm{~m}$.

A Figura 3 mostra a localização das sondagens elétricas e linhas de caminhamento elétrico. 


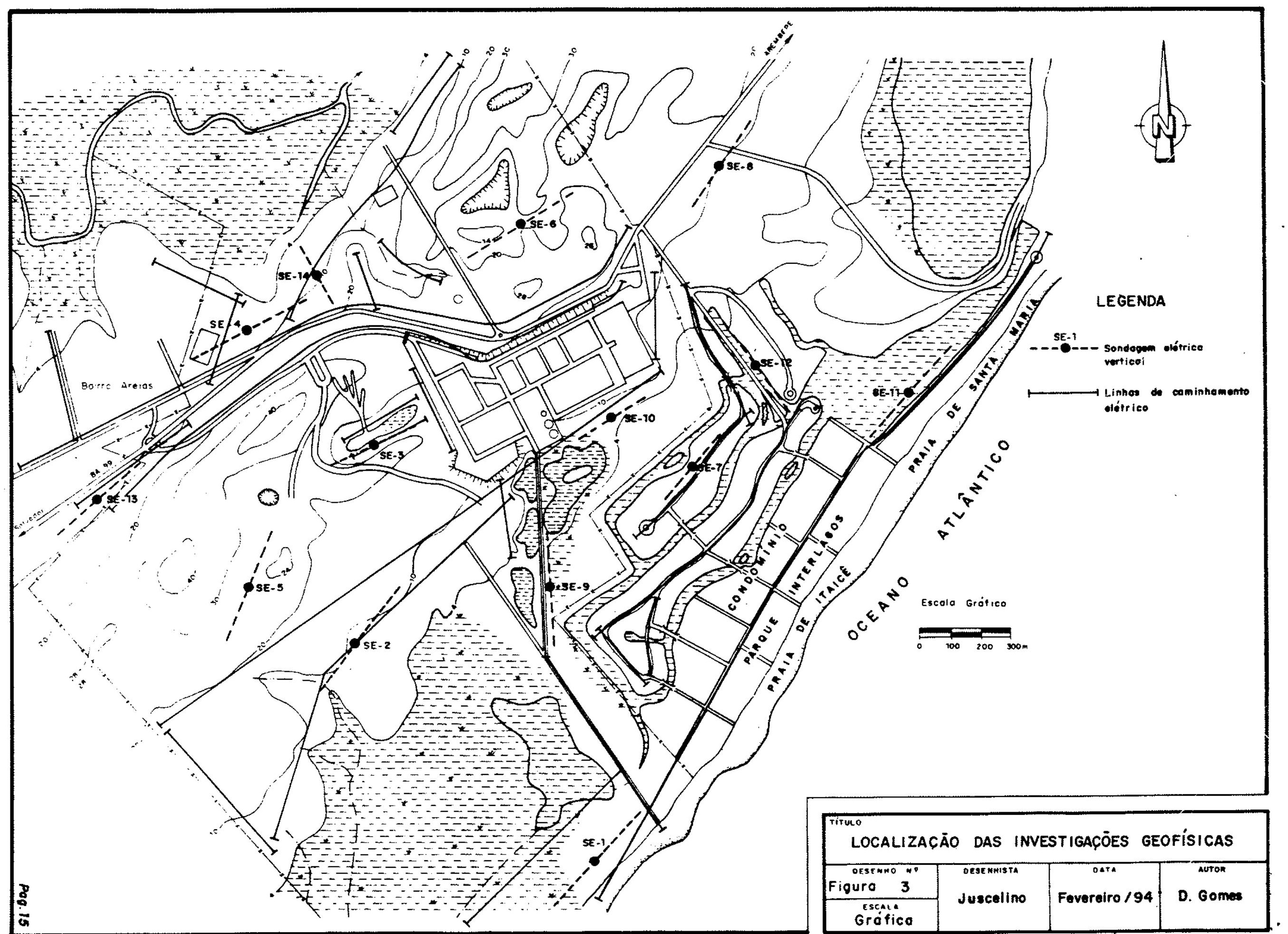


2.3. IMPLANTAÇÃO DE POÇOS DE MONITORAÇÃo E POÇOS DE BOMBEAMENTO 2.3.1. Poços de Monitoração

Foram instalados 37 poços de monitoração em duas fases distintas (julho/92 e julho/93), além de 2 poços antigos já existentes (SP04 e SP06), remanescentes de uma rede instalada em agosto de 1991, infelizmente desativada.

o perfil típico destes poços encontra-se na Figura 4 e suas localizações na Figura 5.

Basicamente são confeccionados em tubos de PVC rígido (JS Classe 15) de $60 \mathrm{~mm}$ de diâmetro interno, com filtros ranhurados de $1,5 \mathrm{~m}$, envoltos em manta de poliester não tecido (com condutividade hidráulica de $\left.10^{-1} \mathrm{~cm} / \mathrm{s}\right)$, para evitar a entrada de finos facilitando a amostragem futura. Este procedimento foi necessário, devido ao caráter não-consolidado dos sedimentos locais e granulometria fina.

As sondagens foram feitas no sistema percussivo em $100-150 \mathrm{~mm}$ de diâmetro. Não foram usadas lamas de perfuração, para evitar a adsorção de metais e outros cátions (FOSTER \& GOMES, 1989). Para evitar o desmoronamento da perfuração, foi usado revestimento temporário.

o espaço anelar entre a sondagem e o tubo de PVC foi preenchido com areia grossa quartzosa $(2-3 \mathrm{~mm})$ quando possivel, e bentonita (pó), visando selar o intervalo de amostragem e evitar a entrada d'água da superficie. Na parte superior dos piezômetros foi construida uma lage de concreto para proteção sanitária e confeccionada uma tampa lacrada em aço-carbono, pintada com tinta epóxi para evitar a corrosão atmosférica.

Os piezômetros foram desenvolvidos com amostradores tipo caçamba (agitação/remoção), até a remoção dos finos presentes. 
Figura 4 - PERFIL TíPICO DOS POÇOS DE
MONITORAGĀO

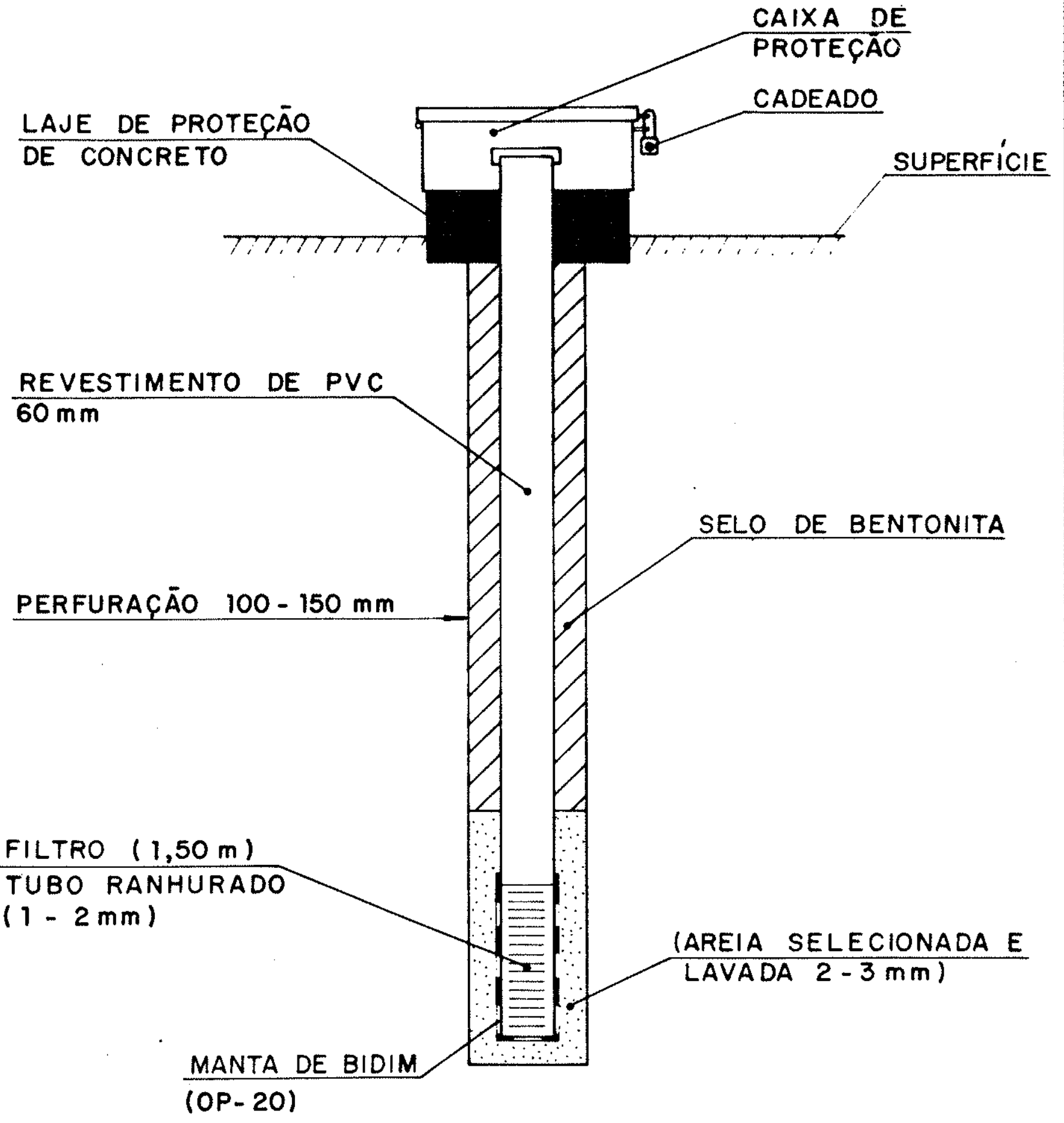




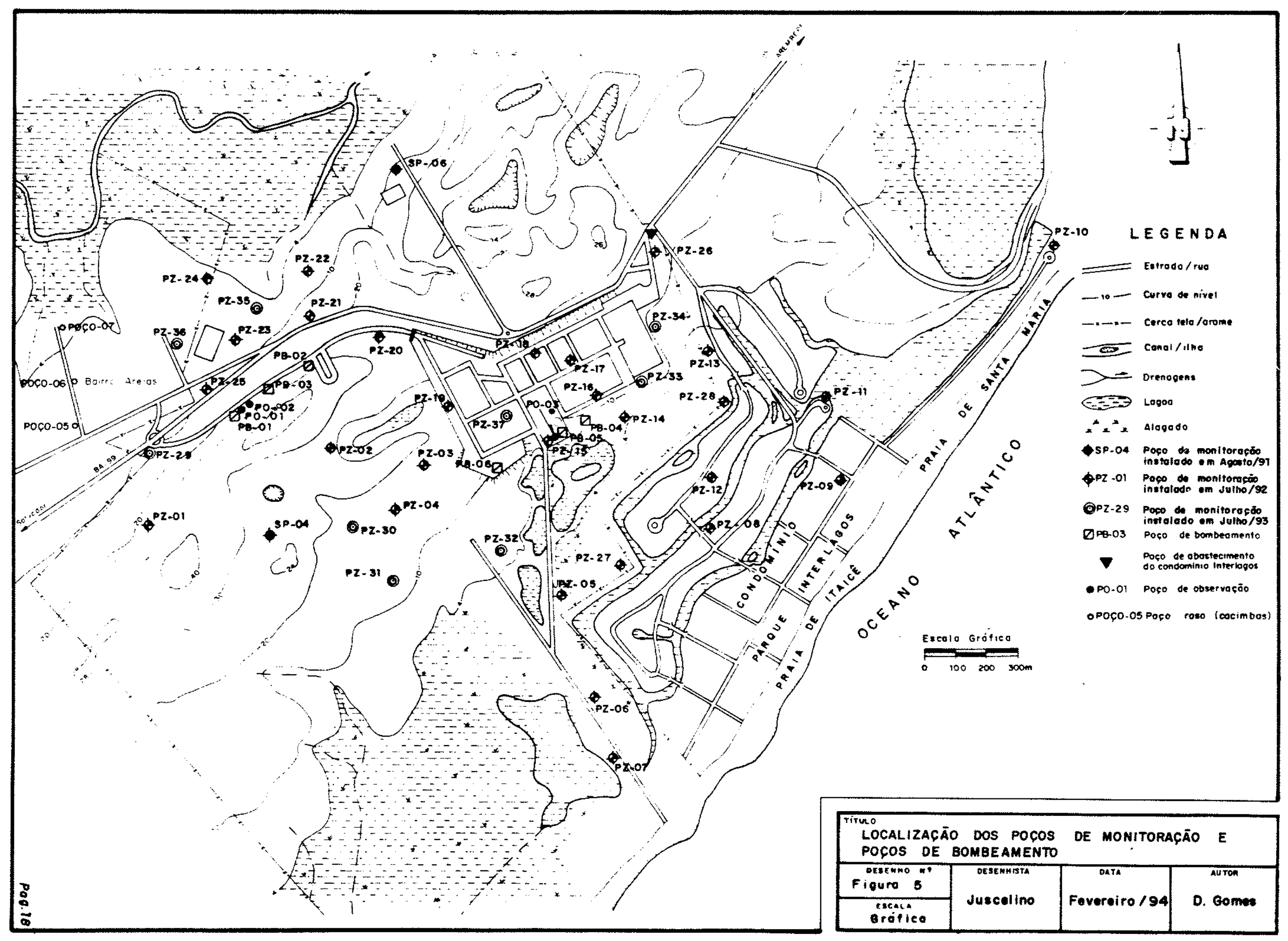




\subsubsection{Poços de Bombeamento e de Observação}

Foram instalados 6 poços para bombeamento das águas subterrâneas, como parte do sistema de remediação global da área.

Estes poços foram confeccionados em PVC Geomecânico nervurado com diâmetro nominal de $150 \mathrm{~mm}$, com filtros ranhurados de abertura $0,75 \mathrm{~mm}$ e espessura de parede $12 \mathrm{~mm}$. A Figura 6 mostra o perfil típico (vide localização na Figura 5).

As sondagens, do tipo rotativo destrutivo, foram iniciadas com diâmetro $500 \mathrm{~mm}$ (tubo de boca para sustentação) e terminadas em $310 \mathrm{~mm}$, sendo $o$ espaço anelar preenchido com pré-filtro selecionado (1 - $2 \mathrm{~mm}$ ) até 3 - $4 \mathrm{~m}$ acima do filtro. o espaço restante foi preenchido com bentonita e cimento.

Os filtros foram posicionados nas frações arenosas inferiores, variando de 4 a $12 \mathrm{~m}$ de espessura.

os 4 últimos metros dos poços de bombeamento foram revestidos, já que encontravam-se junto ao antigo solo de alteração muito argiloso do Embasamento Cristalino pré-Cambriano. Este trecho serviu de local para instalação das bombas submersas (câmara de bombeamento), evitando, assim, problemas de cavitação, comuns, quando as bombas situam-se no trecho de filtros.

Devido ao uso de lama bentonitica durante as perfuraçōes, o desenvolvimento dos poços foi feito imediatamente após o término das sondagens, que duraram 1 dia, através de "air-1ift" e sobrebombeamento com bombas submersas, até o desaparecimento dos finos, prevenindo desta forma, a deposição de bentonita nas paredes do furo.

Foram, ainda, instalados 3 poços de observação, para fins de medição de nível em ensaios de bombeamento (PO-01, PO-02 e PO-03), com desenho semelhante aos poços de monitoração. 
Figura 6 - PERFIL TÍPICO DOS POCOS DE BOMBEAMENTO

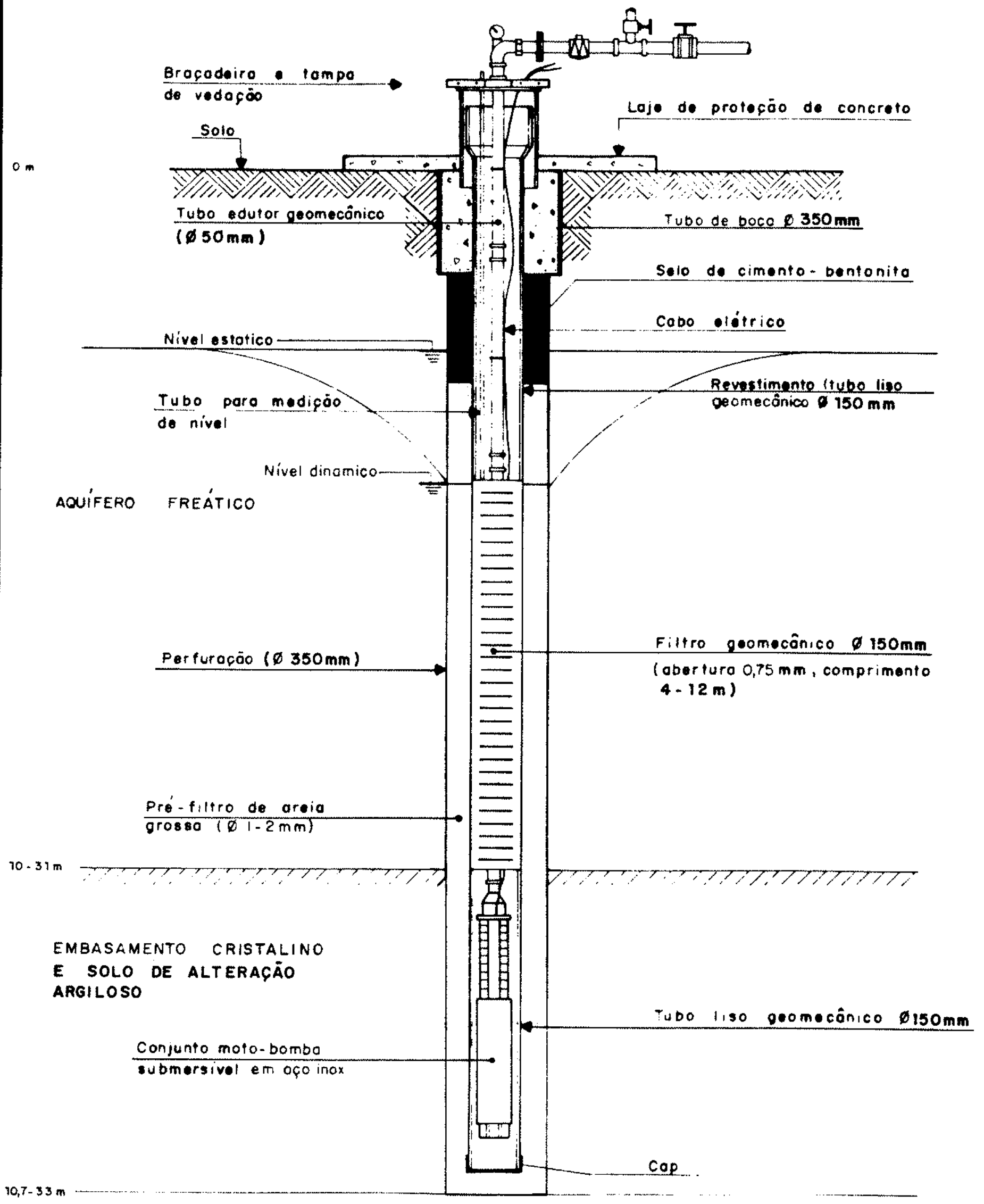




\subsection{ENSATOS HIDROGEOLOGICOS}

\subsubsection{Medidas de Carga Hidráulica e Ensaios de Permeabilidade}

Após a instalação dos poços de monitoração, foi feito o nivelamento topografico dos mesmos pelo processo taqueométrico, com a implantação de poligonal fechada, nivelada analiticamente em relação ao nível médio do mar.

o nivel d'água foi medido antes de cada etapa de amostragem, através de medidor elétrico GRAB \& WILDI, com precisão de $0,5 \mathrm{~cm}$, sendo posteriormente calculada a carga hidráulica, pela diferença entre a cota do poço de monitoração e a distância ao nível d'água, servindo de base para a confeç̧ão dos mapas potenciométricos, para a determinação do sentido do fluxo subterrâneo.

Os ensaios de permeabilidade foram feitos através de dois métodos:

- Ensaio a carga variável ("Bail Test"): mede-se a recuperação do nivel d'água após remoção de um determinado volume d'água do poço. Seguiu a metodologia descrita por HVORSLEV (1951, in FREEZE \& CHERRY, 1979), onde:

$$
K=\frac{r^{2} \ln (L / R)}{2 L T O}
$$

onde :

$K=$ condutividade hidráulica $(\mathrm{m} / \mathrm{s})$

$\boldsymbol{r}=$ raio do poço de monitoração

$R$ = raio do poço de monitoração no trecho ensaiado (m)

$L=$ comprimento do filtro $(m)$

To = tempo para recuperação de 67 \& do nível d'água original (s) 
o valor to é obtido graficamente a partir de curvas H-h/H-Ho $x$ Tempo (min) em papel monolog, onde:

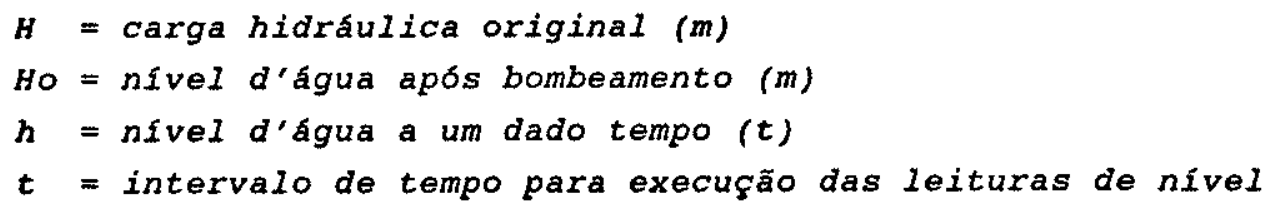

As medições foram feitas a cada minuto, até a estabilização do nivel d'água.

- Vazão constante : em poços com recuperação muito rápida, adotam-se a metodologia de HoLtING (1984), onde:

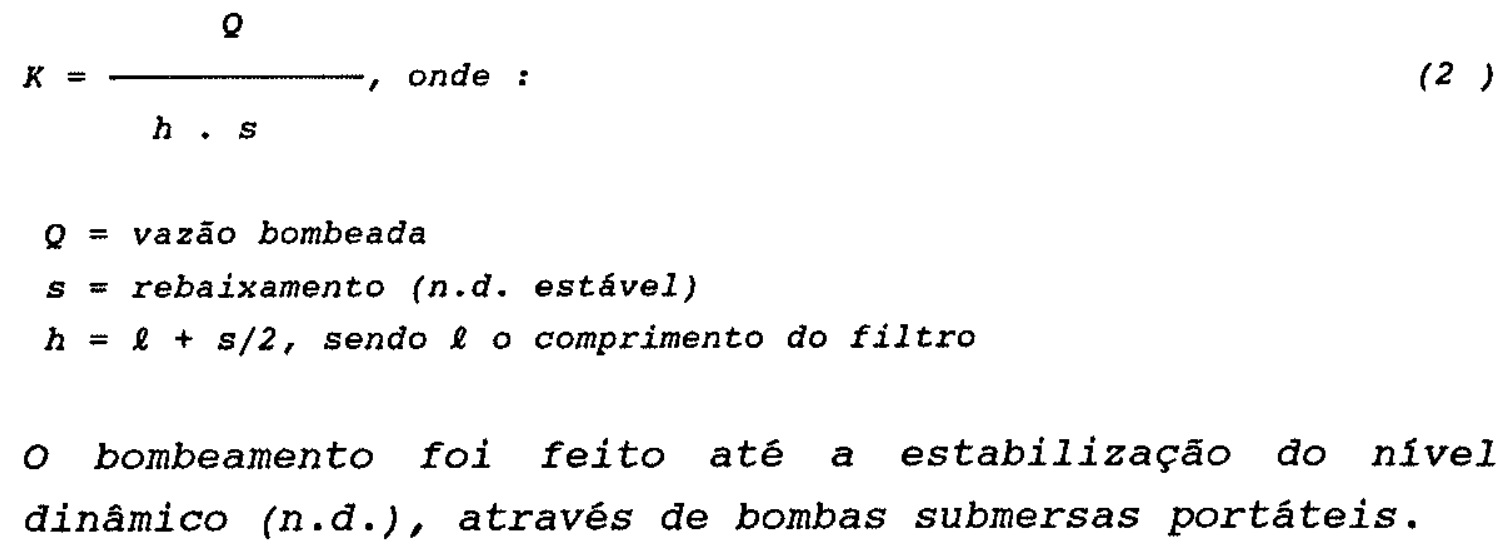




\subsubsection{Ensaios de Bombeamento}

Foram realizados dois tipos de ensaios:

- ensaios de aquifero: visam determinar parâmetros hidráulicos do aquifero, principalmente transmissividade (T) e coeficiente de armazenamento (S). Foram realizados dois ensaios deste tipo, com vazões constantes de bombeamento nos poços de bombeamento $P B-01$ e $P B-05$ e medição de nivel nos poços de observação próximos (respectivamente PO-01 e 02 e PO-03 e PZ-15), assim como nos próprios poços de bombeamento. As leituras foram feitas a cada minuto até 10 min, passando a cada $2 \mathrm{~min}$ (até $20 \mathrm{~min}$ ), $5 \mathrm{~min}$ (até 100 min), $20 \mathrm{~min}$ (até $5 \mathrm{hs}$ ) e a cada hora, até o fim dos testes, de 48 hs para $O P B-01$ e 24 hs para $\circ$ PB-05. A recuperação do nivel também foi medida, em intervalos de $1 \mathrm{~min}$.

- ensaios de poço: realizados em quatro poços, para verificar a vazão ótima (PB-01, 04, 05 e 06). Foram estipuladas três vazões de teste, medindo-se os respectivos niveis dinâmicos. $A$ interpretação foi feita através de gráficos $s x Q$. Os poços $\mathrm{PB}-02$ e 03 apresentaram vazões muito pequenas e, por isso não foram feitos os ensaios. 


\subsection{AMOSTRAGEM E ANÁLISE QUTMICA DE ÁGUAS}

Foram feitas 5 campanhas de coleta e analise quimica de aguas subterrâneas e superficiais: agosto de 1992 ; janeiro, maio, julho e novembro de 1993, através da seguinte metodologia:

- Remoção da água estagnada e medição de nível nos poços de monitoração: previamente às amostragens foi feita a leitura do nivel d'água e removidos 3 vezes o volume a'água existente nos poços de monitoração, visando permitir a entrada de águas representativas do aquifero, sem os efeitos de estagnação (FOSTER \& GOMES, 1989), utilizando-se bombas submersas tipo WHALES Supersub 88/89, feitas em plástico ABS e hélice de aço inoxidável.

- Coleta, preservação e armazenamento: a coleta foi feita através de amostrador tipo caçamba em aço inoxidável 314, com válvula de teflon, previamente limpo com detergente não-fosfatado e água destilada e seco em estufa por 24 hs. As amostras de água superficial foram tomadas em pontos e profundidades distintas, formando amostras compostas das regiões de interesse. A transferência aos frascos de coleta foi feita procurando evitar ao máximo a turbulência e contato com o ar para evitar a precipitação de metais.

A preservação das amostras foi feita de acordo aos parâmetros analisados. 
Para os metais pesados, as amostras eram primeiramente filtrados em membrana $(0,45 \mu \mathrm{m})$, depois acidificadas quando necessário ( $\mathrm{HNO}_{3}$ ou $\mathrm{HCl}$ ) a $\mathrm{pH}<2$ e preservadas em gelo $\left(4^{\circ} \mathrm{C}\right.$ ) até o envio aos laboratórios. Amostras para determinação de Carbono orgânico Dissolvido também foram acidificadas $\left(\mathrm{H}_{2} \mathrm{SO}_{4}\right.$ até $\left.\mathrm{pH}<2\right)$ e refrigeradas. As amostras para sulfeto foram conservadas com adição de 1 me de acetato de $\mathrm{Zn}$ ( $\mathrm{pH} 6$ a 9), as para $\mathrm{N}-\mathrm{NO}_{3}$ foram acidificadas $\left(\mathrm{H}_{2} \mathrm{SO}_{4}, \mathrm{pH}<2\right)$, assim como para bleos e graxas (frasco de vidro $\mathrm{HCl}, \mathrm{pH}<2$ ). Amostras para sulfato, nitrito e cloreto foram apenas refrigeradas, seguindo recomendações de CETESB (1988).

A primeira campanha de analises quimicas envolveu as seguintes determinaçōes: ferro solúvel, manganês, cromo hexavalente, vanádio, aluminio, titânio, zinco, cobre, chumbo, sulfato, sulfeto, cloreto, nitrato, nitrito, carbono orgânico dissolvido e óleos e graxas (enviadas ao laboratório da TCA - Empresa de Apoio Tecnológico e Consultoria Ambiental, em São Paulo); além de Nióbio, feita na GEOLAB-Divisão de Laboratórios de GEOSOL, em Belo Horizonte.

No campo, foram ainda medidos o $\mathrm{pH}$, com papel indicador ou $\mathrm{pH-}$ metro, condutividade elétrica (condutivimetro WTW-LF91) e temperatura.

As demais campanhas analisaram em laboratório apenas sulfato e ferro solúvel, além das determinaçōes "in situ".

A segunda campanha foi analisada no laboratório da CEPED, em Salvador, $B A$ e as demais campanhas nos laboratórios da própria TIBRĂS.

Todas as análises seguiram as metodologias do standard Methods, 1985. 


\section{APRESENTAÇÃO E DISCUSSÃO DE RESULTADOS}

\subsection{HIDROGEOLOGIA REGIONAL}

A nivel regional, a área de estudo situa-se no contexto geral da Bacia Sedimentar do Recôncavo $\left(10.000 \mathrm{Km}^{2}\right)$ de idade Eocretácea e cuja origem está diretamente ligada à separação dos continentes africano e sul-americano, ocupando a porção sul do Graben da Bahia, com $56.000 \mathrm{Km}^{2}$ de área e espessuras de 3.000 a $8.000 \mathrm{~m}$ (REBOUÇAS, 1990).

Os sedimentos desta Bacia (Figura 7) foram depositados numa fossa tectônica formada nas rochas pré-Cambrianas do cráton do são Francisco, em ambiente flúvio-lacustre, a partir de Neojurássico.

Estratigraficamente, estes sedimentos formam o supergrupo Bahia (K), composto pelas Formaçōes São Sebastião, (Cretáceo inferior) e Marizal (Cretáceo superior). A primeira é composta por intercalações de arenitos vários com lentes de folhelhos e siltitos (Figura 8).

A Formação Marizal assenta-se discordantemente sobre a Fm. São Sebastião, sendo formada por um conglomerado basal e arenitos imaturos variegados e lentes irregulares de argilas e siltes.

A espessura destas formaçōes é superior a $1.000 \mathrm{~m}$ (REBOUÇAS, 1990).

- Aquifero São Sebastião representa o principal aquifero regional, desempenhando um importante papel tanto no suprimento de água potável às indústrias do Complexo Petroquímico de Camaçari (COPEC), como na regularização da vazão dos rios locais, principalmente rio Joanes e Jaculpe, cuja contribuição foi estimada em $40 \mathrm{~m}^{3} / \mathrm{s}$ (REBOUÇAS, 1990), rios estes que abastecem a cidade de salvador. 
Poços perfurados na área da COPEC costumam chegar a $300 \mathrm{~m}^{3} / \mathrm{h}$, com capacidades especificas variando entre 1 a $30\left(\mathrm{~m}^{3} / \mathrm{h}\right) / \mathrm{m}$. Segundo REBOUÇAS (1990), cerca de 200 poços foram perfurados nesta área, estando cerca de 100 em uso, com profundidades entre 57 e $450 \mathrm{~m}$.

o padrão regional de fluxo se dá em sentido ao mar (NW-SE), sendo "bloqueado" junto ao Oceano Atlântico, devido ao "horst" préCambriano (Figura 7), provocando uma zona de descarga junto à Falha de Salvador e rio Capivara Grande (limite oeste da área de estudo, vide Figura 2).

Acima da Fm. Marizal, ocorrem os sedimentos arenosos da Fm. Barreiras, de idade Terciária, formando "tabuleiros" com cerca de 30 a $40 \mathrm{~m}$ de espessura e sedimentos quaternários de distribuição mais restrita e reduzida espessura. Estes depósitos ocorrem junto à linha costeira, sob a forma de sedimentos areno-argilosos, por vezes orgânicos, nas planicies aluviais dos rios e de areias inconsolidadas em dunas semi-móveis com pouca cobertura vegetal.

Estas formaçōes constituem aquiferos em geral de pouca produtividade, porém em muitas áreas rurais e peri-urbanas podem constituir-se nas unicas fontes de água potável para a população, através de poços escavados (cacimbas) ou mesmo poços tubulares de pequena profundidade.

A precipitação na região de Camaçari apresentou valores históricos (1961 a 1990) de $1980 \mathrm{~mm} / \mathrm{a}$, e evapotranspiração de $1354 \mathrm{~mm} / \mathrm{a}$, o que faz prever taxas de recarga elevadas, da ordem de $430 \mathrm{~mm} / \mathrm{a}$, considerando-se escoamento superficial em torno de 10 \% da precipitação.

o clima local é tropical úmido com duas estações bem marcadas: estação seca, de agosto a fevereiro e estação chuvosa, de março a julho, conforme mostra a Figura 9. 
Figuro 7 - LOCALIZAÇĀO DA BACIA DO RECÔNCAVO
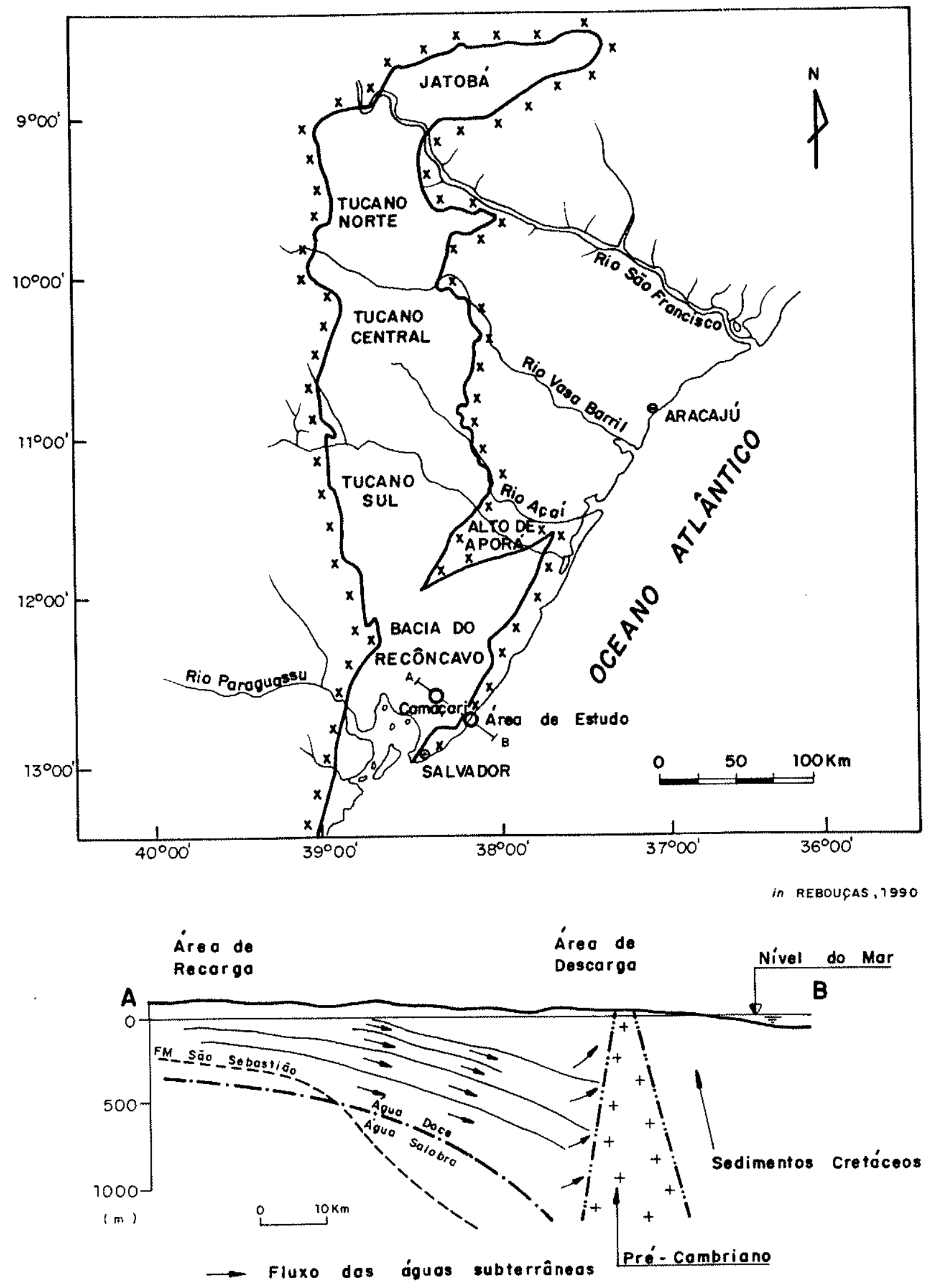

Pag. 28 
Fig. 8 - MAPA GEOLÓGICO REGIONAL

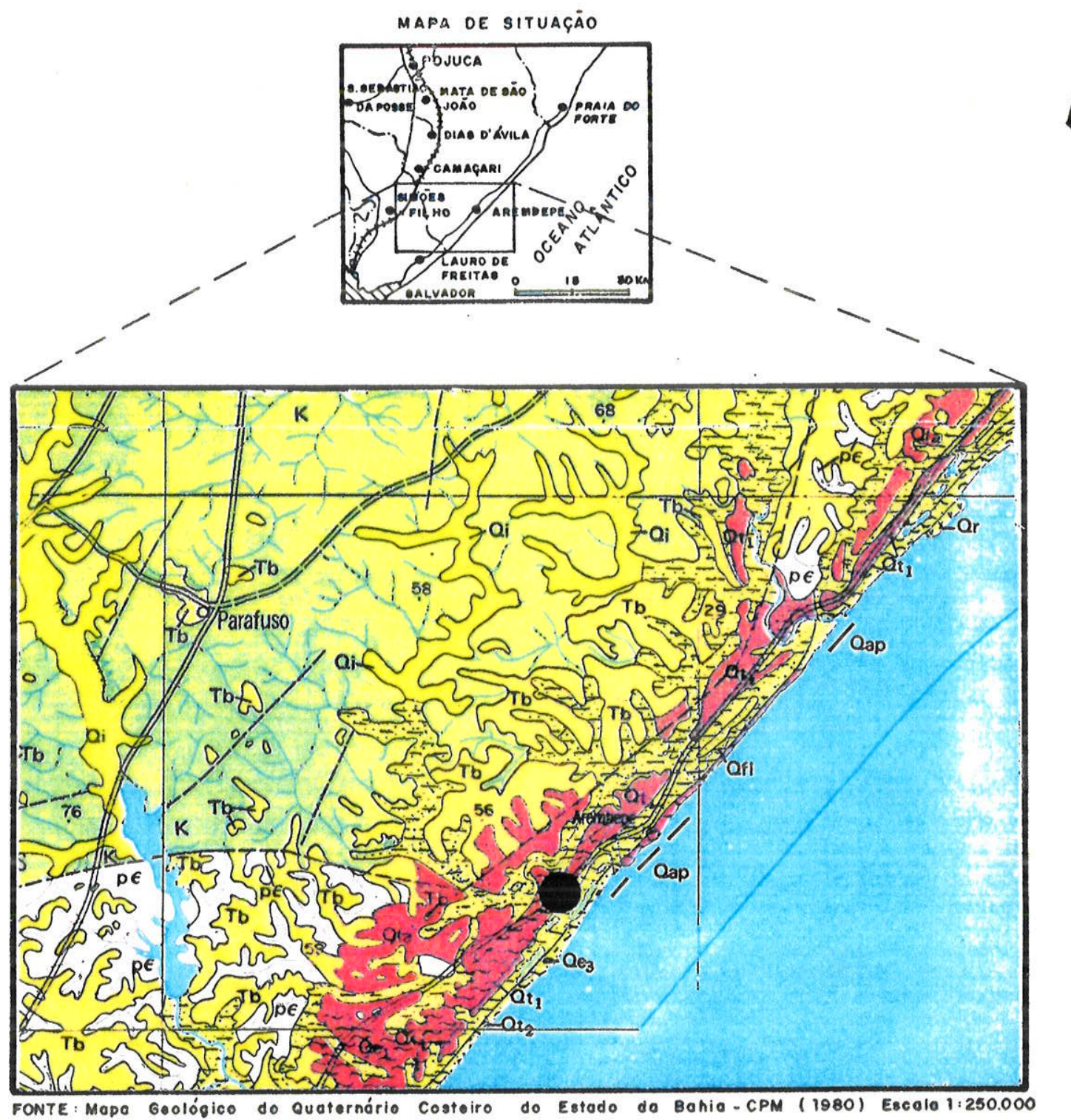

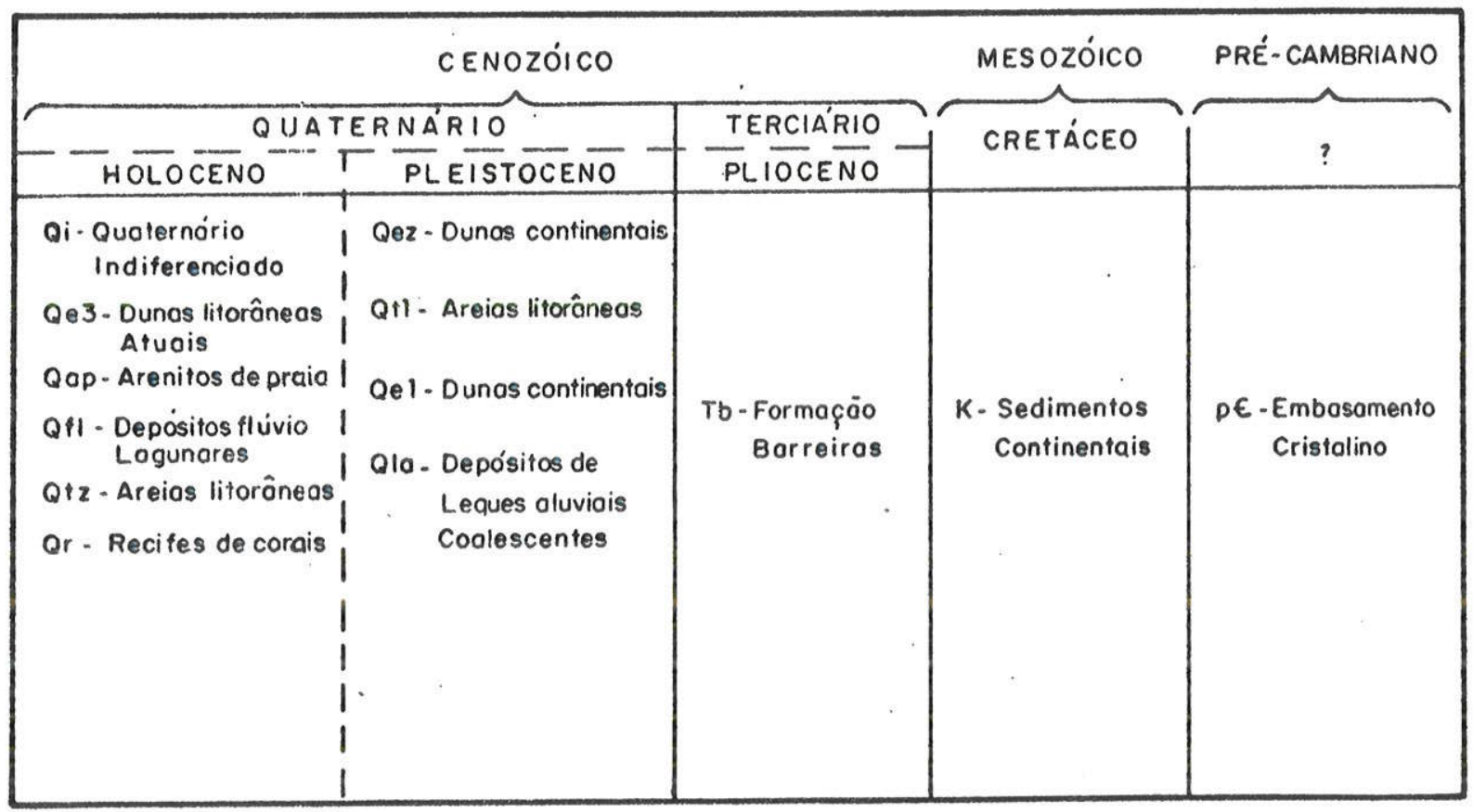




\section{FIGURA 9: DADOS CLIMATOLÓGICOS}

REGIĀO DE CAMAÇARI (1961-1990)

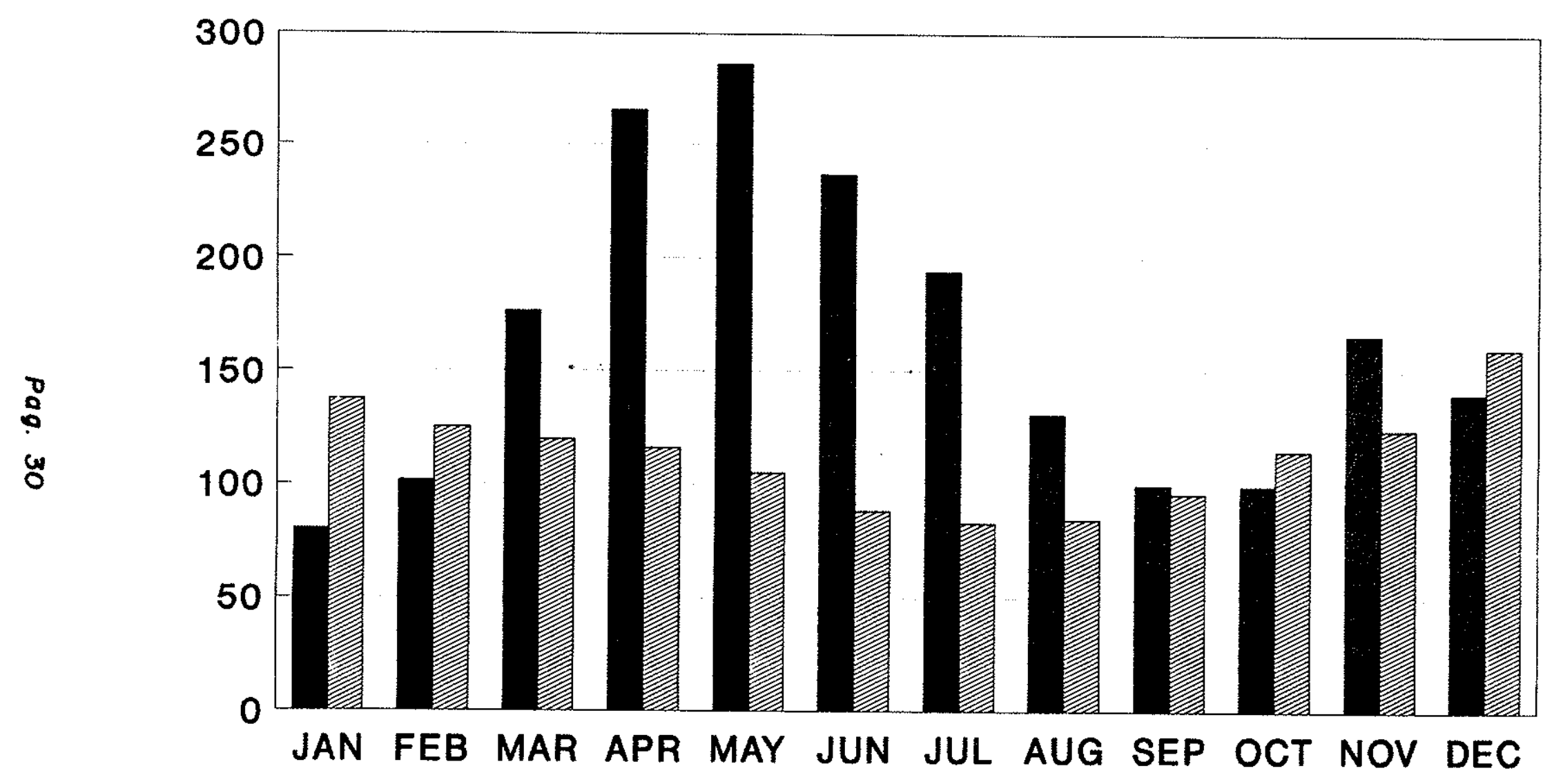

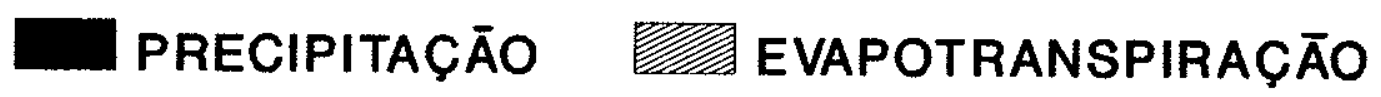

VALORES MÉDIOS (mm) 


\subsection{HIDROGEOLOGIA LOCAL}

\subsubsection{Aquiferos e Niveis Semi-Confinantes}

A área de estudo situa-se junto à costa, onde afloram sedimentos quaternarios aluviais e areias de dunas, assentados discordantemente sobre o embasamento cristalino pré-Cambriano.

A Figura 10 mostra a localização das seções hidrogeológicas $A-A^{\prime}$ (Figura 11), $B-B^{\prime}$ (Figura 12), $C-C^{\prime}$ (Figura 13), $D$ - $D^{\prime}$ (Figura 14) e $E-E^{\prime}$ (Figura 15).

Acima do embasamento cristalino gnáissico ou granulftico, ocorre uma camada de 1 a $4 \mathrm{~m}$ de espessura, composta por argilas e areias finas silto-argilosas, localmente com grânulos angulosos, provavelmente correspondendo ao antigo solo de alteração da rocha.

Sobre esta camada, em contato erosivo, situa-se um pacote mais espesso $(5-10 \mathrm{~m})$ de areias finas bem selecionadas, por vezes ricas em matéria orgânica (cor preta) ou cimentadas por óxidos de ferro, inclusive ocorrendo crostas limoniticas esporádicas. Lentes argilosas orgânicas delgadas $(1-2 m)$ também ocorrem localmente.

Por $f i m$, recobrindo as camadas inferiores, ocorrem areias brancas finas a médias, muito bem selecionadas, formando uma espessa duna $(20$ - $30 \mathrm{~m})$, localizada aproximadamente à metade da área de estudo, com direção $N E$, onde foram depositados os residuos industriais.

A espessura da zona não-saturada varia de 10 - $17 \mathrm{~m}$ na área das dunas a menos de $1 \mathrm{~m}$ junto às baixadas, onde afloram as areias e argilas orgânicas tipicas de zonas alagadiças. 
Estas litologias compōem um unico aquifero de caráter livre, relativamente heterogêneo, com espessura saturada variando entre 7 e $14 \mathrm{~m}$, aproximadamente, podendo apresentar efeitos de semiconfinamento localizados. 


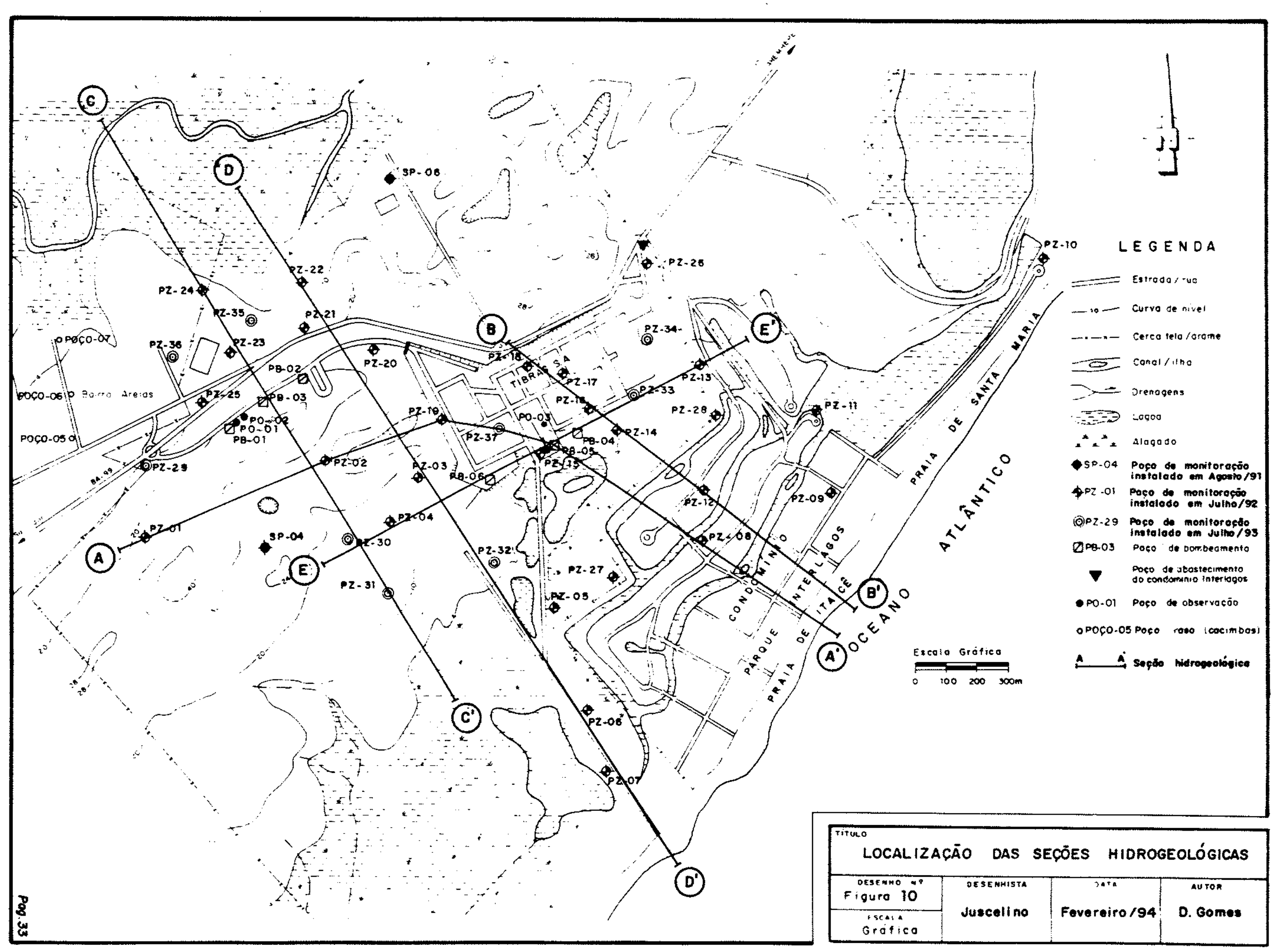



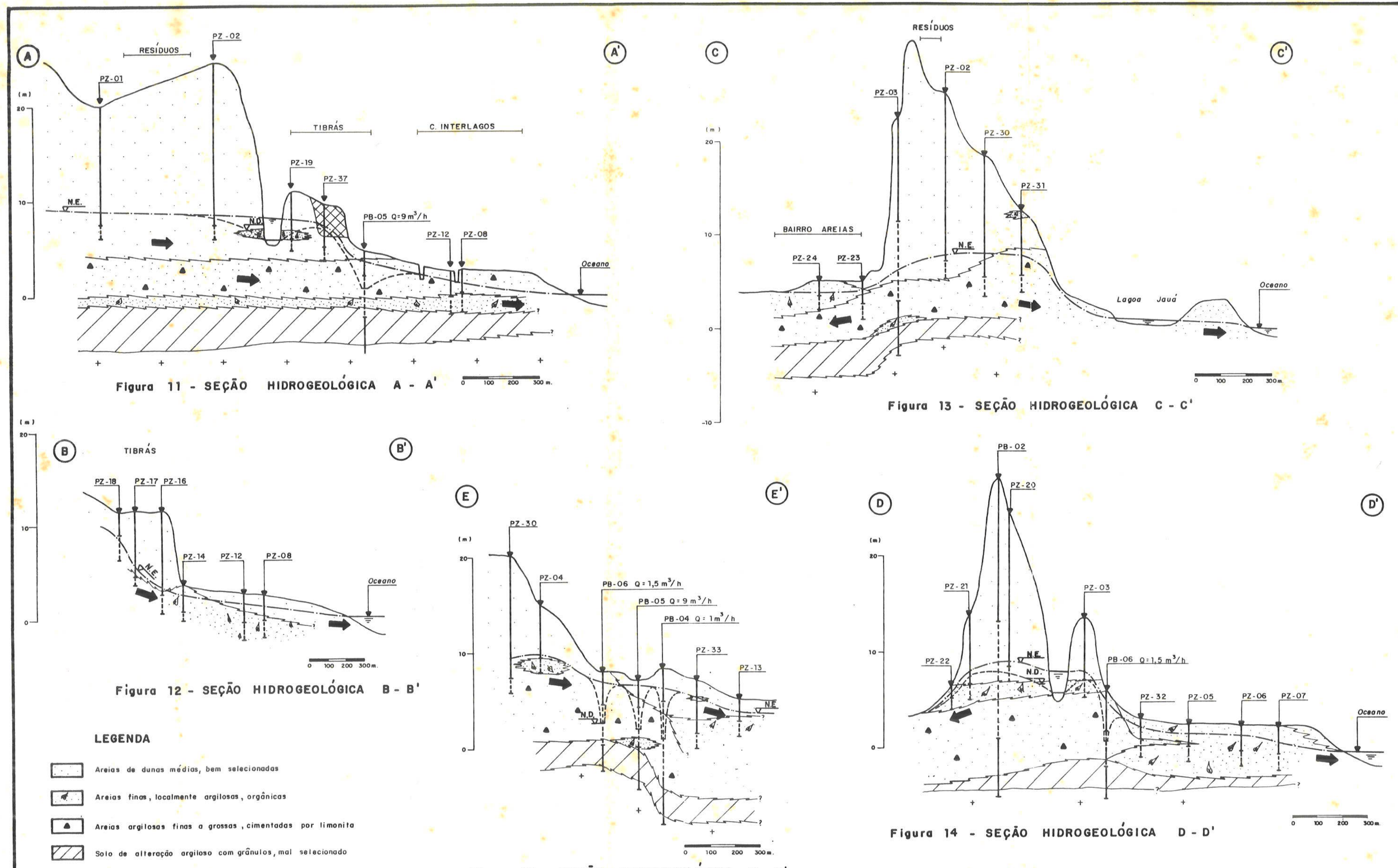

Figura 15 - SEÇĀO HIDROGEOLÓGICA E- E'

OBS. Exagero vertical aproximado : 50 vezes 


\subsubsection{Velocidade e Sentido de Fluxo}

o padrão geral de fluxo se dá dos altos topográficos (zona de recarga) para as áreas alagadiças e para o oceano atlântico, conforme mostra o Mapa Potenciométrico (Figura 16).

As diferenças de nivel d'água entre épocas de seca e chuvas não são expressivas (até $0,5 \mathrm{~m}$ ), a ponto de alterar o padrão de fluxo geral. A Figura 17 mostra o efeito do bombeamento da lagoa situada entre as dunas como parte do sistema de remediação do aquifero.

A Tabela 2 mostra os valores calculados de condutividade hidráulica para os piezômetros segundo as litologias encontradas.

As velocidades de escoamento típicas para as regiōes estudadas, segundo a Lei de Darcy, são:

- Bairro Areias (NW): 4 a $210 \mathrm{~m} / \mathrm{a}$ (gradiente hidráulico (i) variando entre 0,05 e 0,001 ; porosidade efetiva para fluxo nef $=3 \%$ condutividade hidráulica média $\left.K=4 \times 10^{-5} \mathrm{~m} / \mathrm{s}\right)$.

- Condominio Interlagos (SE): $63 \mathrm{~m} / \mathrm{a} \quad(i=0,001$; nef $\left.=3 \% ; K=6 \times 10^{-5} \mathrm{~m} / \mathrm{s}\right) ; e$

- Area Industrial: $690 \mathrm{~m} / \mathrm{a}(1,9 \mathrm{~m} / \mathrm{d}) ; i=0,01 ;$ nef $=15 \mathrm{o}$; $K=3,3 \times 10^{-4} \mathrm{~m} / \mathrm{s}$. Esta elevada velocidade está associada ao gradiente relativamente alto, provavelmente ocasionado por perdas na rede de água da fábrica, além do fato do solo haver sido aterrado com sedimentos arenosos das dunas próximas. Desta forma, esta velocidade é válida para a porção mais superficial do aquifero. 


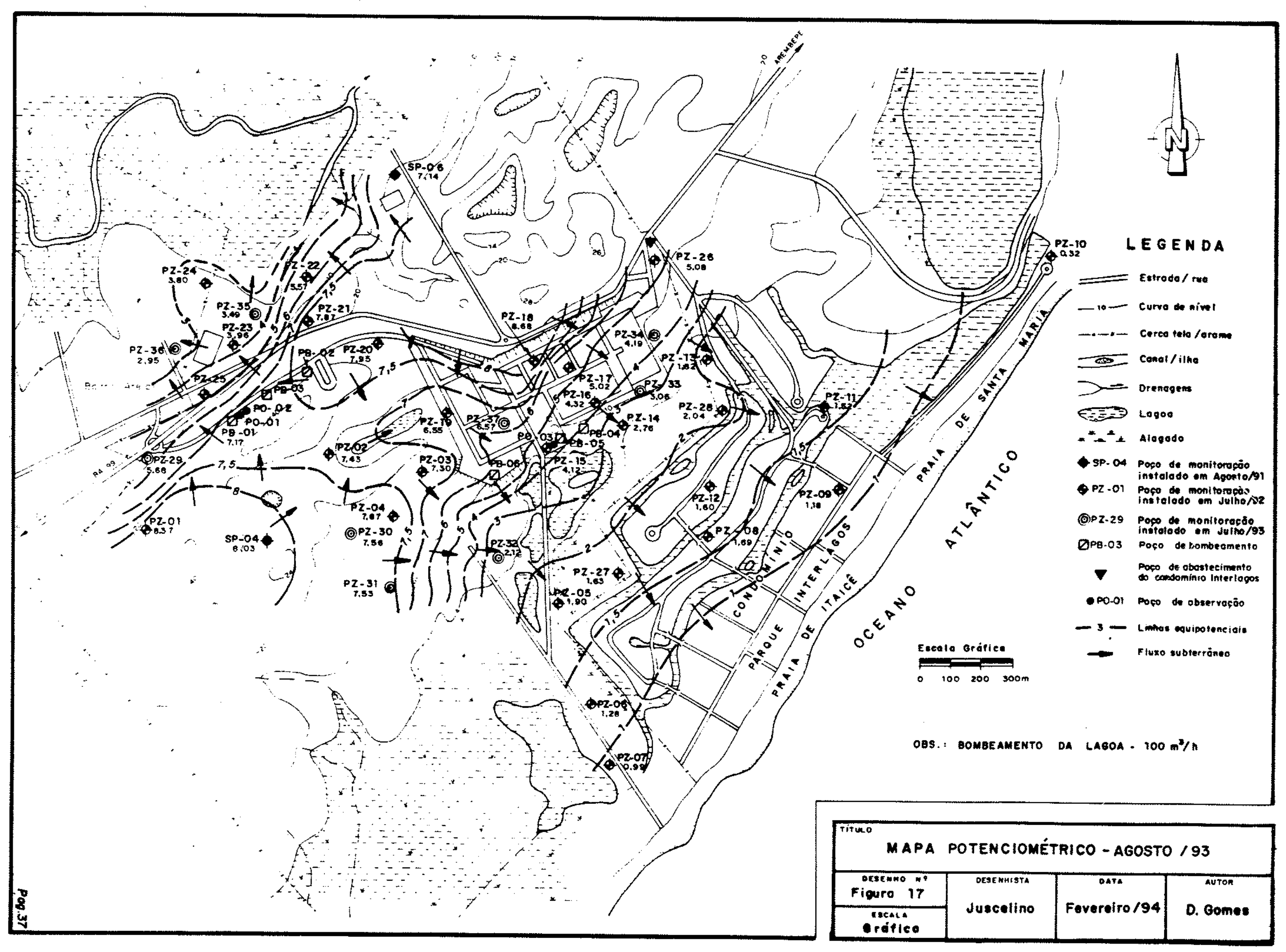




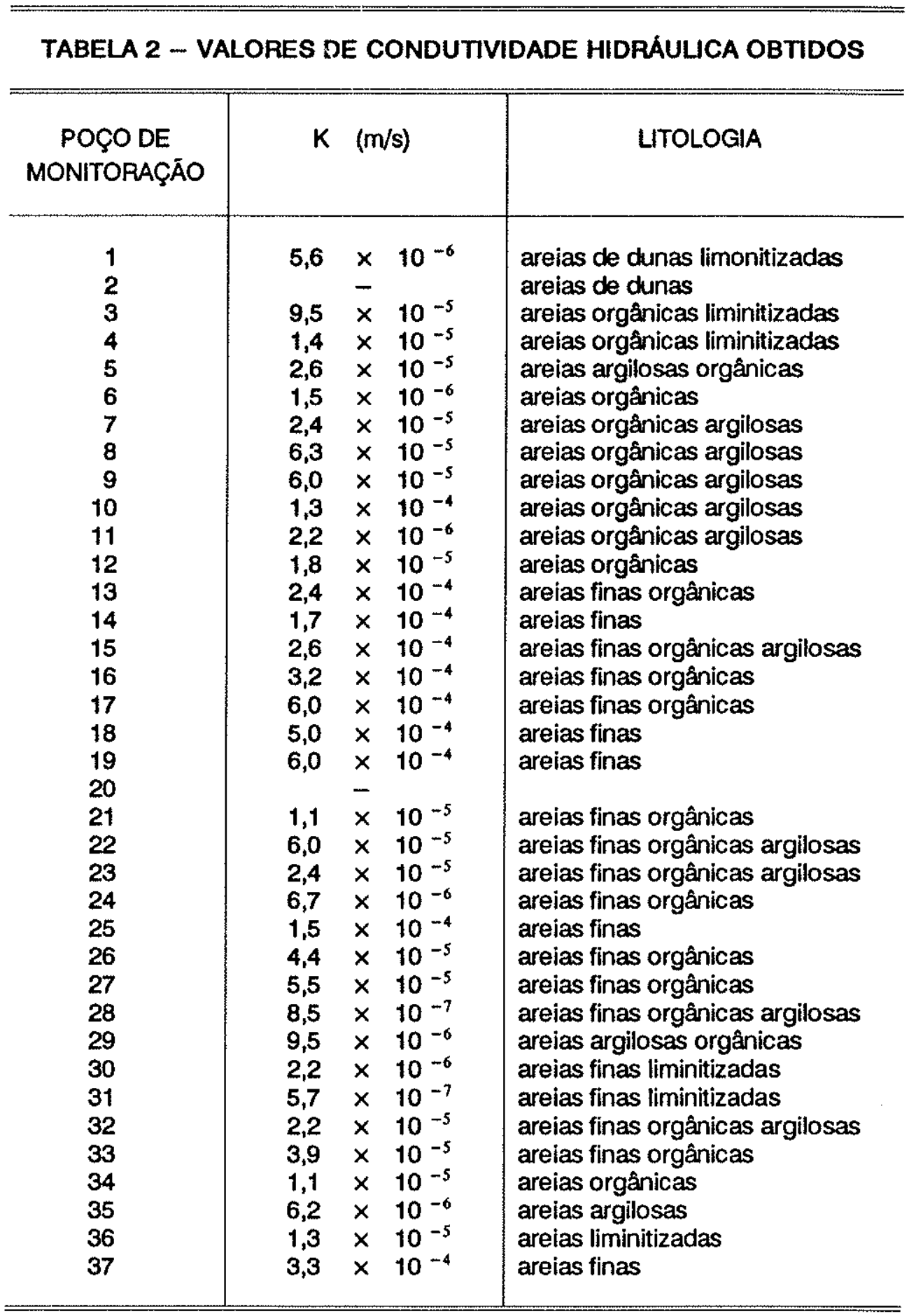

média $=1,12 \times 10^{-4}$ 


\subsubsection{Parâmetros Hidrodinâmicos}

A execução dos ensaios de bombeamento permitiu o cálculo de transmissividades, coeficiente de armazenamento e permeabilidades para os poços de bombeamento.

A interpretação dos dados de rebaixamento $x$ tempo foi feita através do método de comparação com as seguintes curvas tipo:

- THEIS (1935, in MANDEL \& SHIFTAN, 1981) (POÇO PB-05):

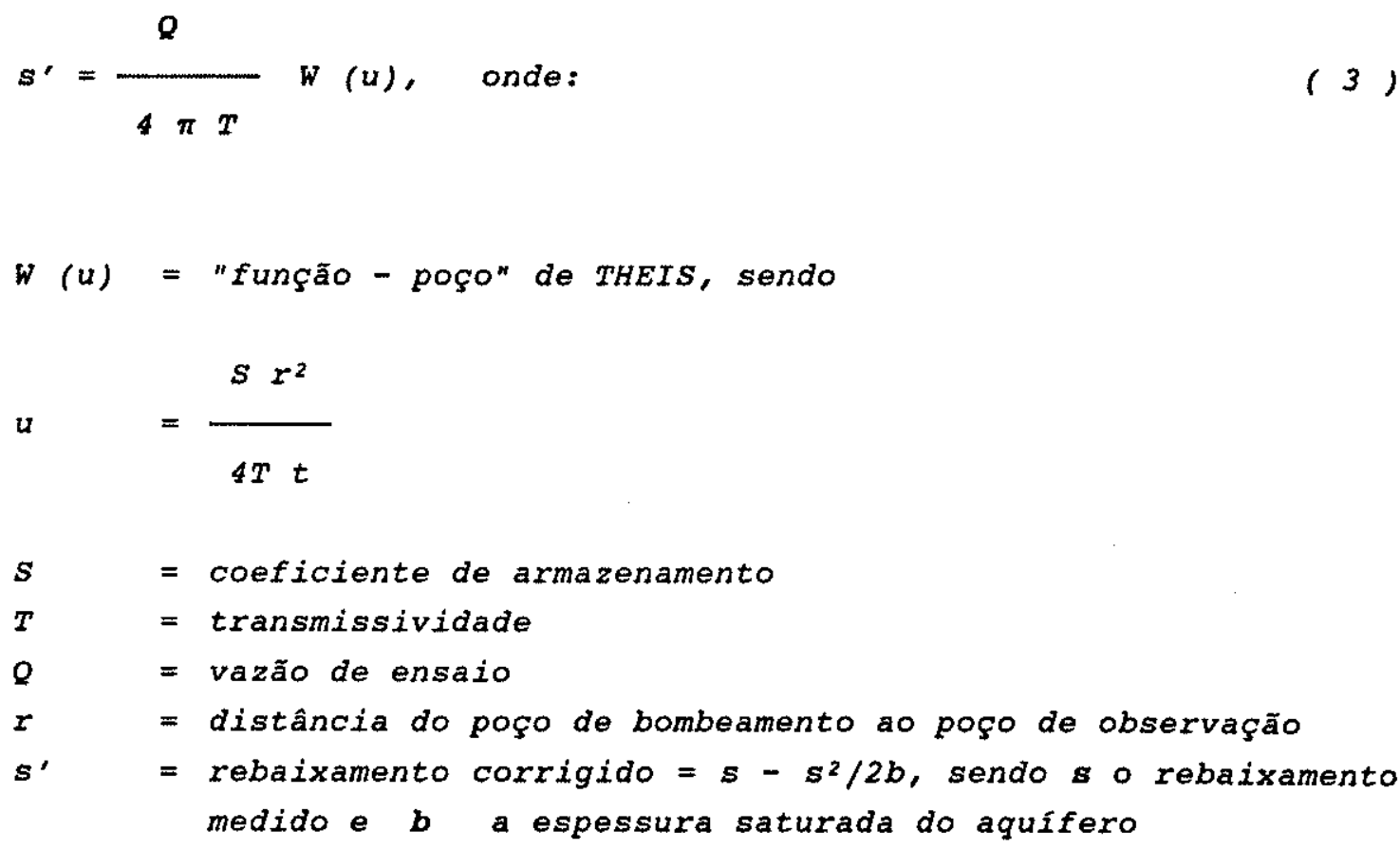

A correção do rebaixamento visa eliminar as diferenças de transmissividade que ocorrem em aquiferos freáticos quando rebaixados (MARSILY, 1986). 
- HANTUSH (1956, in MANDEL \& SHIPTAN, 1981) (POÇO PB-01):

$$
\begin{aligned}
& s=\frac{Q}{4 \pi T} W(u, r / B), \text { onde: } \quad(4)
\end{aligned}
$$

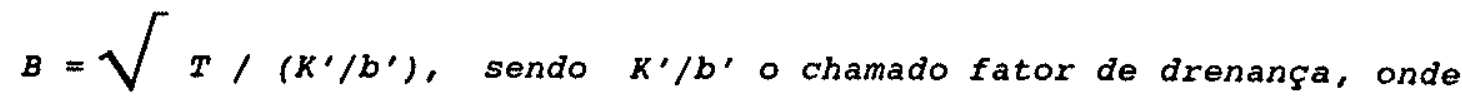

$$
\begin{aligned}
& K^{\prime}=\text { condutividade hidráulica do nivel } \\
& \text { semi-confinante e } b^{\prime} \text { sua espessura. }
\end{aligned}
$$

Esta solução é indicada para aquiferos semi-confinados e foi aplicada ao poço $P B-01$ devido à presença de uma pequena camada semi-confinante argilosa.

Além das comparaçōes com curvas-tipo, foi usado o método da aproximação logarítima de JACOB (1950, in MANDEL \& SHIFTAN, 1981), para fim de comparação.

Curvas de recuperação foram interpretadas através do método de THEIS para este tipo de ensaio, em gráfico monolog.

Além destes métodos, as condutividades hidráulicas foram calculadas para todos os poços de bombeamento, utilizando a fórmula de Du puit (in MARSILY, 1986).

Os resultados encontram-se na Tabela 3, incluindo os raios máximos de influência, segundo SICHARD (in MOTOR COLUMBUS, 1987). As curvas tempo $x$ rebaixamento podem ser vistas nas Figuras 18 (PB-01) e 19 (ensaio no Pb-05; leituras no poço de observação PO-03).

o ensaio no poço PB-05 mostrou a influência das lagoas próximas no inicio do teste, mantendo o nivel do poço estável temporariamente, fato que pode ser visto na Figura 19. 


\begin{tabular}{|c|c|c|c|c|c|c|c|c|c|}
\hline \multirow{2}{*}{ POCo } & \multicolumn{6}{|c|}{ TRANSMISSIMDADE $\left(\mathrm{m}^{2} / \mathrm{s}\right)$} & \multirow{2}{*}{$\begin{array}{c}\text { COEFICIENTE } \\
\text { ARMAZENAMENTO } \\
\text { (\%) }\end{array}$} & \multirow{2}{*}{\multicolumn{2}{|c|}{$\begin{array}{l}\text { PAIO }(\mathrm{m}) \\
\text { MAX. INFLUENCIA } \\
\text { SICHAFD }\end{array}$}} \\
\hline & THEEIS & JACOB & HANTUSH & $\begin{array}{l}\text { THE्यS } \\
\text { recup. }\end{array}$ & $\begin{array}{c}\text { DU PUIT } \\
T=K b \\
(1)\end{array}$ & MEDIA & & & \\
\hline \multirow{4}{*}{$\begin{array}{l}P B-01 \\
P B-02 \\
P B-03 \\
P B-04\end{array}$} & \multirow{6}{*}{$3,5 \times 10^{-3}$} & \multirow[t]{4}{*}{$2,3 \times 10^{-3}$} & \multirow[t]{6}{*}{$B \times 10^{-3}$} & \multirow[t]{4}{*}{$7,3 \times 10^{-6}$} & $4.7 \times 10^{-5}$ & $2.3 \times 10^{-3}$ & \multirow[t]{4}{*}{3,5} & 36 & $\left(0,96 \mathrm{~m}^{3} / \mathrm{m}\right)$ \\
\hline & & & & & $6,9 \times 10^{-6}$ & $6,9 \times 10^{-6}$ & & 15 & $\left(0.22 \mathrm{~m}^{3} / \mathrm{h}\right)$ \\
\hline & & & & & $5,2 \times 10^{-6}$ & $5,2 \times 10^{-6}$ & & 15 & $\left(0,12 \mathrm{~m}^{3} / \mathrm{h}\right)$ \\
\hline & & & & & $1,1 \times 10^{-4}$ & $1,1 \times 10^{-4}$ & & 30 & $\left(1,0 \mathrm{~m}^{3} / \mathrm{h}\right)$ \\
\hline$P B-05$ & & $1,7 \times 10^{-3}$ & & $1,5 \times 10^{-3}$ & $7,4 \times 10^{-4}$ & $1,9 \times 10^{-3}$ & 2 & 120 & $\left(9 \mathrm{~m}^{3} / \mathrm{h}\right)$ \\
\hline$P B-06$ & & & & & $1,1 \times 10^{-4}$ & $1.1 \times 10^{-3}$ & & 45 & $\left(1,5 \mathrm{~m}^{3} / \mathrm{h}\right)$ \\
\hline
\end{tabular}

(1) T calculada a partir do cálculo de $K: Q=1,366 K\left(\mathrm{H}^{2}-h^{2}\right)$. onde $\log R / r$

$K=$ condứnidade hidráulica $(\mathrm{m} / \mathrm{s})$

$H=$ espessura saturada $(m)$

$h=H-s(m)$

8 = rebaixamento (s)

$A=$ distância poço - poço de obsenvação $(m)$

$r=$ rajo do poço $(\mathrm{m})$

(2) $A=3.000 \mathrm{~s} \mathrm{~K}^{1 / 2}$ 


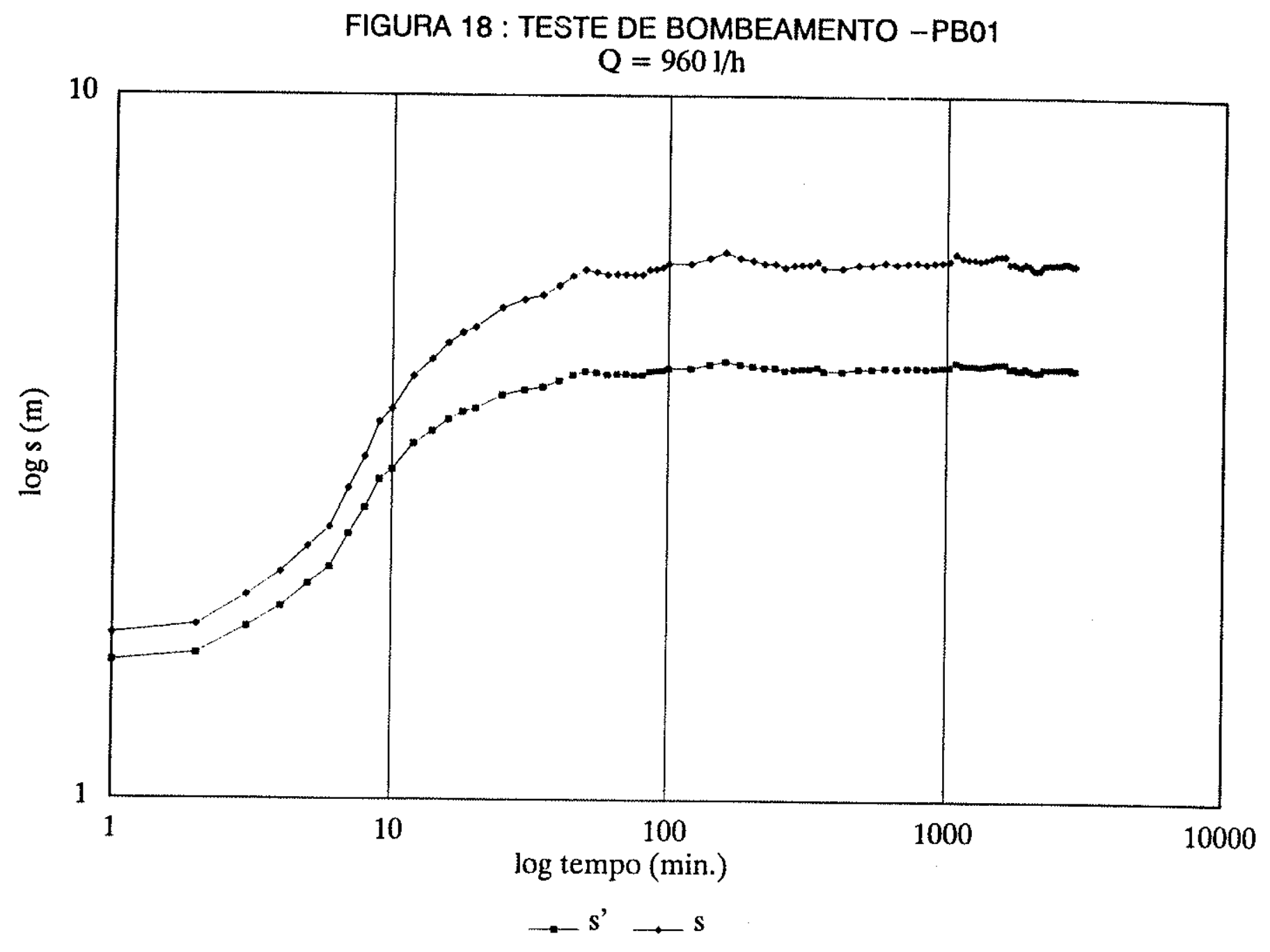

Pag. 42 


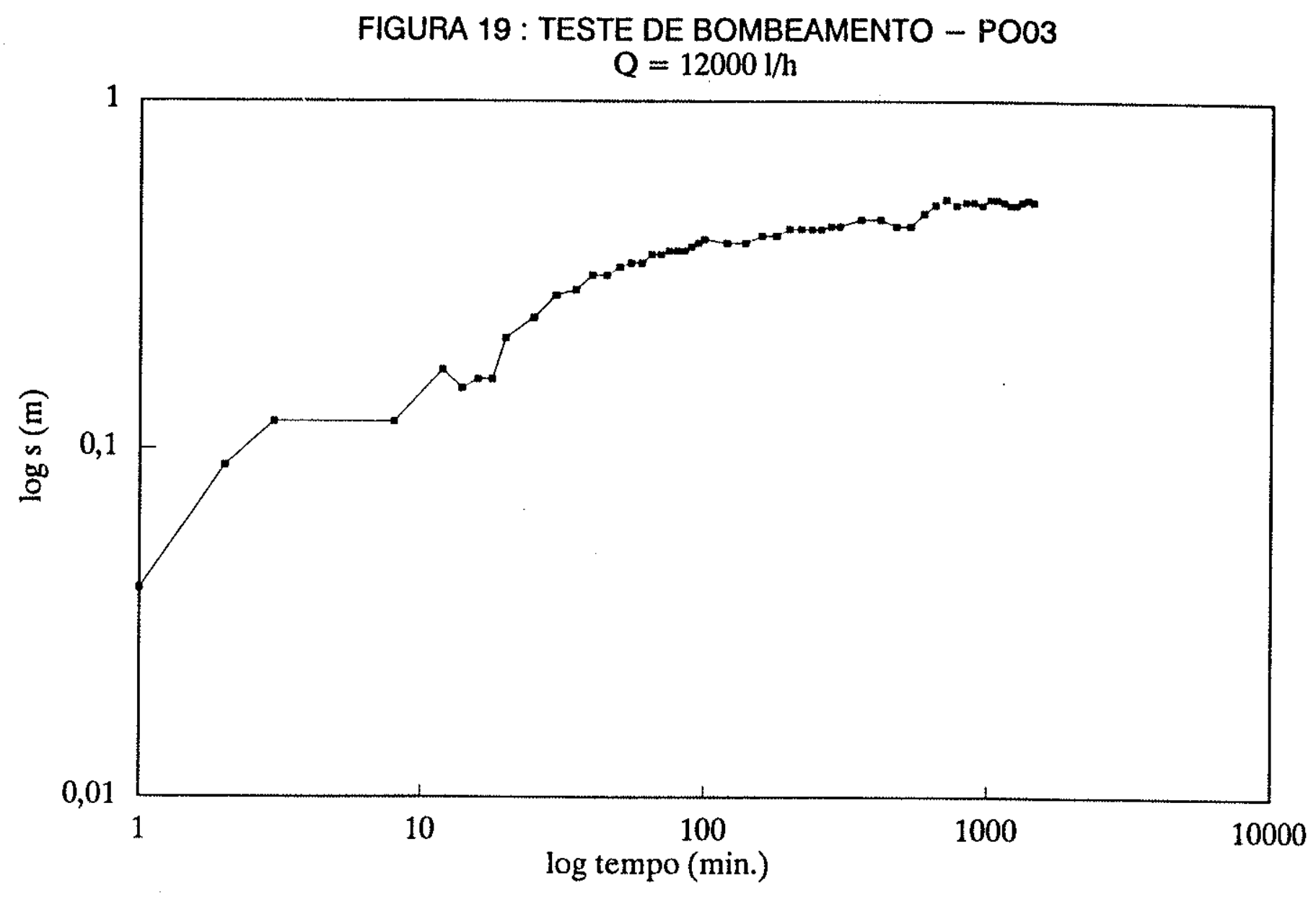

$\rightarrow-s^{\prime}$

obs.: Bombeamento efetuado no PB05 $(\mathrm{R}=8 \mathrm{~m})$ 


\subsection{GEOFISICA}

Os valores de resistividade aparente variaram entre 10 e $14.000 \mathrm{ohm} . \mathrm{m}$, possibilitando a identificação de vărias camadas com propriedades elétricas distintas conforme mostra a Tabela 4.

Apesar da dificuldade de realização nas dunas, devido às altas resistividades das areias secas, as sondagens elétricas permitiram definir o topo rochoso do embasamento cristalino com razoável precisão (Figura 20), posteriormente confirmado pelos poços de bombeamento.

Os valores relativamente baixos para o embasamento cristalino podem ser explicados pelo fraturamento do mesmo e presença de poluição por sais em várias sondagens, sendo em alguns casos dificil a identificação do mesmo, como por exemplo a sondagem SE03 .

o contraste entre as areias orgânicas argilosas e o solo de al teração argiloso não é claro em várias sondagens, especialmente nas áreas poluidas.

o caminhamento elétrico (Figura 21) mostrou anomalias em quatro regiões principais, relacionadas às perdas industriais (I), depósito de resíduos (II e III) e perdas na região do emissário submarino (IV). Valores inferiores a $30 \mathrm{ohm} . \mathrm{m}$ foram considerados anomalias fortes devido à poluição do aquifero freático.

A anomalia a NE é maior do que as plumas de poluição medidas no aquifero, provavelmente devido à presença de areias argilosas orgânicas nesta área.

As anomalias a $N W$ dos residuos se devem à poluição do aquifero por dois focos de residuos (vide Figura 2), migrando em direção a uma drenagem do rio Capivara Grande. 
TABELA 4 - RESULTADOS DAS SONDAGENS ELETFUCAS

\begin{tabular}{|c|c|c|c|}
\hline SEV & $\begin{array}{l}\text { Resistividade } \\
\text { (Ohm.m) }\end{array}$ & $\begin{array}{c}\text { ESPESSURA } \\
(\mathrm{m})\end{array}$ & INTERPRETAÇĀO \\
\hline or & $\begin{array}{r}1900 \\
30 \\
100\end{array}$ & $\begin{array}{l}4,0 \\
6,0\end{array}$ & $\begin{array}{l}\text { areia argilosa seca } \\
\text { areia orgánica argilosa } \\
\text { ombasamento fratura do salgado }\end{array}$ \\
\hline 02 & $\begin{array}{r}3900 \\
300 \\
50 \\
800\end{array}$ & $\begin{array}{r}3 \\
10 \\
5\end{array}$ & $\begin{array}{l}\text { areia argibsa seca } \\
\text { areia argilosa satura da } \\
\text { solo de alteraşán } \\
\text { embasamento cristalino fraturado }\end{array}$ \\
\hline 03 & $\begin{array}{r}120 \\
20 \\
50 \\
200\end{array}$ & $\begin{array}{r}1,5 \\
5 \\
17\end{array}$ & $\begin{array}{l}\text { areia argilosa organica seca } \\
\text { areia salurada muito contaminada } \\
\text { areia saturada pouco contaminada } \\
\text { embasamento cristalino fraturado (contamirado } \eta \text { ) }\end{array}$ \\
\hline 04 & $\begin{array}{r}2300 \\
20 \\
25 \\
5000\end{array}$ & $\begin{array}{r}1 \\
5 \\
18\end{array}$ & $\begin{array}{l}\text { areia seca argibsa } \\
\text { areia saturacta contamirada } \\
\text { embasamento cristalino fraturado + } \\
\text { solo alteracáo contaminado } \\
\text { embasamento cristalino }\end{array}$ \\
\hline 05 & $\begin{array}{r}8500 \\
4500 \\
14000 \\
140\end{array}$ & $\begin{array}{r}1 \\
8 \\
15\end{array}$ & $\begin{array}{l}\text { areia de dunas soca } \\
\text { areia argilosa seca } \\
\text { areia seca } \\
\text { areia saturacta }\end{array}$ \\
\hline 06 & & & resultados não confiáveis \\
\hline 07 & $\begin{array}{r}170 \\
15 \\
130\end{array}$ & $\begin{array}{l}1 \\
9\end{array}$ & $\begin{array}{l}\text { areia argibsa seca } \\
\text { areia saturada muito contaminada } \\
\text { embasamento fraturado }\end{array}$ \\
\hline 08 & $\begin{array}{r}555 \\
30 \\
1500 \\
40 \\
825\end{array}$ & $\begin{array}{l}1 \\
1 \\
7 \\
6\end{array}$ & $\begin{array}{l}\text { areia orgánica seca } \\
\text { argila seca } \\
\text { areia seca } \\
\text { areia saturada } \\
\text { embasamento cristatino fraturado }\end{array}$ \\
\hline 09 & $\begin{array}{r}30 \\
10 \\
350\end{array}$ & $\begin{array}{l}1,5 \\
9,5\end{array}$ & $\begin{array}{l}\text { aterro argiloso } \\
\text { areia saturada organica muito contamirada } \\
\text { embasamento cristalino fraturado }\end{array}$ \\
\hline 10 & $\begin{array}{r}110 \\
10 \\
30 \\
350\end{array}$ & $\begin{array}{l}1 \\
4 \\
9\end{array}$ & $\begin{array}{l}\text { areia organica seca } \\
\text { areia saturada muito contaminada } \\
\text { arela saturada contamirada } \\
\text { embasamento cristalino fraturado }\end{array}$ \\
\hline 11 & $\begin{array}{r}15 \\
50 \\
40 \\
150\end{array}$ & $\begin{array}{l}0,5 \\
3,5 \\
7,0\end{array}$ & $\begin{array}{l}\text { argita arenosa seca } \\
\text { areia argilosa saturada } \\
\text { areia satura da contaminada (ou água salgada) } \\
\text { embasamento cristalino fraturado }\end{array}$ \\
\hline 12 & $\begin{array}{r}20 \\
200 \\
45 \\
50 \\
100\end{array}$ & $\begin{array}{l}0,5 \\
0,5 \\
3,0 \\
8,0\end{array}$ & $\begin{array}{l}\text { argila não seturada } \\
\text { areia saturaca } \\
\text { areia argilosa saturada } \\
\text { solo de alteraçăo argiloso } \\
\text { embasamento cristalino fraturado }\end{array}$ \\
\hline 13 & $\begin{array}{r}300 \\
1500 \\
50 \\
2000\end{array}$ & $\begin{array}{l}0,5 \\
2,5 \\
8,0\end{array}$ & $\begin{array}{l}\text { areia orgánica seca } \\
\text { areia seca } \\
\text { areia saturada pouco contaminada } \\
\text { embasamento cristalino }\end{array}$ \\
\hline 14 & $\begin{array}{r}10 \\
150 \\
20 \\
500\end{array}$ & $\begin{array}{r}0,5 \\
1,0 \\
10,0\end{array}$ & $\begin{array}{l}\text { areia argilosa orgánica saturada com crostas de Fe } \\
\text { areia saturaca argilosa } \\
\text { areia argilosa orgânica saturada contaminada } \\
\text { embasamento cristalino }\end{array}$ \\
\hline
\end{tabular}




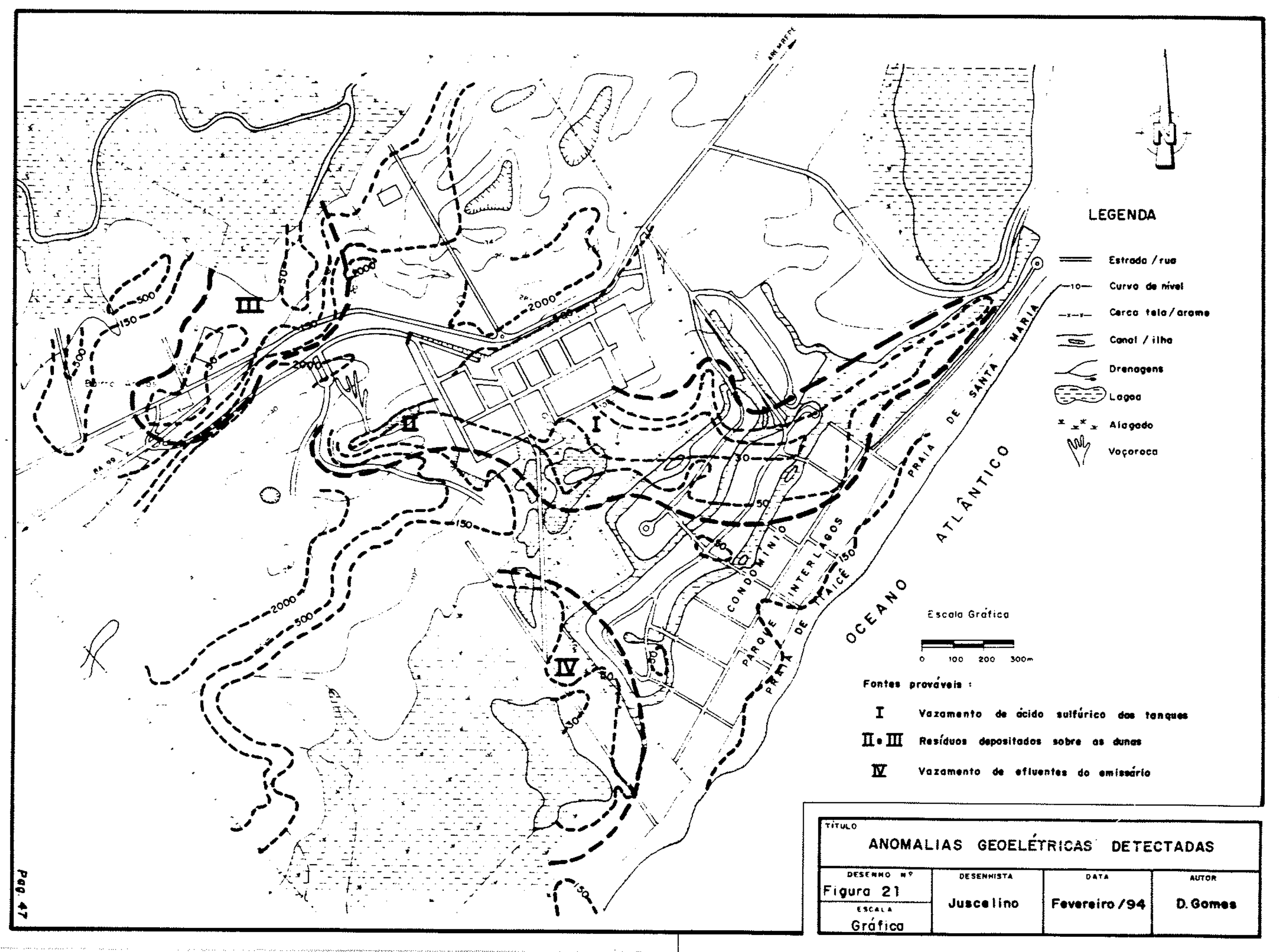




\subsection{IMPACTO ÀS ÁGUAS SUBTERRÅNEAS}

\subsubsection{Resultados Analfticos}

A Tabela 5 mostra os resultados da primeira campanha de análises químicas efetuada. Como pode ser visto, os principais parámetros encontrados foram o sulfato, $\mathrm{pH}$, Ferro solúvel $\left(\mathrm{Fe}^{2+}\right) \mathrm{e}$ condutividade elétrica. Além destes, considerados como os principais indicadores da poluição industrial, outros metais também foram detectados em concentraçōes elevadas, tais como Mn, $A \ell$ e Ti.

A Tabela 6 mostra os valores de $p H$, condutividade elétrica, sulfato e $\mathrm{Fe}^{2+}$ nas águas, para as cinco campanhas. o comportamento dos principais poluentes é discutido no próximo item.

Esta tabela também mostra os resultados das amostras de controle. As réplicas mostram que a precisão do laboratório é aceitável com a maioria dos parâmetros estando dentro da faixa de $20-30$ \%, como por exemplo $V(20 \%), S_{4}(16 \%)$, cloreto $(4,5 \%), \mathrm{Fe}(30$ $\%), M n(25 \%)$ e $A l(23 \%)$. Entretanto, alguns parâmetros apresentaram variações maiores, tais como $\mathrm{Cr}^{6+}(50 \%), \mathrm{Pb}$ (55 \%)

e $\operatorname{Zn}(39 \%)$, normais nas baixas concentrações encontradas. 0 pior valor ocorreu para o Ti (98\% de diferença), provavelmente devido à presença de colóides. 


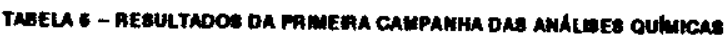

\begin{tabular}{|c|c|c|c|c|c|c|c|c|c|c|c|c|c|c|c|c|c|c|c|c|}
\hline & rime & it & ponoun- & $\begin{array}{l}\text { aconeros } \\
\text { imotech }\end{array}$ & 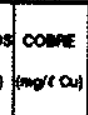 & 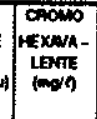 & mino & $\begin{array}{l}\text { ranuowo } \\
\text { imoing }\end{array}$ & monos & \begin{tabular}{|l|} 
Fenio \\
sacica \\
molfat
\end{tabular} & mavanss & molaseon & oremes & 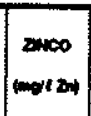 & $\left|\begin{array}{l}\text { musato } \\
\text { mogr sones }\end{array}\right|$ & $\begin{array}{l}\text { werto } \\
\text { imote }\end{array}$ & 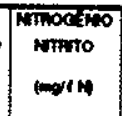 & 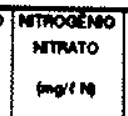 & 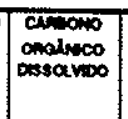 & $\int_{\operatorname{man}}^{\operatorname{man}}$ \\
\hline ins & & $\left.\int x-\infty\right)$ & & 200 & 10 & 0,00 & & 02 & & 0.9 & 0.1 & 0.8 & 0.00 & 1 & $\infty$ & + & & 10 & & ANeGrie \\
\hline 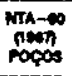 & & $=-30$ & & 200 & & $0.0 \%$ & & & & 0,3 & 0,06 & & 0.00 & $\infty$ & & & & & & \\
\hline $12-8 t$ & 27,4 & 4.8 & 0,4 & 78 & 10 & 0,012 & No & no & $<0,1$ & 200 & 0.04 & 8.7 & No & 0.07 & 10.0 & 20 & no & No & $\omega$ & 1200 \\
\hline$n-\infty$ & $2 \infty$ & 28 & $m .0$ & 12,0 & 0,19 & 0,02 & ס & 0.000 & $<0.1$ & 10,0 & 0,46 & 2.40 & $0.8 \pi$ & 0,4 & 100,0 & 20 & No & No & 140 & 220 \\
\hline$n-\infty$ & 20.4 & 40 & $\$ 0.0$ & 10 & No & 0.08 & מג & No & $<0.8$ & $4.1 \%$ & 0.74 & 7.3 & 0.10 & 0.04 & 4.0 & 12 & no & $0,0 \mathrm{~m}$ & 40 & 14,0 \\
\hline$n-a$ & 202 & 4.0 & $\infty, 4$ & 100 & no & 0,01 & $10 \pi$ & no & $<0,1$ & $1, \omega$ & 0.06 & 2.17 & 10 & $0, \infty$ & 0 & 102 & No & $0, \infty$ & 102 & 120 \\
\hline $22-\infty$ & 200 & $7 x$ & 22000 & soce, & 0.04 & - & 0.60 & to & $<0.9$ & s.e. & 0,14 & 10.6 & 10 & 0.04 & 1000 & $m, 0$ & 0.00 & 0.00 & 180 & $\omega_{0}$ \\
\hline $22-\infty$ & 27. & .0 & 0060 & (11.8 & No & jo,pe & 0.87 & No & $<0,1$ & 10,30 & 0.6 & 10.7 & 10 & $0, \infty$ & 1700.0 & 10,4 & no & 10 & 7.8 & 100 \\
\hline m-or & 200 & $s$ & $=0$ & 107,0 & No & No & $m$ & 10 & $e 0,9$ & $3 \times 20$ & $2 n$ & 1,16 & No & to & 200.0 & No & אo & 0.000 & 14.6 & 20 \\
\hline $22-\infty$ & $2 \infty 2$ & 0 & 1000.0 & $\infty$ & No & No & 80 & No & $<0,1$ & $3 m$ & 0.17 & 128 & no & No & 200 & 10,0 & No & 0,00 & 29,4 & 4.0 \\
\hline$n-\infty$ & n.: & .0 & me: & mo & no & no & No & D & $<0.4$ & so & 0,13 & 1,2 & 10 & - & $n$ & 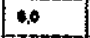 & No & D.ee & 90 & 20 \\
\hline $22-10$ & 27,3 & 20 & 700.0 & $\infty$ & no & No & No & 10 & $<0.1$ & 420 & $0 . x$ & 2.16 & No & 0,00 & 2000 & 7,0 & no & 0.0 & 100 & $\infty$ \\
\hline$n-11$ & $\mathbf{m}, 0$ & 1.0 & 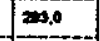 & 300 & No & No & no & No & $<0,1$ & 0,64 & 0,00 & 0.16 & no & no & 20 & 10,4 & $N$ & 0,08 & $\therefore 7$ & 40 \\
\hline $\mathrm{nz}_{-12}$ & 23.4 & is & $30 \%$ & $\infty, 0$ & No & No & no & no & $<0.8$ & 2,12 & 0.12 & 248 & o & 10.00 & 20 & 1000 & No & 0.00 & 0.7 & 20 \\
\hline 22-11 & 23.8 & 60 & 177.0 & 22.6 & $1^{0,00}$ & No & No & No & $<0,1$ & 22 & 0,07 & $3 n$ & No & $0, \infty$ & 100 & 10,4 & No & 0,0 & 17.4 & 1.0 \\
\hline $22-14$ & $\infty$ & $x$ & $\infty$ & 10.0 & 0.40 & 0.04 & ספ & No & $<0,1$ & 126 & 0.45 & 103 & No & a.10 & 10,0 & 10 & No & 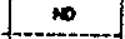 & $\therefore$ & 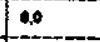 \\
\hline$n-16$ & $2 \pi, 4$ & 4 & 200 & 200 & 0,00 & 0.0 & No & 0,000 & $<0.1$ & 24,0 & 20 & $\omega$ & $0, \infty$ & 2,0 & 10000 & 10 & No & $\infty$ & $\omega$ & No \\
\hline R2-10 & 212 & 20 & 10000 & 2n: & 0,00 & 10.02 & $a s$ & $0.4 \pi$ & $<0.9$ & 100 & 0.81 & $\infty 2$ & 10.22 & {$[0, m$} & 100000 & No & No & no & 38.4 & 16 \\
\hline $22-17$ & $2 \infty 4$ & 1,0 & tenos.0. & 20,0 & no & 10,02 & 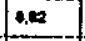 & $10 \mathrm{~m}$ & $<0,1$ & $\infty 00.0$ & 20 & $m: 0$ & 0.0 & $i m$ & 10200000 & $\infty$ & No & $0 . \infty$ & $2 \times 20$ & $\infty$ \\
\hline $2-10$ & {$[2,1$} & 4 & 206,0 & 16,0 & 0,00 & No & No & No & $<0,3$ & 601 & 0,17 & 20 & to & $0.2 x$ & $m o$ & 22 & No & $\infty, \infty$ & 2,4 & 200 \\
\hline (2-10 & 202 & 30 & ]1400,0 & 14 & 10 & 3.01 & No & 0.017 & $<0.1$ & 1820 & 200 & 02 & 0,16 & 10n & 10000,0 & No & 0,000 & 0,04 & .2 & 20 \\
\hline$n-20$ & 20.4 & 20. & 200,0 & 0 & $0.2 x$ & $\$$ & 10 & N & $<0,1$ & $\infty 0$ & 0.06 & $2 x$ & 10 & 0.10 & 400 & 40 & so & 0.00 & .7 & 20.0 \\
\hline R-2t & 0,8 & 20 & 212000 & 200 & No & $\therefore$ & 1,006 & 0.001 & $<0.9$ & 0,4 & $2 \pi$ & $\infty, 0$ & No & 0.07 & 10000 & 20 & No & 10 & 0.7 & 40 \\
\hline n-22 & 20 & $9 x$ & 230.0 & 10.8 & 0.00 & No & $\because m$ & so & $<0,1$ & $1, \infty$ & 0,18 & 20 & No & 0,04 & 280 & 40 & 10 & $\therefore<$ & 200 & 18,0 \\
\hline $12-21$ & $2 n .1$ & 30. & Droo & 180 & $\infty$ & 0.000 & 12,3 & No & $<0,1$ & 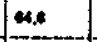 & 7,0 & sees & No & 0.0 & 10090 & 8.0 & No & No & 10.0 & 200 \\
\hline $2-24$ & 20,7 & 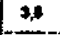 & 12000 & 200.0 & 0.78 & No & 11 & 0.002 & $<0.8$ & 113,0 & 1100 & 21200 & 10 & 10, & 11000 & 00 & 10 & D & 20 & 1000 \\
\hline $22-25$ & 207 & 25 & 1340,0 & $m, 0$ & on & $\therefore$ & No & 0.372 & $<0.1$ & 200,0 & is & 780 & 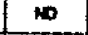 & 2006 & 100000 & 12 & No & - & 100 & 200 \\
\hline $3-\infty$ & $m$ & 20 & $=0000$ & 40 & $N$ & $0 . \infty$ & 10 & 0,001 & $<0.9$ & 424,0 & 100 & $n$ & 10 & $2 \pi$ & 2000 & to & no & No & as & $\infty 0,0$ \\
\hline 8p-o4 & 27,4 & $\infty$ & 1003.8 & 10,8 & $\infty$ & 0.02 & No & to & $<0.1$ & 1.07 & 0.10 & 400 & No & 2,84 & 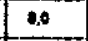 & 10,0 & no & $<0,0 x$ & 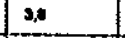 & 20 \\
\hline$x-\infty$ & 20,7 & 40 & 1280.0 & 128 & $0, \infty$ & 10,000 & No & 10 & $<0,1$ & No & $0 ., 11$ & {$[x$} & 10 & $0,0,0$ & 20 & $\$ 0$ & no & 0,10 & 4 & 20,0 \\
\hline$(\mathrm{A}-2 \mathbf{2}$ & 20 & 20 & 10040 & n: & 10.0 & 10 & No & No & $\begin{array}{l}<0,1 \\
\end{array}$ & $\infty$ & $1, \infty$ & $m$ & $\infty$ & 100 & $\infty$ & 24 & No & 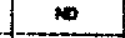 & $<20$ & 40 \\
\hline un-so & $\infty, 16$ & 18 & resono & 218 & No & 0.04 & 10 & $0=21$ & $<0,1$ & 74 & 0,01 & $\mid$ & No & $0, \infty$ & nose & 20 & No & $0, \infty$ & $\infty$ & 20.0 \\
\hline u-r & $2 n 0$ & 48 & mas, & $\infty$ & No & 10 & No & No & $<0,9$ & No & {$\left[\begin{array}{ll}0.0 \\
0\end{array}\right.$} & 1,00 & 10 & 0,00 & 100 & $\$ 0$ & No & 0 & 43 & $\therefore$ \\
\hline $4 a-2$ & $\mid 27,4$ & 4 & mo & $\infty 0,0$ & No & No & No & No & $<0,8$ & No & 0,0 & $1, \infty$ & 10 & 0,00 & 1000 & 20,0 & No & 0,0 & 4 & 20 \\
\hline$u-30$ & $m 0$ & a. & 2000 & 200 & 10 & No & No & 0.000 & $<0,1$ & 3,46 & 0,10 & 1,00 & to & 0.00 & 240 & 10,6 & $N$ & $\therefore$ & 87 & 10 \\
\hline $\mathbf{L A - \mu}$ & 20.1 & 80 & 700.0 & $\infty$ & 10 & 10 & No & 0.007 & $<0,8$ & - & $0, \infty$ & 203 & No & 0,00 & 270,0 & No & No & 0 & 121 & 100 \\
\hline$u-x$ & 20,4 & 40 & $\infty, 0$ & 11,0 & No & to & 10 & No & $<0,1$ & 0.0 & $\infty, \infty$ & $2 \omega$ & No & Len & $\infty \infty, 0$ & 0.0 & No & $\infty$ & 20 & 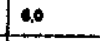 \\
\hline$u-*$ & $\infty .1$ & 4.6 & m.8. & 17,0 & No & No & No & No & $<0,1$ & $0 . n$ & 0,14 & 10 & 10 & 10 & to & 0 & to & No & 43 & No \\
\hline$u-n z$ & $\mathbf{m e}$ & 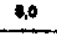 & 200 & $\omega$ & 10 & No & $N$ & No & $<<.9$ & 0.60 & 0.00 & 10 & No & to & $\mu_{0}$ & 10,0 & 10 & 10 & 180 & 20 \\
\hline$\underline{u}-\boldsymbol{u}$ & 20 & 20 & 1000 & ss & $\infty$ & No & 0,01 & No & $<0,9$ & 200 & 0.23 & $2 x$ & No & 0,000 & 100 & 20 & No & 10 & 13 & $\infty 0,0$ \\
\hline$\stackrel{n-\infty}{n-\infty}$ & $m$ & 4 & (2., & .6. & No & No & סNה & No & $<0,1$ & 0.01 & No & 216 & No & $\infty$ & 20 & 80,4 & No & 10 & 2,4 & 10 \\
\hline $\begin{array}{l}n-\infty \\
p \rightarrow \infty\end{array}$ & $m$ & 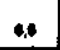 & 132 & 20 & ס & no & No & ס & $<0,1$ & ס & $\mid 0, \infty$ & $\infty$ & to & No & 10.0 & 12 & 10 & No & 24 & ne.0 \\
\hline
\end{tabular}


TABEA 6: VAAIAÇAO DE PH, CONDUTIVIDADE ELEGTICA E SULFATO NAS AMOSTRAS DE AGUAS

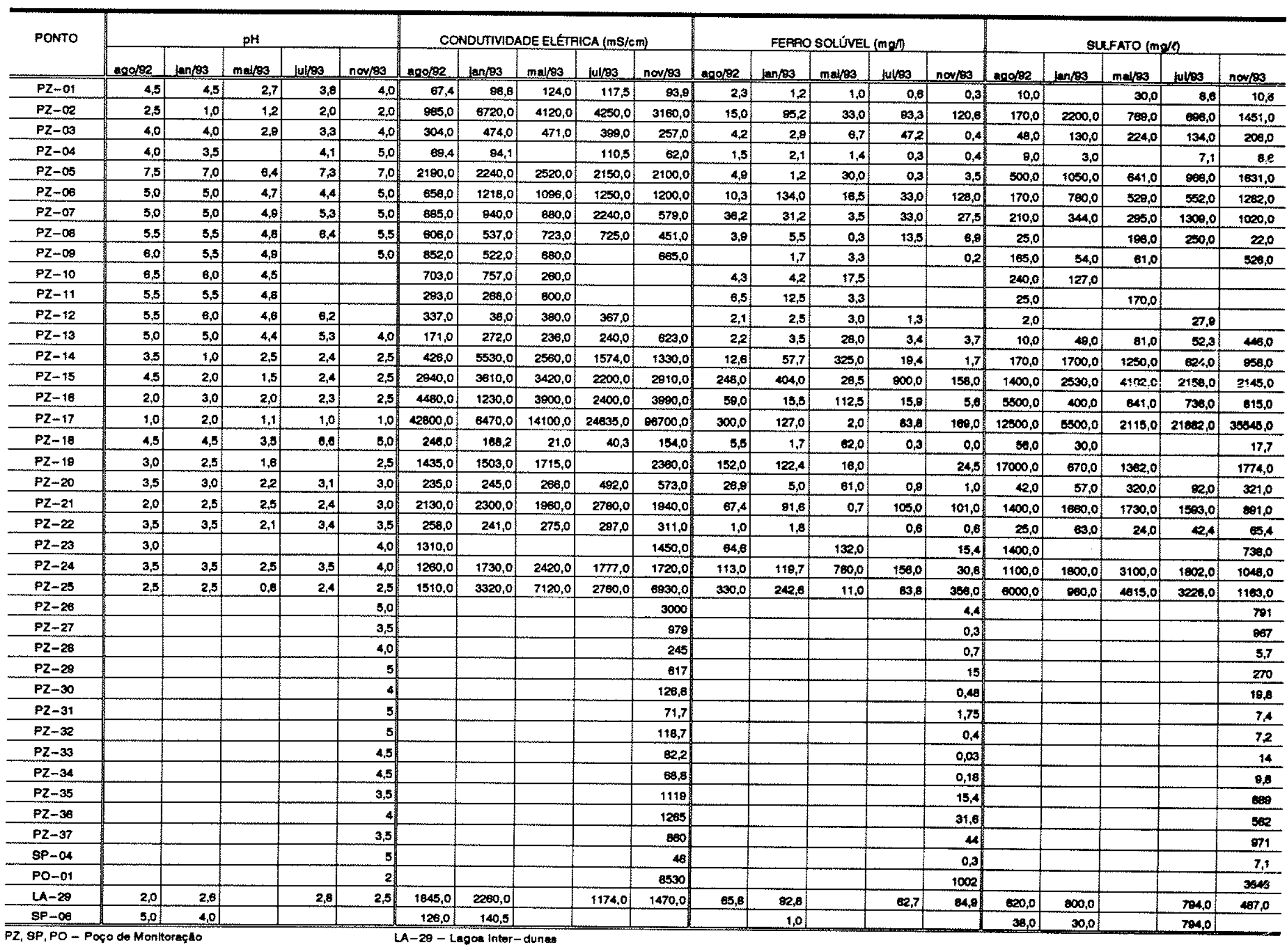


3.4.2. Distribuição Espacial dos Principais Parâmetros

- Sulfato

Este Ion pode estar presente nas águas subterrâneas principalmente na forma de $\mathrm{SO}_{4}{ }^{2-}$ ou $\mathrm{HSO}_{4}^{-}$, sendo que o ultimo predomina em águas muito ácidas ( $\mathrm{pH}<2$, aproximadamente), devido à dissociação incompleta do acido sulfúrico (HEM, 1985). Ions com metais também foram relatados, tais como $\mathrm{FeSO}_{4}(\mathrm{aq}), \mathrm{MnSO}_{4}(\mathrm{aq}), \mathrm{AlSO}_{4}{ }^{+}(\mathrm{aq})$ em águas ácidas de minas e $\mathrm{NaSO}_{4}^{-}(\mathrm{aq})$ e $\mathrm{CaSO}_{4}(\mathrm{aq})$ em aguas não poluídas.

Segundo PARRY \& BELL (in CAIRNEY, 1987) águas com sulfato em concentrações excessivas (acima de $400 \mathrm{mg} / \ell$ ) não são aceitáveis para consumo humano, principalmente na presença de ions magnésio e sódio, devido à possibilidade de irritação gastrointestinal. Também ressaltam os problemas de fito-toxicidade, quando a concentração de sulfatos no solo excede os 200-400 mg/g, em solos ácidos; e ataque a instalações de concreto e ferro-fundido, com consequente diminuif̧ão de durabilidade. o sulfato ferroso é particularmente perigoso se ingerido na forma pura. Por exemplo, a ingestão de 7,8 $\mathrm{g}$ deste composto pode ser fatal a crianças pequenas.

Águas com concentraçōes acima de $500 \mathrm{mg} / \ell$ de sulfato podem ainda produzir efeitos laxativos (BATALHA \& PARLATORE, 1977).

A distribuição de sulfato em agosto de 1992, é relacionada aos depósitos de residuos nas dunas, a um vazamento na área de tancagem de ácido sulfúrico, perdas no pátio de enxofre e provavelmente lagoa de efluentes/acidentes no emissário submarino, conforme mostra a Figura 22. 
As aguas contaminadas atingiram áreas de aproximadamente $750.000 \mathrm{~m}^{2}$ acima do limite de potabilidade do Decreto 12.486 (NTA-60, Estado de São Paulo, $250 \mathrm{mg} / \mathrm{l}$ ), com um volume total em torno de $225.000 \mathrm{~m}^{3}$ admitindo-se espessura saturada média de $10 \mathrm{~m}$ e porosidade efetiva média de $3 \%$, advindo dos ensaios de bombeamento.

o valor relativamente baixo do $\mathrm{PZ}-02(170 \mathrm{mg} / \mathrm{\ell})$ é indicativo de que a migração da pluma de poluição devido aos residuos dispostos se dá em sentido ao Bairro Areias (SE-NW), predominantemente.

- mapa de isoconcentrações de janeiro de 1993 (Figura 23) mostra um padrão semelhante ao de agosto de 92 , porém há um alastramento da pluma de poluição em sentido ao mar (vide PZ-05, 06 e 07) e rio Capivara Grande (PZ-25 e 24). Entre estas duas campanhas, foram adotadas algumas medidas de eliminação de fontes de contaminação na área industrial, principalmente no pátio de enxofre, onde o muro de contenção foi fechado (junto ao $P Z-19$ ) e os residuos removidos.

Esta medida mostrou ser bastante eficiente, haja visto o decréscimo de concentração no PZ-19, de $17.000 \mathrm{mg} / \mathrm{\ell}$ em agosto de 92 para $670 \mathrm{mg} / \mathrm{l}$ em janeiro de 1993. Durante este mês, foi feito um teste de bombeamento na lagoa entre as dunas, com vazōes de até $100 \mathrm{~m}^{3} / \mathrm{h}$, o que pode ter também contribuido para esta queda, assim como para a elevação dos valores do PZ-02 (de 170 para $2.200 \mathrm{mg} / \mathrm{l})$, pelo deslocamento da pluma.

o volume de águas contaminadas em janeiro de 1993 foi de aproximadamente $350.000 \mathrm{~m}^{3}$. 
A situação em maio de 1993 (Figura 24) mostra uma retração da pluma junto à área próxima ao mar e junto à área industrial, conforme mostra a curva de $1.000 \mathrm{mg} / \mathrm{l}$. 0 poço $\mathrm{pZ} Z 17$, situado imediatamente a jusante dos tanques de acido sulfúrico, mostrou uma queda continua de concentração nestas três primeiras amostragens: de $12.500 \mathrm{mg} / \mathrm{l}$ em agosto $/ 92$ para $5.500 \mathrm{mg} / \ell \mathrm{em}$ janeiro de 1993 e $2.115 \mathrm{mg} / \mathrm{l}$ em maio/93, mostrando que o vazamento de $5 \mathrm{t}$ de $\mathrm{H}_{2} \mathrm{SO}_{4}$ concentrado, ocorrido em 1990 (equivalentes a $4,8 t$ de $\mathrm{SO}_{4}{ }^{2-}$ ), foi um evento puntual assimilado pelo aquifero.

No entanto, este poço (PZ-17) voltou a sofrer uma elevação substancial de concentração em julho/93, ultrapassando os $20.000 \mathrm{mg} / \ell$, em consequência de novos vazamentos nas tubulações de ácido sulfúrico (Figura 25).

Observa-se, nesta amostragem, uma retração nas curvas de 3.000 e o desaparecimento da curva de $4.000 \mathrm{mg} / \mathrm{\ell}$ na área dos residuos, provavelmente ocorrido devido a efeitos de diluição durante a época mais chuvosa.

Finalmente, em novembro de 1993, após a conclusão das obras de impermeabilização dos residuos, descritas no capitulo 4 ocorreu uma diminuição expressiva das curvas de $1.000 \mathrm{mg} / \ell$ na área dos residuos (Figura 26), sendo provavelmente indicativa dos efeitos obtidos com a impermeabilização dos residuos/bombeamento da lagoa inter-dunas.

Por outro lado, a poluição industrial continua aumentando na região dos tanques de ácidos, cujas linhas de distribuição deveriam ser rigorosamente inspecionadas e reparadas, haja visto os valores crescentes do $P Z-17$. O volume de aguas poluidas alcançou $405.000 \mathrm{~m}^{3}$, nesta data, devido ao aumento da contaminação industrial. 
A lagoa de efluentes aparenta também contribuir para o processo poluidor de forma relevante.

o comportamento hidroquimico dos ions sulfato é complexo, envolvendo ação catalisadora de microorganismos tanto na oxidação como na redução do enxofre. Dentre vários grupos, LOPES (in MONIZ, 1975) destaca a importância do gênero Thiobacillus, composto por nove espécies, algumas delas muito resistentes a condiçōes ácidas, como por exemplo Thiobacillus Thioxidans, ativo em águas com pH inferior a 3 em meio aeróbio. Já o Thiobacillus ferroxidans, além de catalisador da oxidaçāo do $\mathrm{Fe}^{3+}$ a $\mathrm{Fe}^{2+}$, também podem promover a oxidação de sulfetos a sulfatos.

Já a redução dos sulfatos a sulfetos parece estar ligada a um grupo limitado de microorganismos anaeróbicos e sensiveis a acidez elevada, não se desenvolvendo em áreas com pH inferior a 5,5, segundo o mesmo autor.

Nestas condições, predomina a espécie Desulfovibrio desulfuricans, capaz de reduzir os sulfatos através de reação autotrófica (sem uso de compostos orgânicos como fonte de energia) esquematizada abaixo:

$$
\mathrm{SO}_{4}^{2-}+4 \mathrm{H}_{2} \rightarrow \mathrm{S}^{2-}+4 \mathrm{H}_{2} \mathrm{O}
$$

Reações heterotróficas (com uso de compostos orgânicos) também podem ocorrer, como, por exemplo:

$2 \mathrm{CH}_{3} \mathrm{CHOHCOOH}+\mathrm{SO}_{4}^{2-} \rightarrow \mathrm{H}_{2} \mathrm{~S}+2 \mathrm{CH}_{3} \mathrm{COOH}+2 \mathrm{CO}_{2}+2 \mathrm{OH}^{-}$

(ácido lático)

(ácido acético) 
Como na área de estudo predominam faixas de pH inferiores a 4, é provável que a redução dos sulfatos não ocorra na maior parte afetada. Entretanto, a presença de sulfeto nas áreas baixas alagadiças ricas em matéria orgânica, principalmente junto ao Condominio Interlagos, onde o $\mathrm{pH}$ é maior, pode ser indicativa da ocorrência destas reações de redução. são necessários mais dados para aclarar esta possibilidade, ja que os sulfetos (como $\mathrm{H}_{2} \mathrm{~S}(\mathrm{aq})$ ) são também estáveis em ambientes pouco oxidantes (HEM, 1985), provenientes de decomposição da matéria orgânica. 


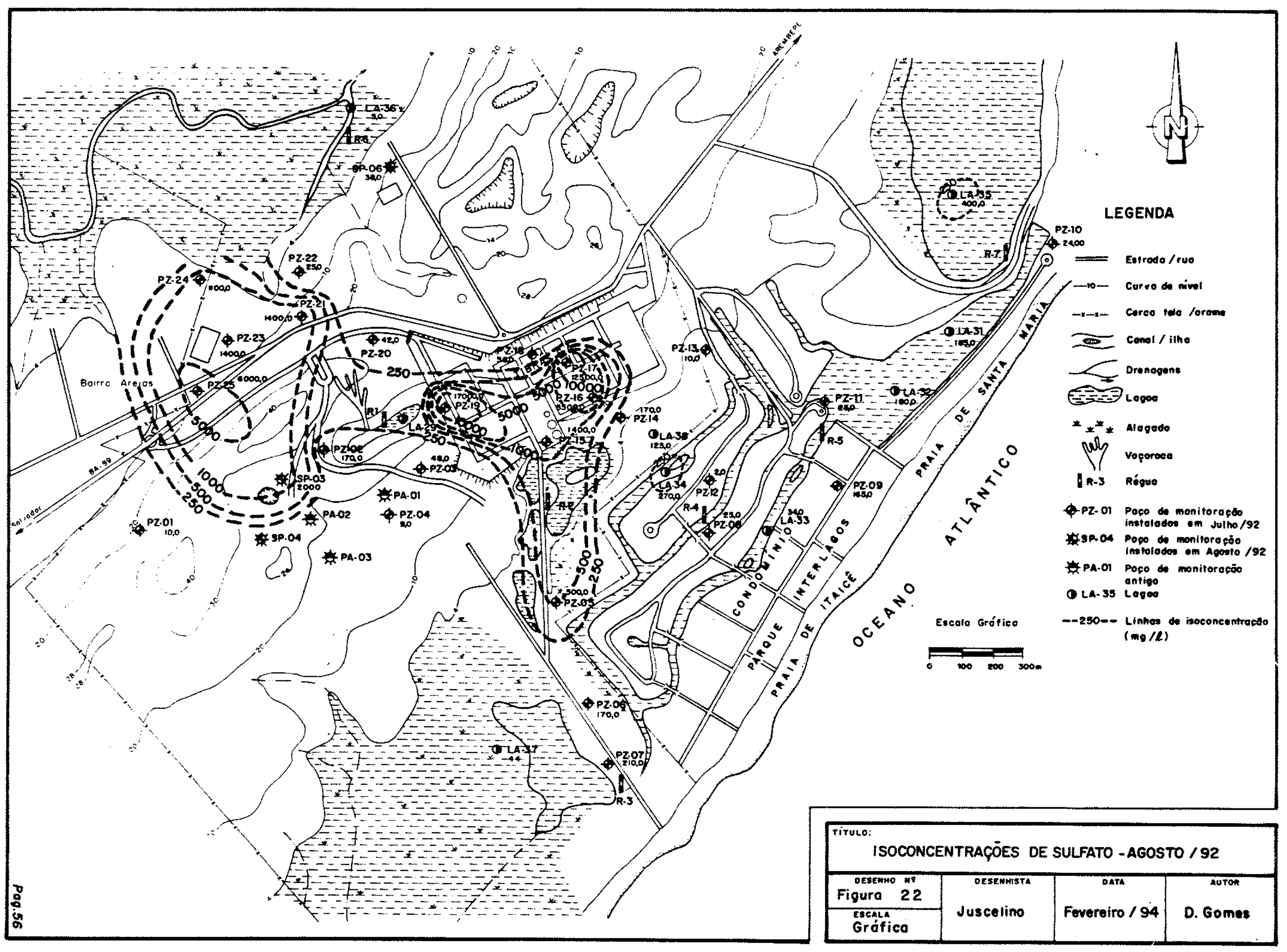




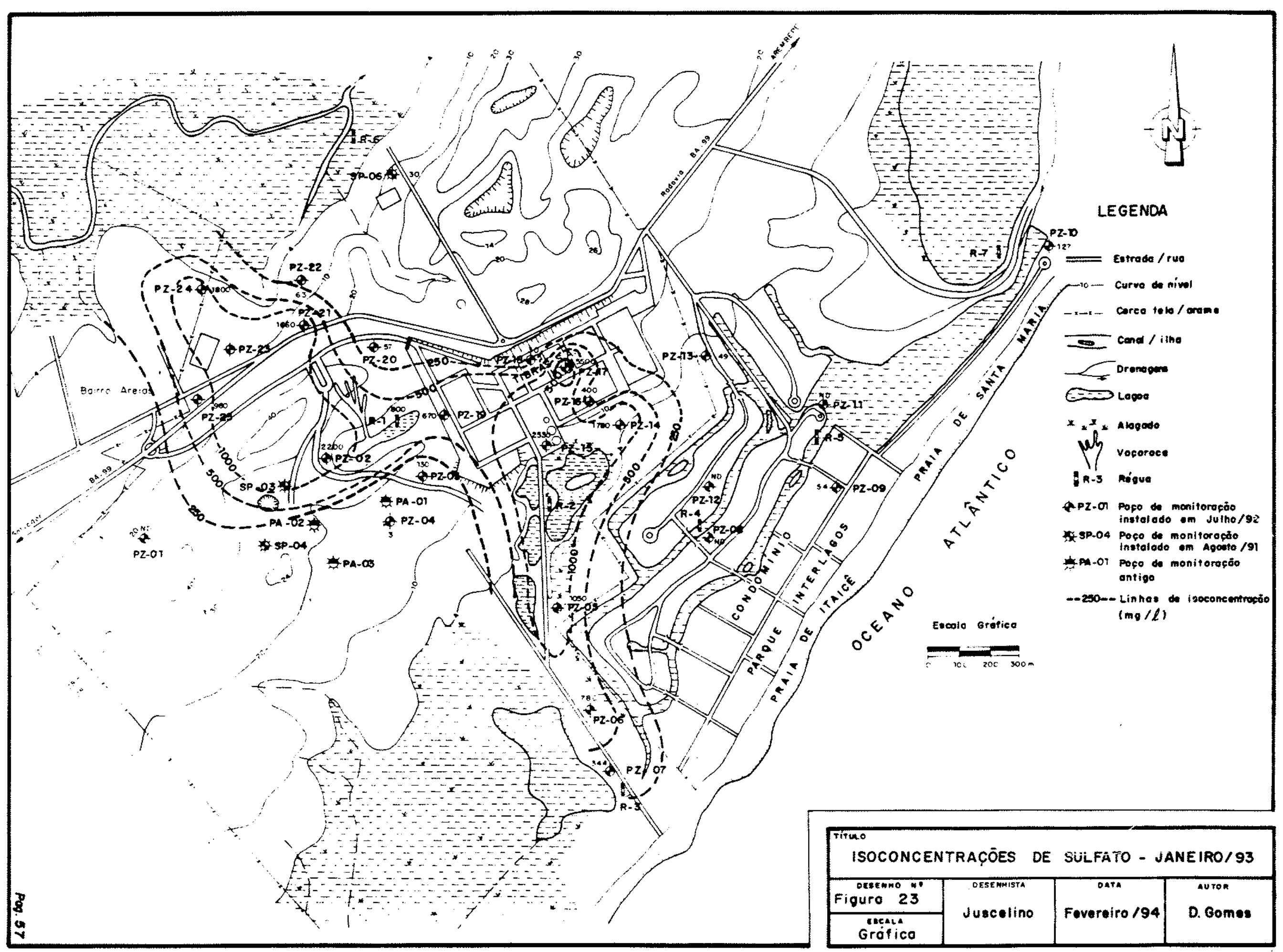




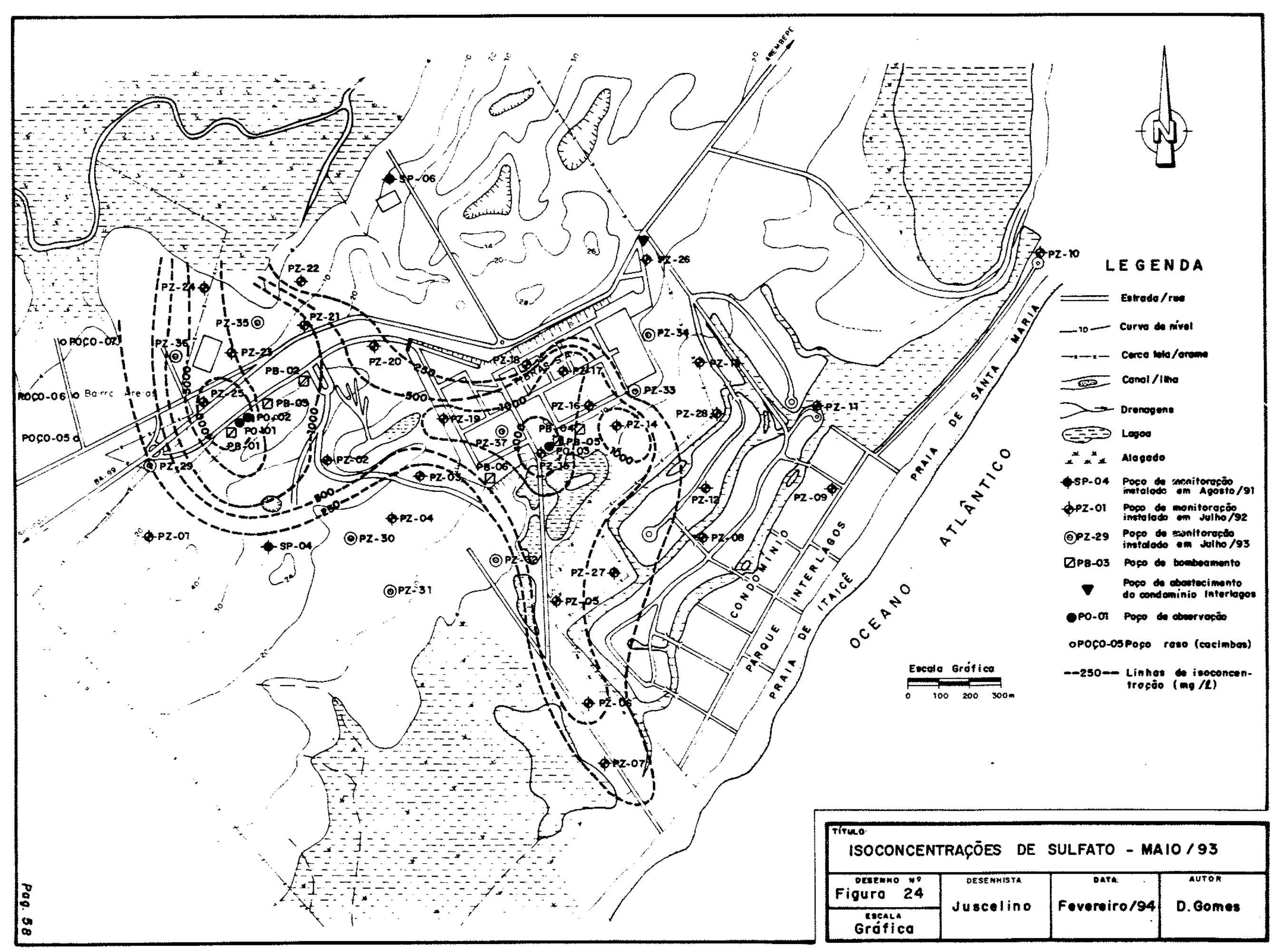




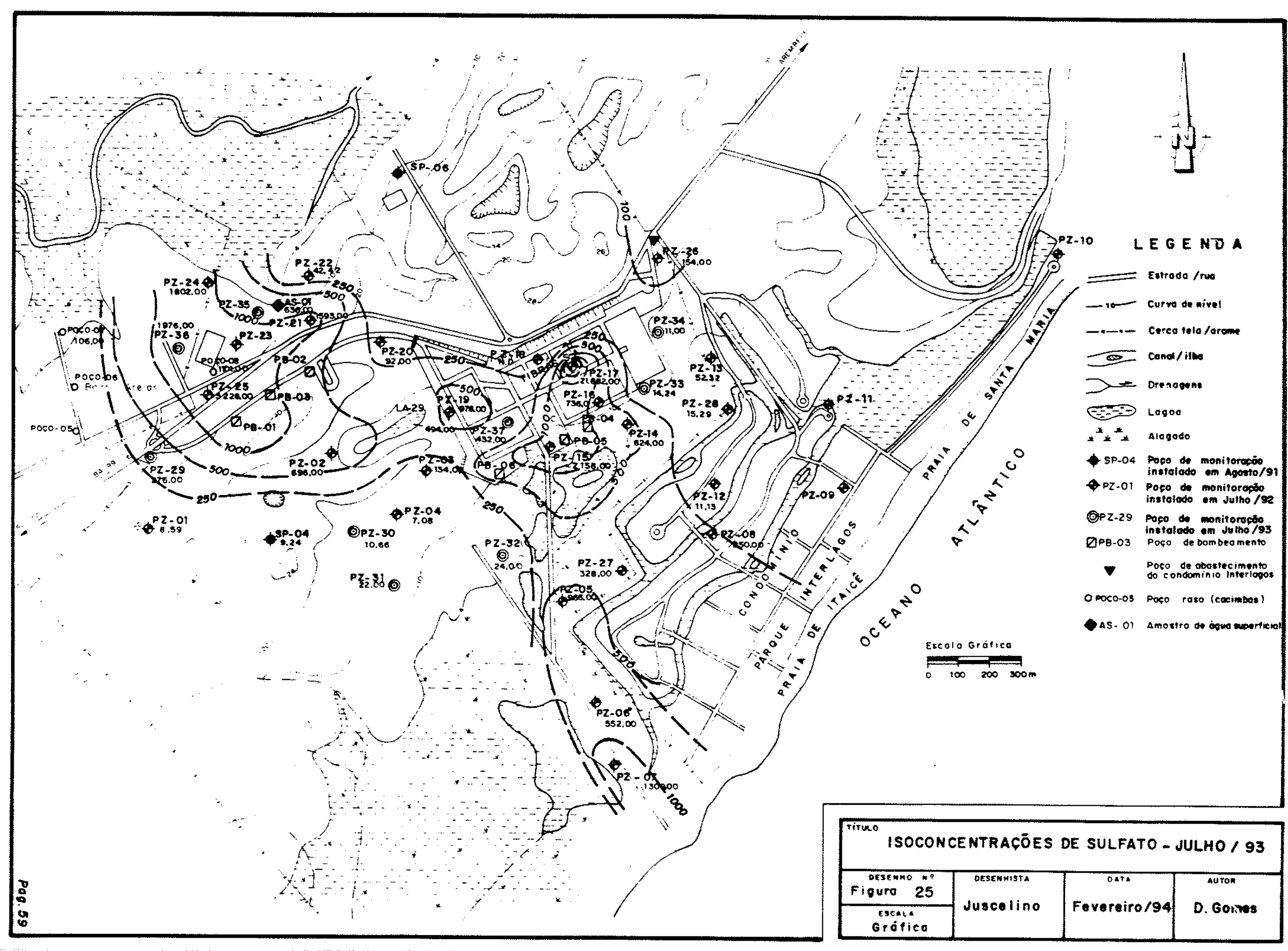




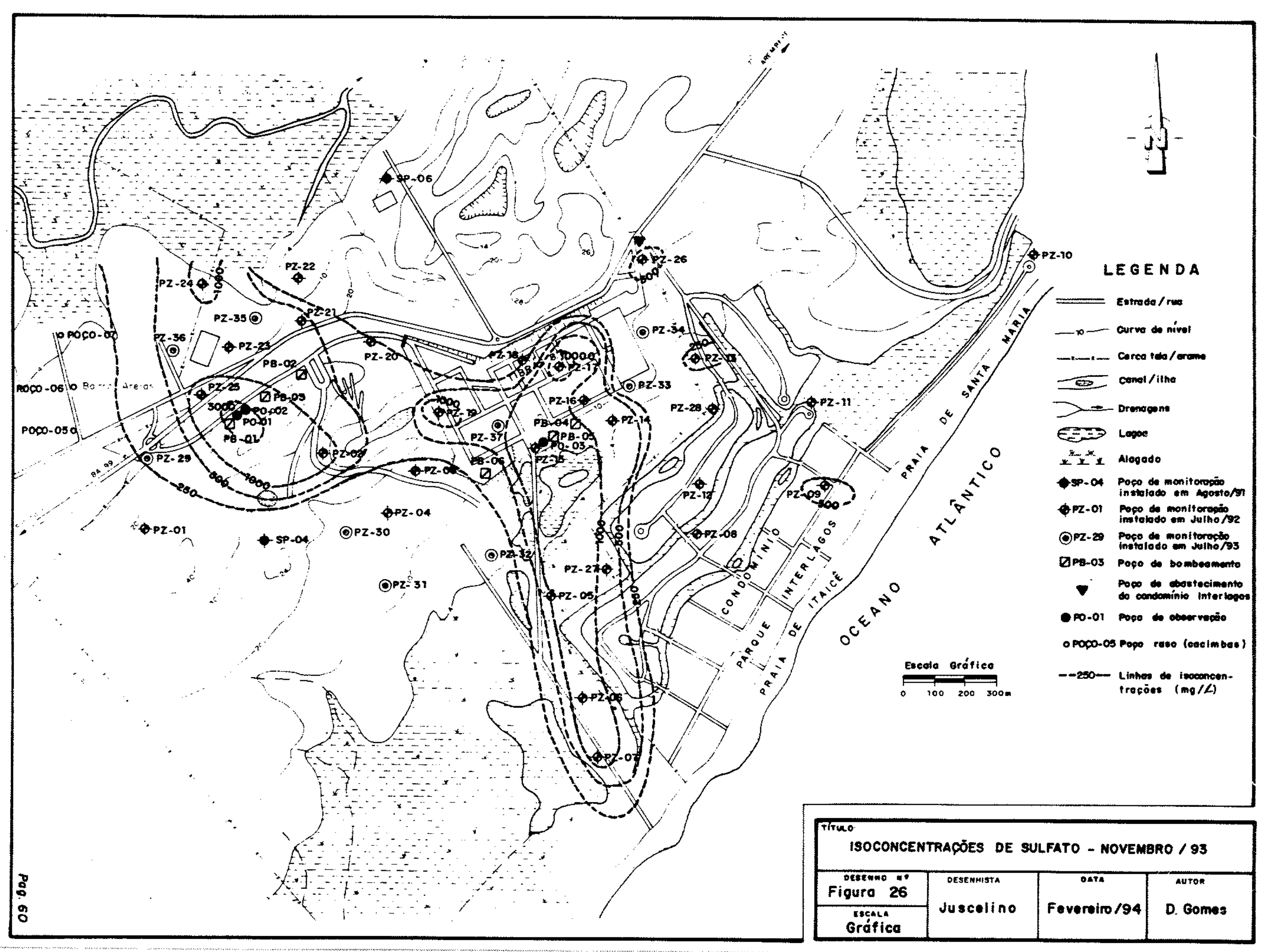


O pH das águas subterrâneas nas 5 campanhas variou entre 0,8 e 7,5. A Figura 23 mostra a situação em agosto de 1992.

Os valores mais baixos estão associados a perdas nos tanques e tubulaçôes de ácido sulfúrico da área industrial. Entretanto, valores muito baixos também são encontrados junto aos residuos.

o solo local é em geral naturalmente ácido, devido à intensa Iixiviação típica de áreas tropicais, ou devido à presença de solos orgânicos nas áreas baixas inunaáveis. $O$ pH das águas em poços não contaminados varia entre 3,5 e 6 .

Os valores mais altos encontrados $(7$ a 7,5$)$ situam-se junto ao PZ-05, sob influência de uma lagoa de efluentes neutralizada periodicamente com soda caústica.

As lagoas e canais do Condominio Interlagos mostraram-se impactadas principalmente nas areas mais próximas à indústria (junto aos poços $\mathrm{PZ}-14$ e 12, com $\mathrm{pH} 3$ ).

As Figuras 28, 29, 30 e 31 mostram a distribuição de $p H$ ao longo das demais campanhas.

Observa-se que a maior pluma de poluição ocorreu em maio de 93 (Figura 28, vide curva de $\mathrm{pH}=3$ ), correspondendo ao inicio da época das chuvas, principalmente na área dos residuos junto ao Bairro Areias.

A situação melhorou em julho, já em plena estação chuvosa e com - bombeamento das águas da lagoa inter-dunas, conforme pode ser visto nas curva de $\mathrm{pH} 2$, tanto na área de residuos, como na área industrial (Figura 29). 
Já em novembro de 1993, a redução é ainda mais clara junto aos residuos e Bairro Areias, com vários poços de monitoração ja chegando a pH 4 (Figura 30). Isto se deve provavelmente às medidas de recuperação ambiental adotadas (impermeabilização dos residuos e bombeamento das águas da lagoa inter-dunas), aliadas ao elevado efeito-tampão dos solos orgânicos das baixadas alagadiças (WUTKE, in MONIZ, 1975).

Ao longo de todas as amostragens, a pluma de poluição devido às perdas de ácidos e outras fontes na área industrial mostrou-se praticamente estável. Este fato mostra que a neutralização das lagoas de efluentes com soda tem auxiliado na contenção das águas subterrâneas ácidas a sul-sudeste.

- principal efeito negativo da acidificação das águas subterrâneas e superficiais locais, além dos danos à fauna aquática, é indireto, através da mobilização de metais pesados tais como aluminio e manganês, que são fito-tóxicos à maioria das plantas (WUTKE, in MONIZ, 1975).

O aumento de pH no Bairro Areais, de 0,8 a 2,5 em julho de 93 ( $p H$ médio 2,7) para 2,5 a 5 em novembro de 93 ( $p H$ médio 3,2) representa uma recuperação expressiva, equivalente a uma queda de $68,5 \%$ na concentraçāo de ions $H^{+}$neste periodo (de $2 \mu \mathrm{g} / \ell$ em julho para $0,63 \mu \mathrm{g} / \ell$ em novembro de 1993). 


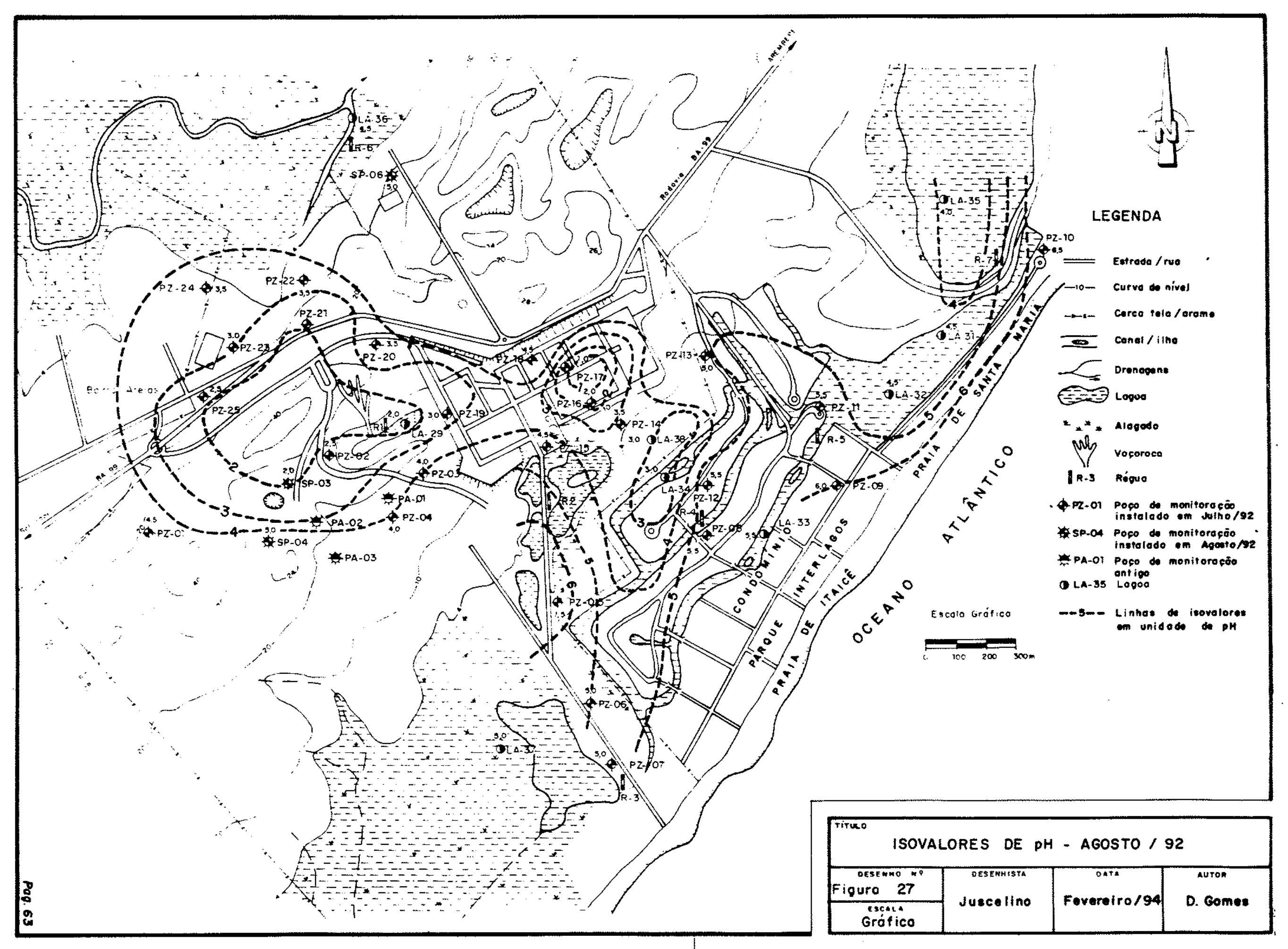




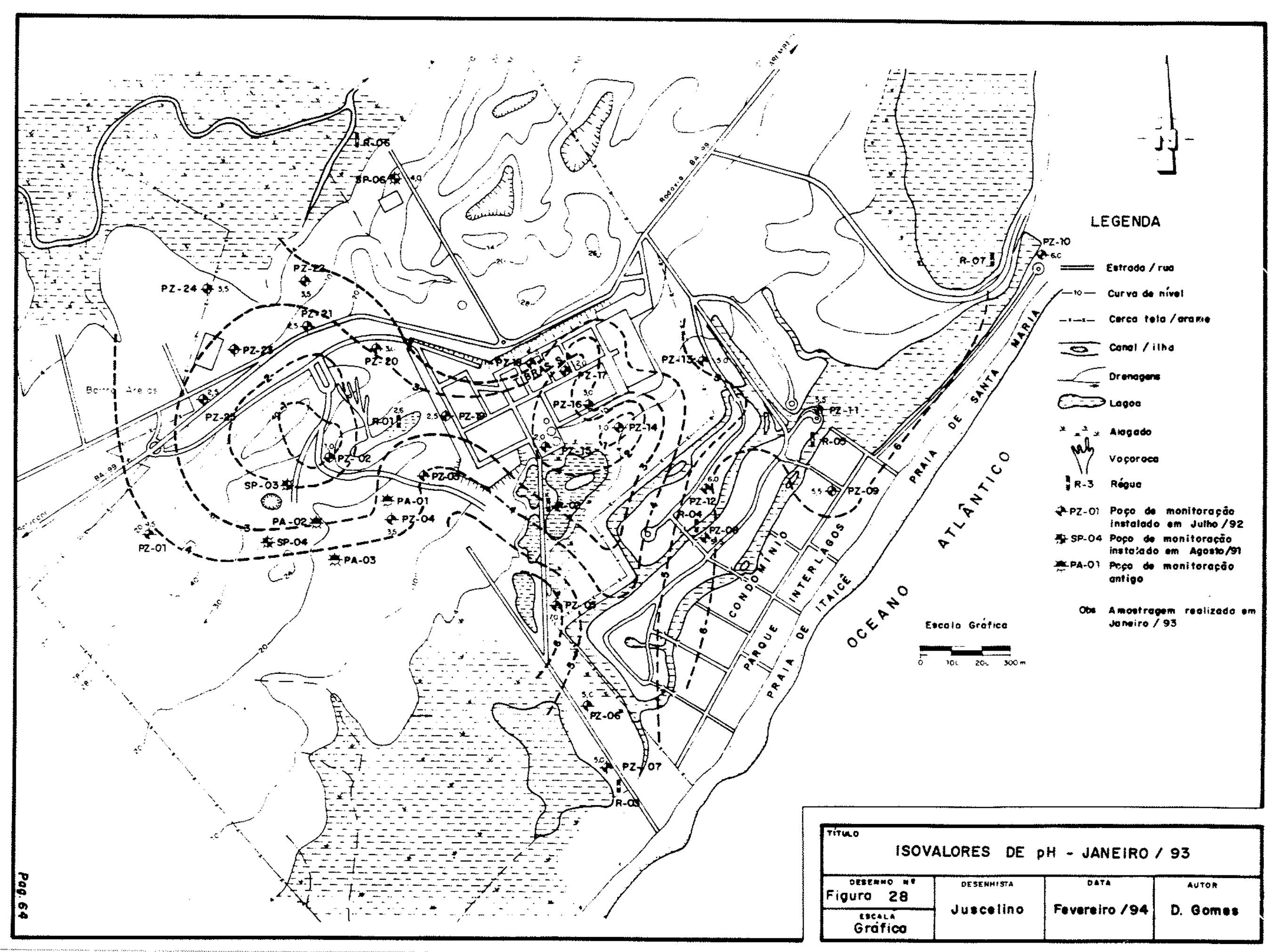




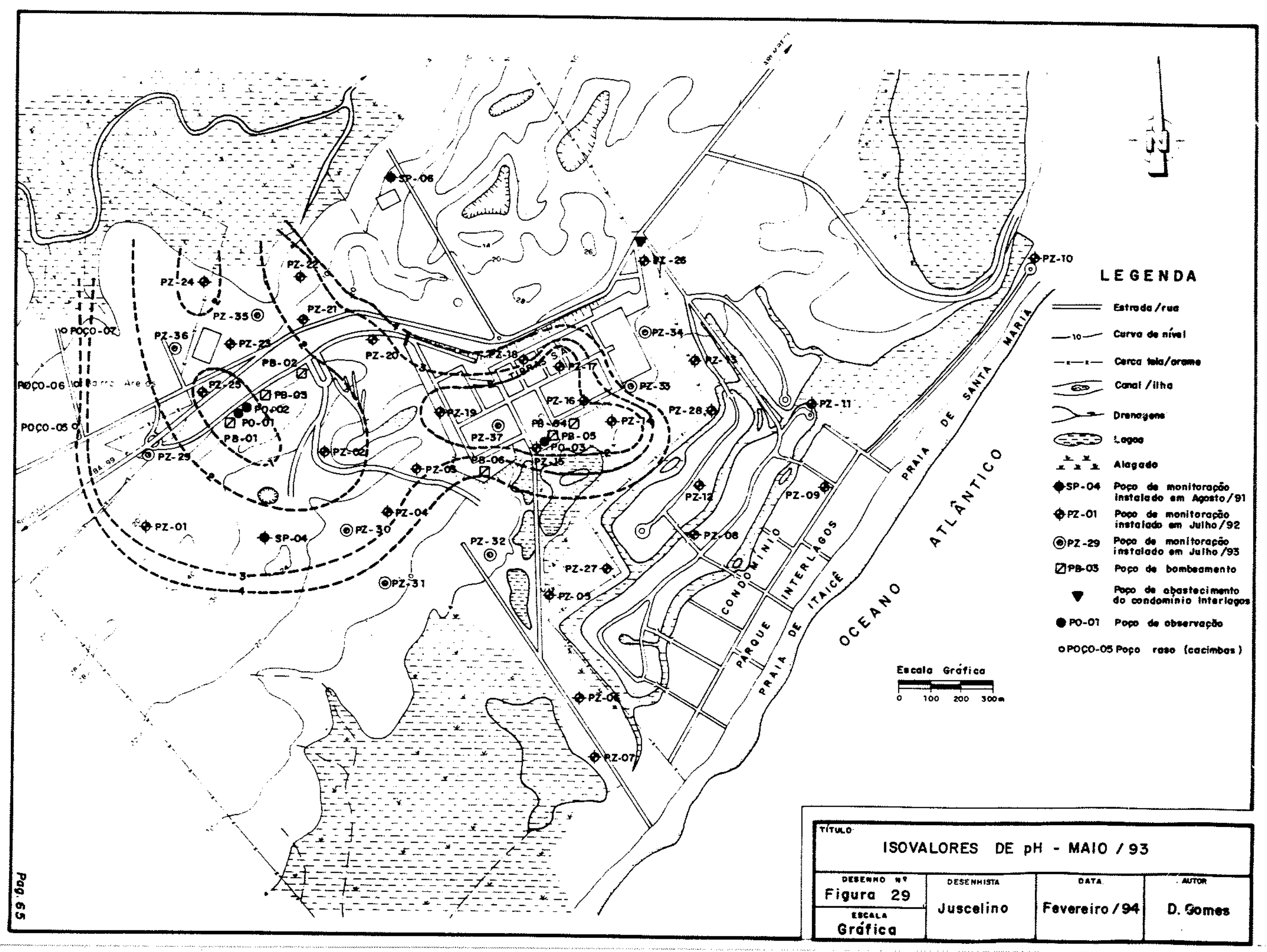




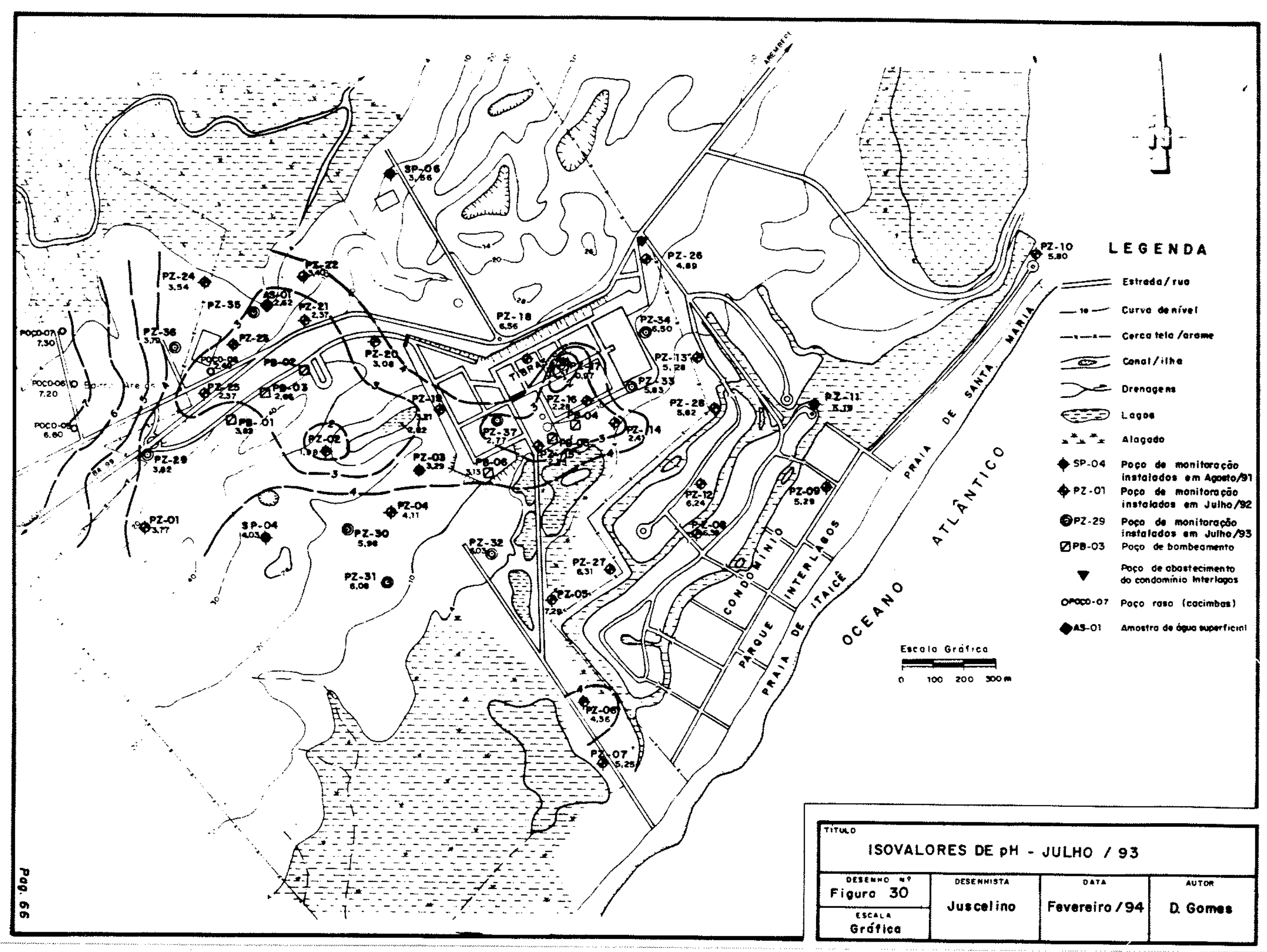




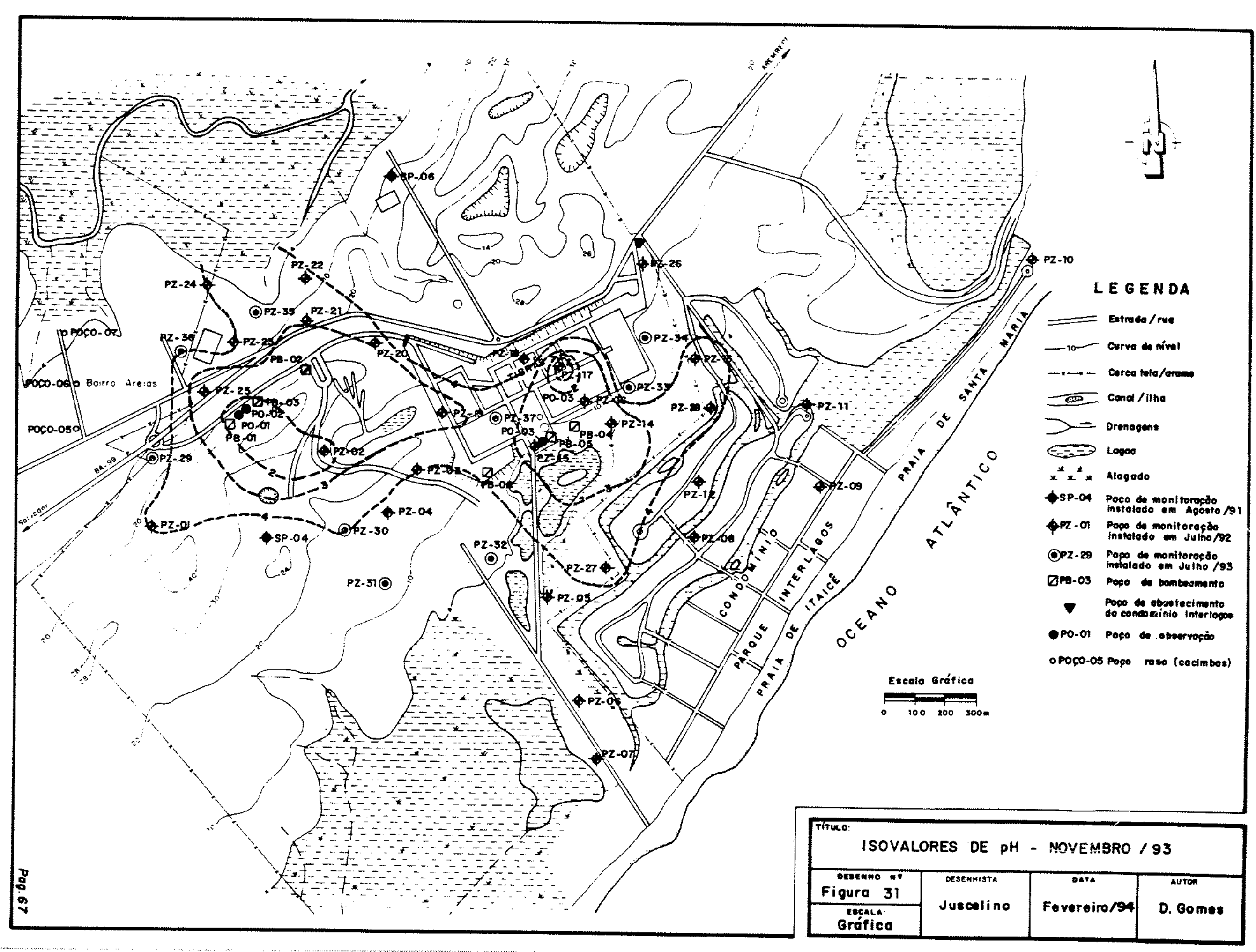


- Ferro Solúvel

o $\mathrm{Fe}^{2+}$ apresentou valores entre 0,03 e $1002 \mathrm{mg} / \mathrm{l}$, com média de $66,2 \mathrm{mg} / \ell$ (desvio padrão $=148,2 \mathrm{mg} / \ell$ ), nas cinco campanhas.

Mesmo os poços de monitoração considerados não contaminados apresentaram valores acima dos limites de potabilidade $(<0,12$ a $4,4 \mathrm{mg} / \mathrm{\ell}$, com média de $1,4 \mathrm{mg} / \ell)$.

A Figura 32 mostra a distribuição deste ion em agosto de 1992, cujas origens podem ser atribuidas às mesmas fontes que os sulfatos.

o volume total de águas subterrâneas contaminadas chegou a aproximadamente $300.000 \mathrm{~m}^{3}$ em agosto de 1992, com uma área de cerca de $1.000 .000 \mathrm{~m}^{2}$.

Este Ion, que também pode estar presente na forma de $\mathrm{FeSO}_{4}(\mathrm{aq})$, segundo HEM (1985), pode ter ocorrido (a exemplo de outros metais) em particulas coloidais finas o suficiente para passar pelas membranas $0,45 \mu \mathrm{m}$ utilizadas para filtração (KENNEDY et. al., 1974 in HEM, 1985).

Os valores de novembro de 1993 podem ser observados na Figura 33. A exemplo do sulfato, o pátio de enxofre já não contribui com ions $\mathrm{Fe}^{2+}$, confirmando a eficiência da medida de controle (fechamento do pátio com muro).

observa-se uma redução geral de concentração (vide curvas de 10, 50 e $100 \mathrm{mg} / \mathrm{l}$ ), inclusive com separação entre as plumas de poluição da área dos residuos (NW) e da área industrial $(S E)$. 
Apesar dos maiores valores de $\mathrm{Fe}^{2+}$ ocorrerem em aguas com $\mathrm{pH}$ baixo, não há uma correlação iinear direta entre estes parâmetros, possivelmente devido aos colóides ou formação do par iónico $\mathrm{FeSO}_{4}(\mathrm{aq})$, cuja solubilidade independe do pH HEM (1985). 


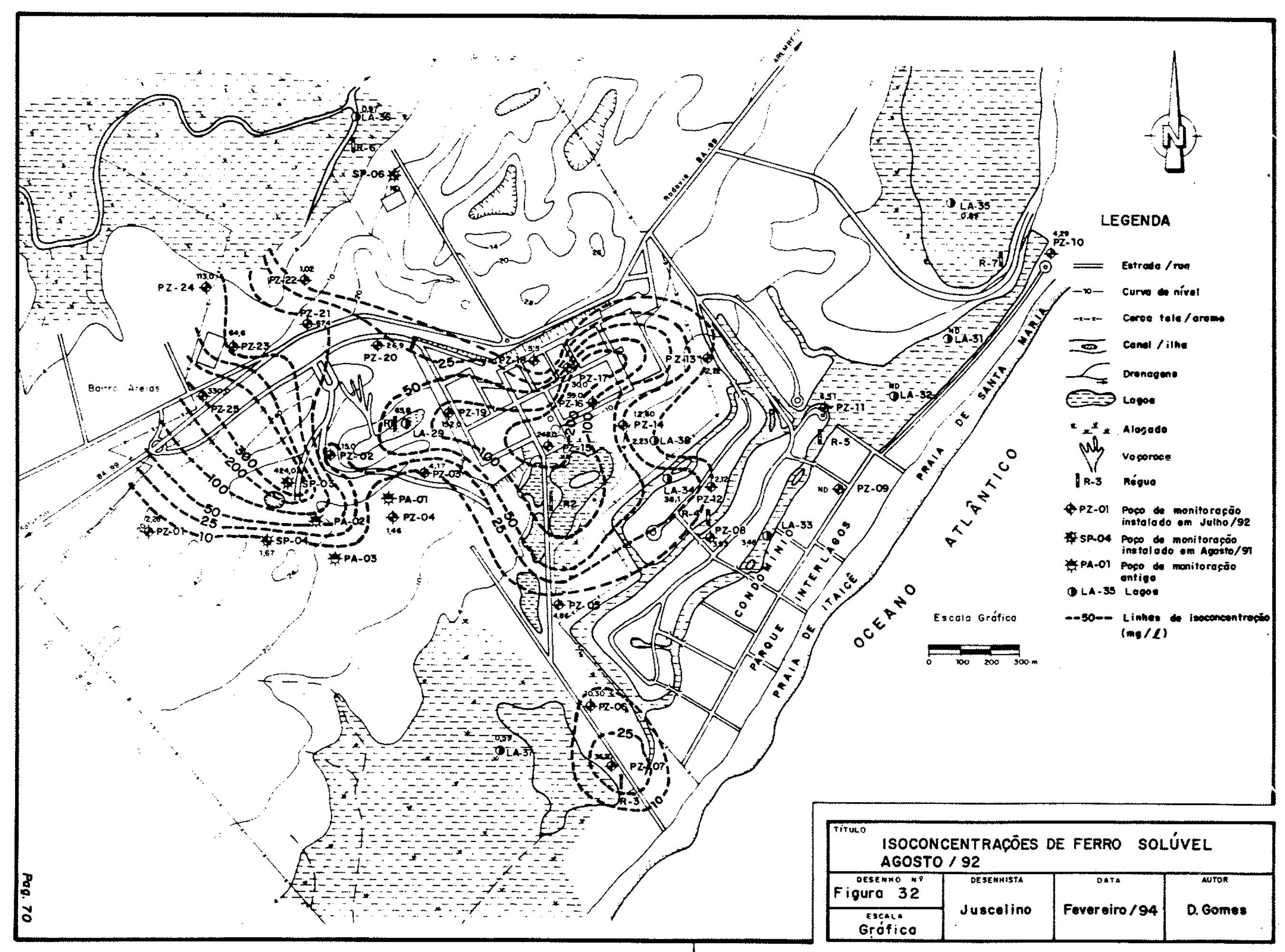




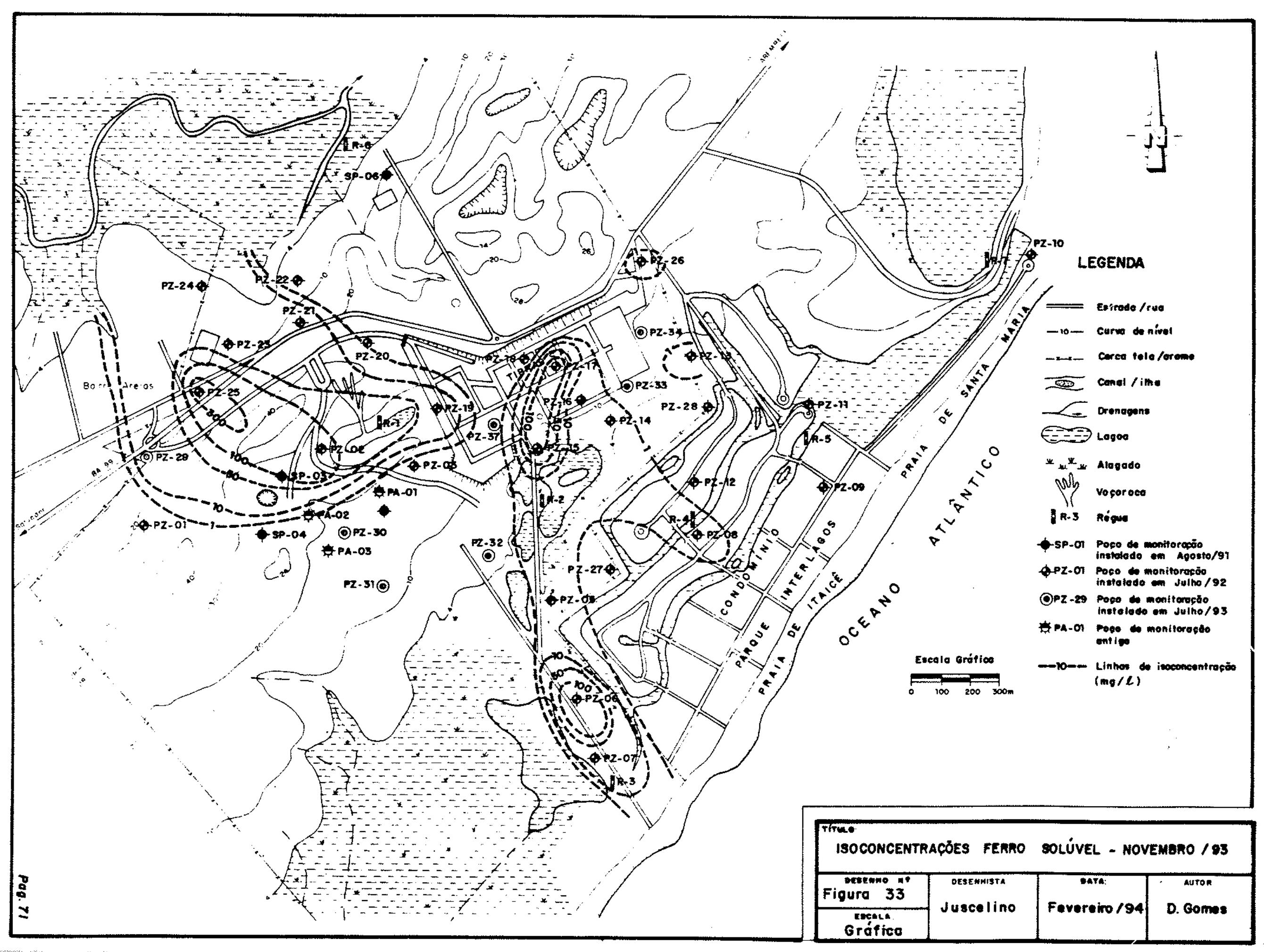


Os valores deste parametro variaram de $21 \mu \mathrm{s} / \mathrm{cm}$ a $96.700 \mu \mathrm{S} / \mathrm{cm}$ nas cinco campanhas, sendo uma medida da abilidade da agua em conduzir uma corrente elétrica, o que, por sua vez é função dos sais nela dissolvidos, principalmente (HEM, 1985).

A distribuição deste parâmetro em agosto de 92 e novembro de 93 encontram-se respectivamente nas Figuras 34 e 35, sendo similares à distribuição de sulfato, nestas datas.

A Figura 36 mostra a boa correlação obtida entre estes dois parâmetros, cujo coeficiente de correlação chegou a 0,90. Isto revela que a condutividade elétrica pode ser eficientemente usada para uma avaliação preliminar de casos similares a este. 


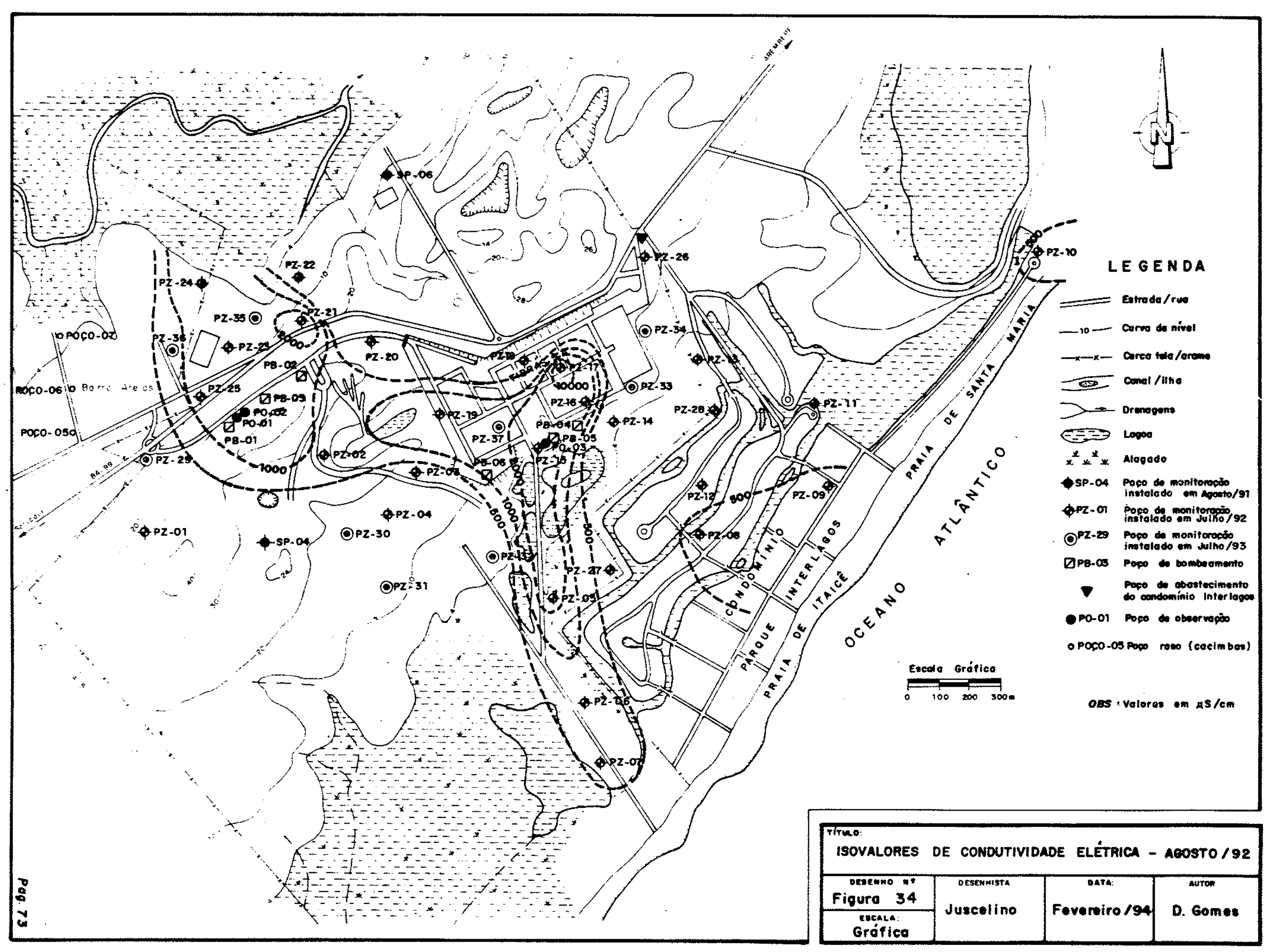




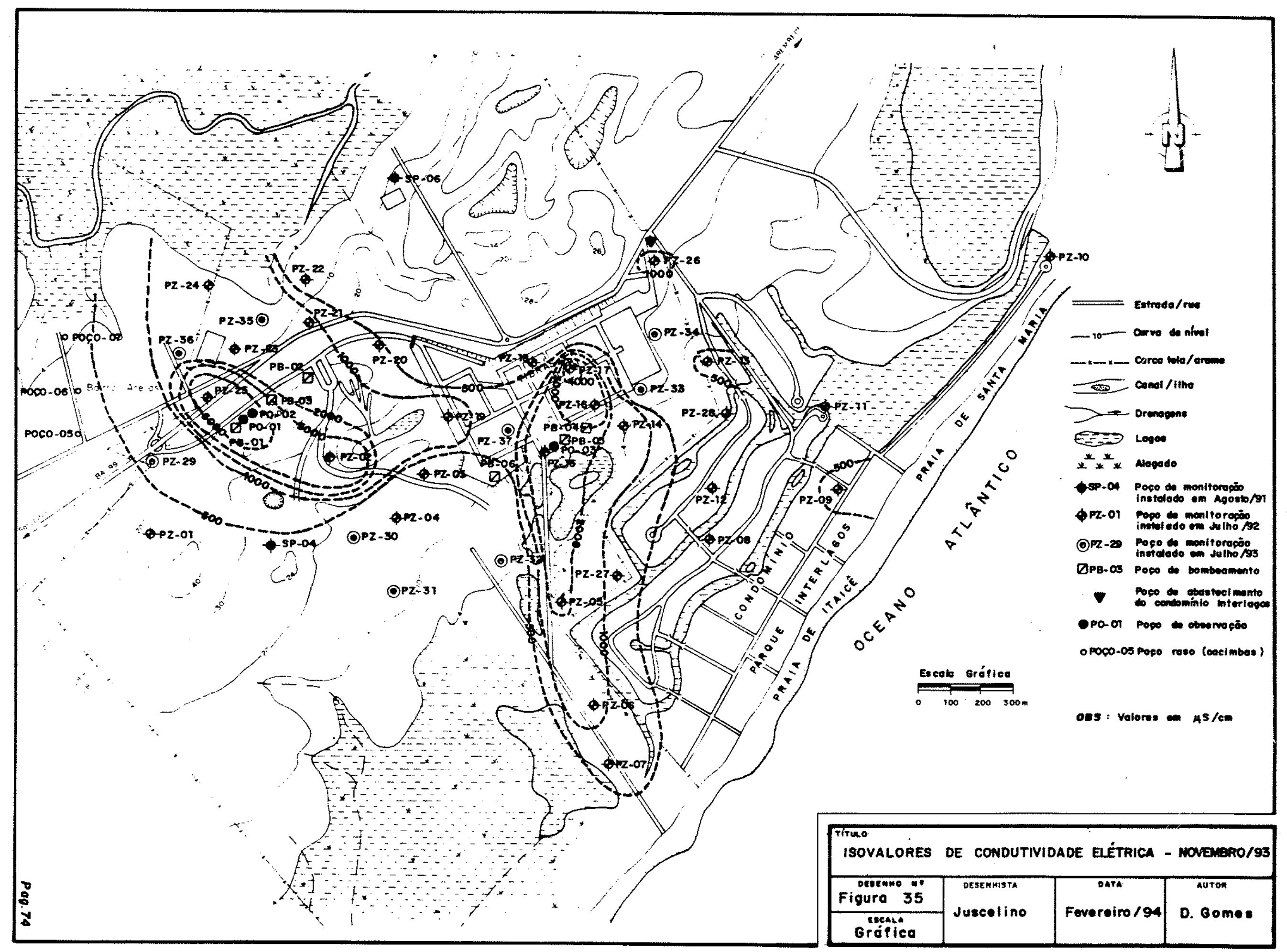


FIGURA 36 : CORRELACĀO ENTRE SULFATO E CONDUTIVIDADE ELÉTRICA

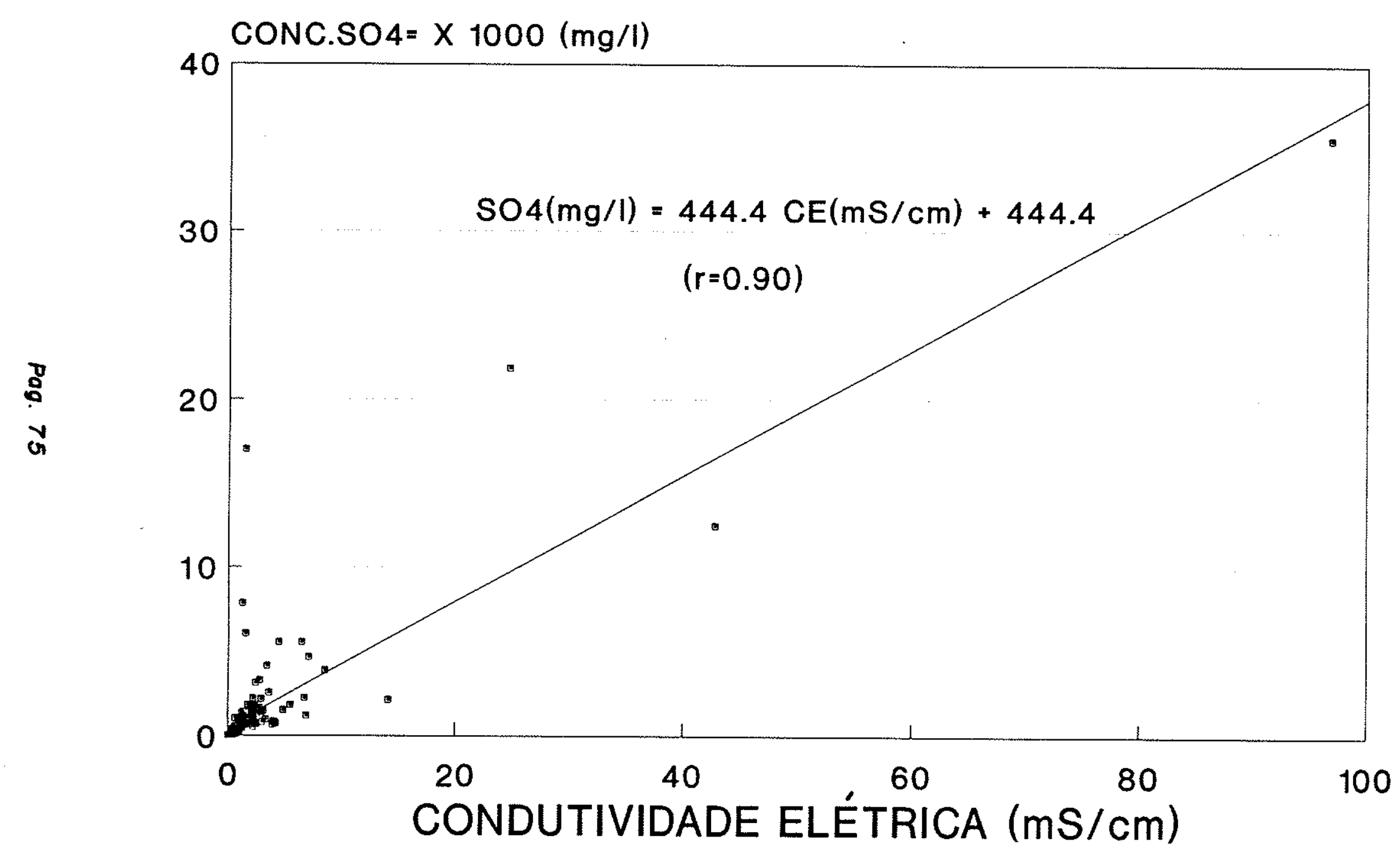


- Titânio

Apesar de ser o nono elemento mais abundante na crosta terrestre (KRAUSKOPF, 1972), principalmente formando minerais como rutilo, anatásio, ilmenita e outros, o Titânio é relativamente raro nas águas, sendo considerado como traço (nivel de $\mu \mathrm{g} / \ell$ ). A concentração média na crosta é estimada em 5.700 ppm (KRAUSKOPF, 1972), com médias de 4.380 ppm nas rochas igneas e $1.950 \mathrm{ppm}$ em arenitos (HEM, 1985).

A forma iônica deste elemento mais comum nas águas subterrâneas parece ser $\mathrm{TiO}^{2+}$ ou $\mathrm{Ti}(\mathrm{OH})_{2}{ }^{2+}\left(\mathrm{Ti}^{4+}\right)$, as quais somente ocorrem em águas fortemente ácidas (HEM, 1985). A solubilidade de formas menos estáveis de $\mathrm{TiO}_{2}$ podem ultrapassar $1 \mathrm{mg} / \mathrm{l}$, em faixas de $\mathrm{pH}$ menores que 2. Acima de $\mathrm{pH} 3$ a forma $\mathrm{Ti}(\mathrm{OH})_{2}$ (aq) foi proposta, segundo o mesmo autor. Esta última, a exemplo de outros metais, evoluem a cristais sólidos e apresenta solubilidade de $150 \mu \mathrm{g} / \mathrm{l}$ ( $\mathrm{pH}$ entre 4 e 8). Em ambientes extremamente ácidos e redutores, pode ocorrer $\mathrm{Ti}^{3+}$, porém a forma tetravalente $\left(\mathrm{Ti}^{4+}\right)$ é mais comumente encontrada.

A Figura 37 mostra que foram encontradas quatro áreas anômalas em agosto de 1992, cujas concentrações variaram entre 3,23 e $12,3 \mathrm{mg} / \mathrm{\ell}$.

A exemplo do ocorrido com o ferro, é provável que estas concentrações estejam super-estimadas devido à presença de particulas coloidais, finas o suficiente para não serem retidas pelas membranas $0,45 \mu m$ usadas na filtração (KENNEDY et.al., 1974 in HEM, 1985).

A presença destas quatro plumas de poluição isoladas mostra a baixa mobilidade deste ion, se comparada às plumas de sulfato, $\mathrm{pH}$ e $\mathrm{Fe}^{2+}$, por exemplo, que atingiram áreas bem maiores. 
As fontes deste composto são as mesmas já descritas anteriormente para outros compostos à exceção do pátio de enxofre, que não contribui com titânio. A área junto aos poços PZ-04 e PZ-03, tem sua origem ligada provavelmente a caminhos pavimentados com limalha de ferro e lama de ilmenita.

A área atingida pela poluição é de cerca de $650.000 \mathrm{~m}^{2}$, correspondendo a um volume de $195.000 \mathrm{~m}^{3}$, ou o equivalente a $1.600 \mathrm{t}$ deste Ion, provavelmente em grande parte na forma coloidal.

o titânio não é considerado tóxico, sendo inerte ao organismo humano na forma de $\mathrm{TiO}_{2}$, segundo a ORGANIZAÇÃO INTERNACIONAL DO TRABALHO (OIT), 1975. 


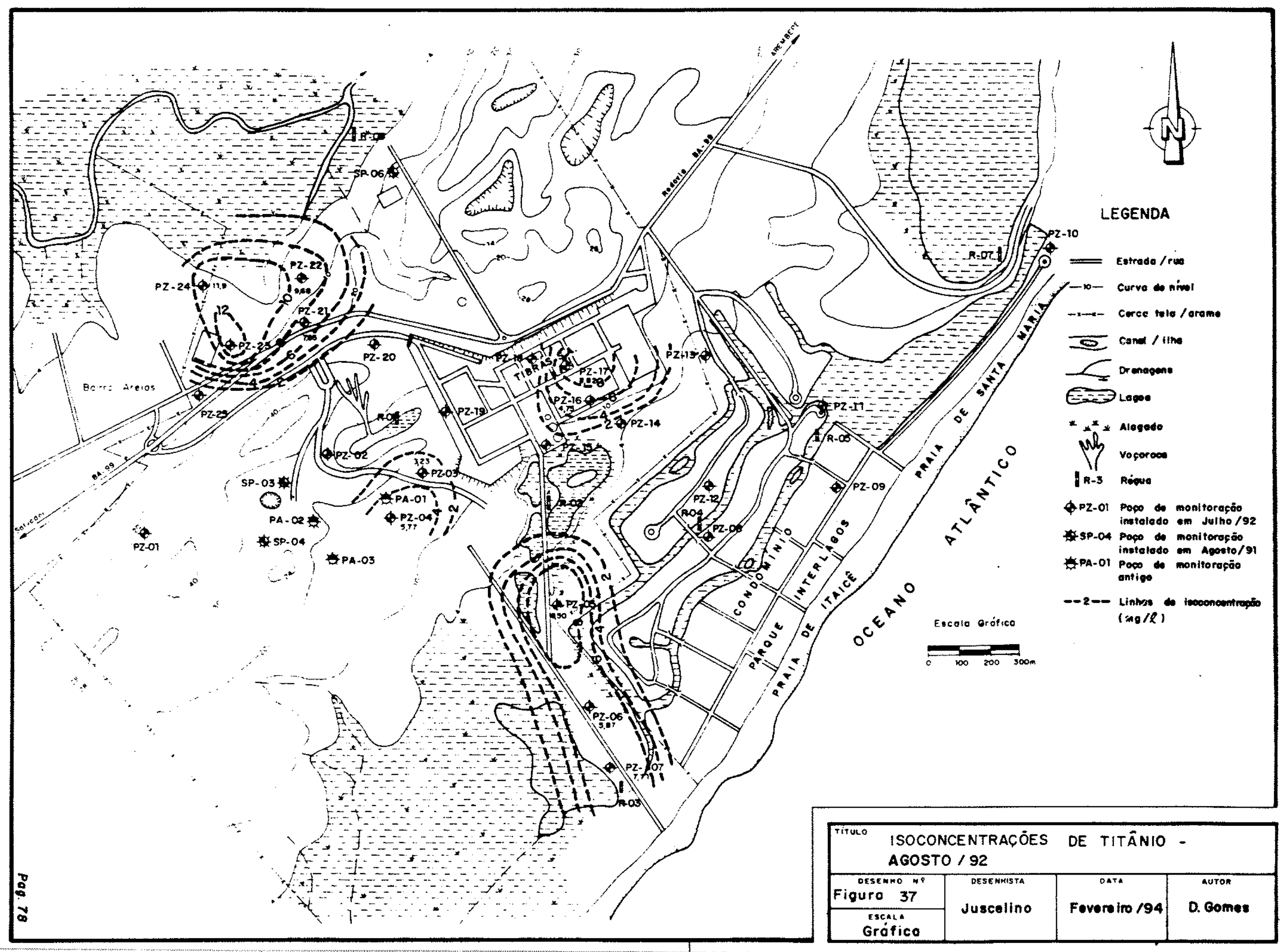


o aluminio foi detectado em três regiōes distintas, em agosto de 1992 (Figura 38), relacionadas aos residuos sólidos das dunas; área industrial, notadamente junto aos tanques de ácido sulfúrico, depósito de enxofre e tanque de efluentes (na saida do emissário); e junto ao antigo vazamento do emissário submarino $(P Z-05$ e $P Z-06)$.

Este ion nāo está presente nos residuos em concentraçōes relevantes, sendo oriundos da mobilização dos fons $\mathrm{Al}^{3+}$ trocáveis existentes nos sedimentos locais, devido ao caráter ácido das soluçōes poluidoras. O Ion $A \ell^{3+}$ predomina em soluções com $\mathrm{pH}$ inferior a 4, enquanto a forma $\mathrm{Al}(\mathrm{OH})_{4}^{-}$é mais expressiva a partir de $p H$ 7-8 (WUTKE in MONIZ, 1975). Entre $p H$ 4-8, predomina o $\mathrm{Al}(\mathrm{OH})_{3}$, insolúvel.

Complexos do tipo $\mathrm{AlSO}_{4}{ }^{+}$podem ser predominantes em soluções como as do local de estudo, ricas em sulfato (HEM, 1985).

Este fato poderia explicar a não correlaçāo entre pH e este Ion. Por exemplo, apesar da maior concentração de $\mathrm{Al}^{3+}$ ocorrer no poço de monitoração com mais baixo $p H(P Z-17, p H=1,0)$, outros pontos com elevadas concentrações aparecem em águas com pH relativamente alto ou vice-versa. Por exemplo: PZ-15; onde $[\mathrm{Al}]=88,9 \mathrm{mg} / \mathrm{l}$ e $\mathrm{pH}=4,5 ; \mathrm{PZ}-05$, onde $[\mathrm{Al}]=10,5 \mathrm{e}$ $\mathrm{pH}=7,5 ;$ ou no caso inverso, $\mathrm{PZ}-02$ onde $[\mathrm{Al}]=3,48 \mathrm{com}$ pH 2,5 .

A existência de colóides finos $(<0,45 \mu \mathrm{m})$ também poderia explicar esta ausência de correlação, conforme ocorre com outros metais. 
- aluminio não é táxico a seres humanos por ingestão, sendo inclusive usado na forma de hidróxido como anti-ácido estomacal. A fixação de limites recomendáveis para consumo humano $(0,1 \mathrm{mg} / \ell)$ se deve a efeitos principalmente organolépticos.

Entretanto, quando em concentração superior a $1 \mathrm{ppm}, \circ \mathrm{Al}^{3+}$ é tóxico à maioria das plantas cultivadas, afetando as funçōes biológicas das ralzes (WUTKE, in MONIZ, 1975). 


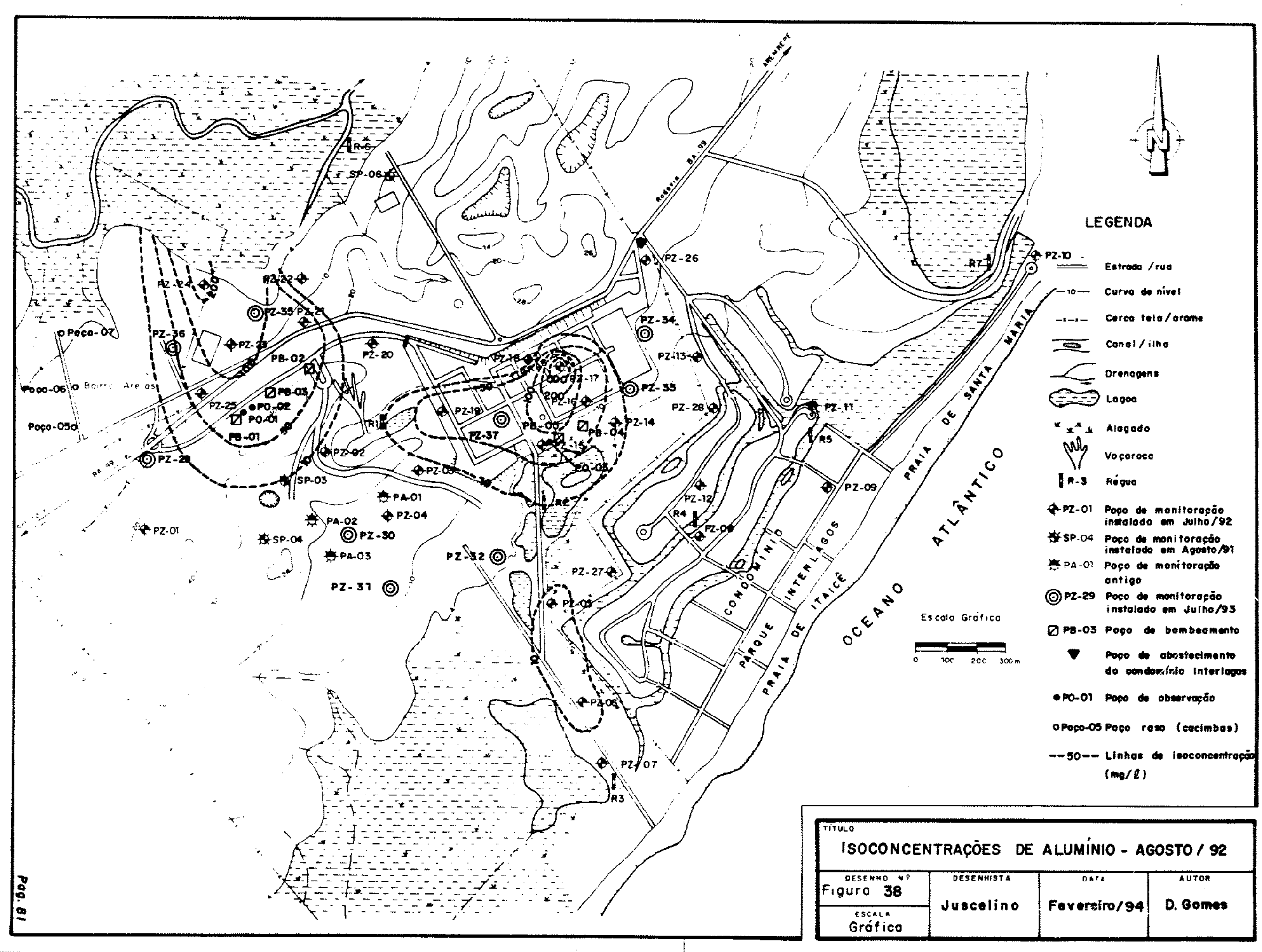




\section{- Manganês}

- manganês ocorre nas águas subterrâneas principalmente na forma reduzida $\left(\mathrm{Mn}^{2+}\right)$, tendendo a precipitar $\mathrm{em}$ meios oxidantes, na forma de óxidos de $\mathrm{Mn}^{4+}$. Águas ricas em sulfato, como neste caso, podem apresentar complexos do tipo $\mathrm{MnSO}_{4}(\mathrm{aq})$ (HEM, 1985).

Na área de estudo, foram encontradas em agosto de 1992 duas plumas principais, relacionadas aos depósitos de residuos nas dunas a oeste e às atividades industriais (pátio de enxofre e junto aos tanques de efluentes), além de um pequeno foco junto ao $P Z-07$.

As concentraçōes nesta época variaram entre 0,02 (PZ-04) e 23,8 $m g / \ell(P Z-15)$, sendo os valores regionais médios em torno de 0,1 $\mathrm{mg} / \ell$ (com variações de 0,02 a $0,35 \mathrm{mg} / \mathrm{\ell}$ ).

A exemplo do Aluminio e Ferro, não há correlação razoável com o $\mathrm{pH}$, provavelmente pelos mesmos motivos.

Os valores encontrados estão acima dos limites recomendáveis para consumo humano, estabelecidos devido principalmente a problemas estéticos e econômicos (precipitação de óxidos pretos em tubulações, etc.). o consumo médio diário de Manganês é estimado em $10 \mathrm{mg} / \mathrm{l}$, numa dieta normal, sendo considerado um nutriente essencial para alguns animais (BATALHA \& PARLATORE, 1977). Entretanto, a exemplo do $A l$, o $M n$ pode ser tóxico às plantas, em concentrações ao redor de $10 \mathrm{ppm}$ no solo e 1000 ppm nas folhas (WUTKE, in MONIZ, 1975). 
- Chumbo, Zinco, Cromo Hexavalente e Cobre

O chumbo $\left(\mathrm{Pb}^{2+}\right)$ foi encontrado em apenas 6 poços de monitoração, tendo ultrapassado os limites da NTA-60/OMS $(0,05 \mathrm{mg} / \mathrm{l})$ em apenas 2 pontos: $\mathrm{PZ}-02$ (área de residuos) e $\mathrm{PZ}-17$ (perda nos tanques de $\mathrm{H}_{2} \mathrm{SO}_{4}$ ). Como não está presente nos residuos, sua origem deve ser a partir da sua mobilização dos sedimentos locais. A concentração média deste composto é estimada em 16 ppm nas rochas igneas, 14 ppm em arenitos e $80 \mathrm{ppm}$ em folhelhos (HEM, 1985).

o zinco ocorre nas águas como $\mathrm{zn}^{2+}$, sendo bem mais solúvel que outros metais pesados (HEM, 1985). Na área de estudo, as concentrações em 1992 variaram entre 0,02 e 9,78 mg/ $\ell$ (SP-03), com somente um valor acima dos limites recomendáveis $(5 \mathrm{mg} / \mathrm{l})$. Suas origens são as mesmas do chumbo, pelas mesmas razões.

Apenas um poço de monitoração ultrapassou a concentração recomendável de cromo hexavalente $(0,05 \mathrm{mg} / \mathrm{l})$, junto ao pátio de enxofre (Pz-19), cuja origem é desconhecida. Em geral, a área apresentou valores muito baixos em agosto de 1992, entre 0,01 e $0,04 \mathrm{mg} / \mathrm{l}$.

o Ion Cobre $\left(\mathrm{Cu}^{2+}\right)$ apresentou valores modestos, entre 0,03 e 0,76 , com somente um ponto ultrapassando o limite de potabilidade de $1 \mathrm{mg} / \ell(P Z-25 ; 6,84 \mathrm{mg} / \mathrm{l})$, junto à área dos residuos. 
- Vanádio e Nióbio

Destes elementos, presentes nas areias ricas em ilmenita que servem de matéria prima para o processo industrial, apenas o vanádio foi detectado na área.

o comportamento geoquímico do vanádio é complexo, podendo existir três estados de oxidação estáveis em sistemas aquáticos $\left(V^{3+}, V^{4+}, V^{5+}\right)$, especialmente em águas ácidas (HEM, 1985). Entretanto, $o$ Ion $V^{5+}$ tende a predominar, formando anions complexos com oxigênio e hidróxidos, que podem associar-se a outros metais (p.ex. $\mathrm{Fe}^{2+}$ ), precipitando.

As concentraçōes de vanádio em agosto de 1992 variaram entre 0,017 e $0,844 \mathrm{mg} / \ell$ na área industrial e 0,001 e 0,372 mg/e na área dos residuos. Dos dez valores detectados, apenas 2 ultrapassaram os limites recomendáveis, em áreas restritas.

- Carbono orgânico Dissolvido

Este parâmetro, escolhido para identificar a influência dos compostos orgânicos provenientes dos residuos "domésticos", apresentou valores regionais relativamente elevados, devido à presença das areias orgânicas negras.

Os valores nas áreas baixas variaram entre 4,8 e 19,4 mg/ $\mathrm{e}$, com média de $11,2 \mathrm{mg} / \mathrm{l}$. Valores associados aos residuos (SP-03, $P Z-25, P Z-23$ e $P Z-24)$ situam-se entre 22,5 e 33,9 mg/l. os valores mais elevados foram encontrados na área industrial: $P Z-17,242 \mathrm{mg} / \ell$, ou 22 vezes o "background" e PZ-15, com 46,6 $m g / \ell$, ou 4 vezes o "background". Isto se deve provavelmente a vazamentos no sistema de esgotos da fábrica ou vazamentos de óleos minerais, já que não são usados compostos organoclorados no processo. Durante as sondagens, no entanto, não foram observadas fases oleosas livres na superficie do lençol freático. 
- Compostos Nitrogenados

Foram detectados apenas traços de nitritos (na forma de $\mathrm{N}-$ $\left.\mathrm{NO}_{2}\right)$ e nitratos $\left(\mathrm{N}-\mathrm{NO}_{3}\right)$, em geral muito inferiores aos limites de potabilidade, oriundos da oxidação da matéria orgânica dos residuos domésticos.

- Sulfeto e cloreto

A presença de Ions sulfeto é mais expressiva junto às áreas baixas, ricas em matéria orgânica natural, mostrando que nesta região, o ambiente é mais redutor (ou levemente oxidante) ocorrendo provavelmente na forma de $\mathrm{H}_{2} \mathrm{~S}(\mathrm{aq})$ já que o pH é inferior a 7, em geral (KRAUSKOPF, 1972)

Em 1992, o valor mais elevado (184 mg/l) ocorreu junto ao $\mathrm{PZ}-$ 05, situado em areias argilosas pretas ricas em matéria orgânica. Os demais valores variaram entre 2 e $10,4 \mathrm{mg} / \mathrm{l}$, sendo sempre inferiores nas areias de dunas, onde o ambiente é mais oxidante.

o Ion cloreto $\left(\mathrm{Cl}^{-}\right)$ocorre em toda a área, em concentrações na faixa de 8 a $107 \mathrm{mg} / \mathrm{\ell}$, com apenas um valor ultrapassando os $250 \mathrm{mg} / \mathrm{l}$ recomendados para consumo humano (3050 mg/ $/$ no $P Z-05)$.

As concentraf̧ões encontradas são normais em áreas próximas ao oceano. 
o Ion cloreto é um bom indicador de contaminações por depósitos de lixo domésticos, porém, tendo em vista os baixos valores encontrados nos poços de monitoração próximos aos residuos "domésticos", conclui-se que estes residuos pouco alteram a qualidade das águas subterrâneas locais. Este fato é corroborado pelos baixos valores de Carbono orgânico Dissolvido e compostos nitrogenados encontrados. 


\subsection{BALANÇO DE MASSA PRELIMINAR}

Para avaliar a necessidade de medidas de remediação na área dos residuos depositados nas dunas, foi feito um balanço de massa preliminar para o Ion $\mathrm{SO}_{4}{ }^{2-}$, onde assume-se que o mesmo não sofra efeitos de retardamento ou decaimento de concentração devido a efeitos de redução ou biodegradação, etc.

Dado o grande número de incertezas, os valores calculados devem ser considerados apenas como ordem de grandeza da dinâmica deste Ion no processo poluidor.

Em 1990, haviam cerca de $63.000 t$ de residuos industriais $e$ $18.700 t$ de limalha de $F e$ no local. A tabela mostra as quantidades em sais passiveis de serem lixiviados / solubilizados:

\begin{tabular}{|c|c|c|c|c|c|}
\hline $\begin{array}{l}\text { RESIDUO } \\
\text { INDUSTRIAL }\end{array}$ & $\begin{array}{c}\text { TOTAL DISPOSTO } \\
(t)\end{array}$ & \multicolumn{2}{|c|}{ COMPOSICYÃO } & $\begin{array}{c}\text { TOTAL DE } \mathrm{SO}_{4}^{2 \cdot} \\
(t)\end{array}$ & OBS.: \\
\hline Borra de Enxofre & 3.000 & $\stackrel{\mathrm{s}}{\mathrm{H}_{2} \mathrm{O}}$ & $\begin{array}{l}(60 x) \\
(40 x)\end{array}$ & $*$ & $\begin{array}{l}\text { - Não reage com a água, } \\
\text { en princípio }\end{array}$ \\
\hline Lama Industrial & 60.000 & $\begin{array}{c}\mathrm{H}_{2} \mathrm{SO}_{4} \\
\mathrm{FeSO}_{4} \\
\mathrm{TiOSO}_{4} \\
\mathrm{FeriO}_{3} \\
\mathrm{SiO}_{2}+\mathrm{H}_{2} \mathrm{C}\end{array}$ & $\begin{array}{l}(20 x) \\
(7 x) \\
(6 x) \\
(30 x) \\
(37 x)\end{array}$ & 16.568 & $\begin{array}{l}\text { - sais de } \mathrm{SO}_{4} \text { são } \\
\text { sotúveis }\end{array}$ \\
\hline Limalha de fe & 18.700 & $\begin{array}{c}\mathrm{Fe}(\mathrm{OH})_{3} \\
?\end{array}$ & $(100 x)$ & - & $\begin{array}{l}\text { Fe lixiviável em meio } \\
\text { ácido }\end{array}$ \\
\hline Total & 81.700 & - & & 16.568 & - \\
\hline
\end{tabular}

ou seja, existiam em 1990 cerca de 16.600 toneladas de ions sulfato passiveis de serem lixiviados às águas subterrâneas. 
Para avaliar a taxa de liberação de sulfatos ao aquifero e ao rio Capivara Grande, foram inicialmente quantificados os totais destes ion existentes nas 5 campanhas de amostragem realizadas, cujos resultados encontram-se na Tabela 8 (Volume Contaminado $x$ Concentração Média, segundo NYER, 1992).

\begin{tabular}{|c|c|c|c|c|c|c|c|c|}
\hline \multirow{2}{*}{ MES } & \multicolumn{2}{|c|}{ ÁREA $\left(m^{2}\right)$} & \multicolumn{2}{|c|}{ VOLUME $\left(m^{3}\right)$} & \multicolumn{2}{|c|}{ CONC. MÉdIA $(\mathrm{mg} / \mathrm{l})$} & \multicolumn{2}{|c|}{ MASSA $(t)$} \\
\hline & A.I. & R.S. & A.1. & R.S. & A.I. & R.S. & A.I. & R.S. \\
\hline AGO/92 & 350.000 & 400.000 & 105.000 & 120.000 & 7.380 & 2.380 & 775 & 286 \\
\hline JAN/93 & 620.000 & 530.000 & 187.500 & 159.000 & 1.593 & $1.484(*)$ & 299 & $235(*)$ \\
\hline MAL /93 & 620.000 & 600.000 & 186.000 & 180.000 & 1.367 & 2.554 & 254 & 460 \\
\hline JUL/93 & 475.000 & 595.000 & 142.500 & 178.500 & 3.108 & 1.576 & 443 & 281 \\
\hline NOV $/ 94$ & 720.000 & 630.000 & 216.000 & 189.000 & 4.664 & 1.127 & 1.007 & 213 \\
\hline
\end{tabular}

Obs:

$A I=$ Area Industrial (Pluma Sudeste)

RS = Area de Residuos Sótidos nas Dunas (Pluma Noroeste)

* = Valor sub-estimado devido a danos no PZ-23

No balanço de massa, a massa que entra no aquifero (advinda dos residuos), subtraida da massa que sai do aquifero (para o rio Capivara Grande e áreas alagadiças contiguas), é igual à massa acumulada no aquifero. Para evitar efeitos de remoção de massa pelo bombeamento da lagoa inter-dunas, foram escolhidas as análises de agosto de 92 e maio de 93, para avaliar o acumulo de massa:$$
M_{i}-M_{0}=\left(M_{\text {mad }}-M_{\text {ago }}\right) / 9, \text { onde }
$$ 
o valor de Mo foi calculado através da Lei de Darcy, onde:

$$
Q_{0}=K i A \text {, onde }
$$

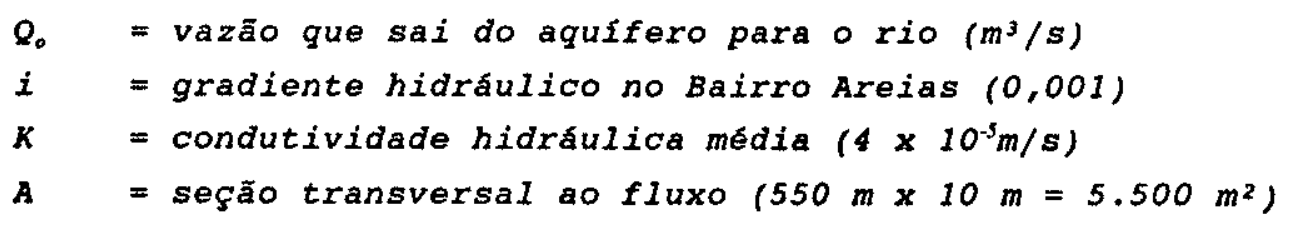

A massa $M_{0}$ foi então calculada pela multiplicação do fluxo $Q_{0}\left(2.2 \times 10^{-4} \mathrm{~m}^{3} / \mathrm{s}\right.$, ou $570 \mathrm{~m}^{3} /$ mês $)$ pela concentração média de saida do sistema, nas amostragens de agosto/92, janeiro e julho/93, medidas no $\mathrm{PZ}-24\left(2.000 \mathrm{mg} / \mathrm{l} \mathrm{SO}_{4}^{2-}\right)$. Desta forma, $M_{0}=1,1 t / m e ̂ s$. Esta taxa deve estar super-estimada, uma vez que as concentraçōes médias de saída devem ser menores lateralmente.

Portanto, a taxa de liberação de ions sulfato ao aquifero, corresponde a (da equação 5):

$$
\begin{aligned}
M_{i}-1,1= & (460-286) / 9 \\
M_{i}=20,5 t / m e ̂ s, & \text { ou } 246 \text { t/mês, considerando taxas médias fixas, para } \\
& \text { efeitos de ordem de grandeza. }
\end{aligned}
$$

Em 1990 haviam cerca de $16.568 t$ lou $16.076 t$ em 92) de sulfatos potencialmente lixiviáveis. Assumindo-se a taxa fixa de Iiberação de 246 t/ano de $\mathrm{so}_{4}{ }^{2-}$ dos residuos para as águas subterrâneas, o tempo total previsto para lixiviação total seria da ordem de 65 anos, a partir de 1992. 
Por outro lado, assumindo-se que a lixiviação de sulfatos apresente decaimento exponencial, ou seja, a taxa varia com a variação da massa dos residuos, têm-se:

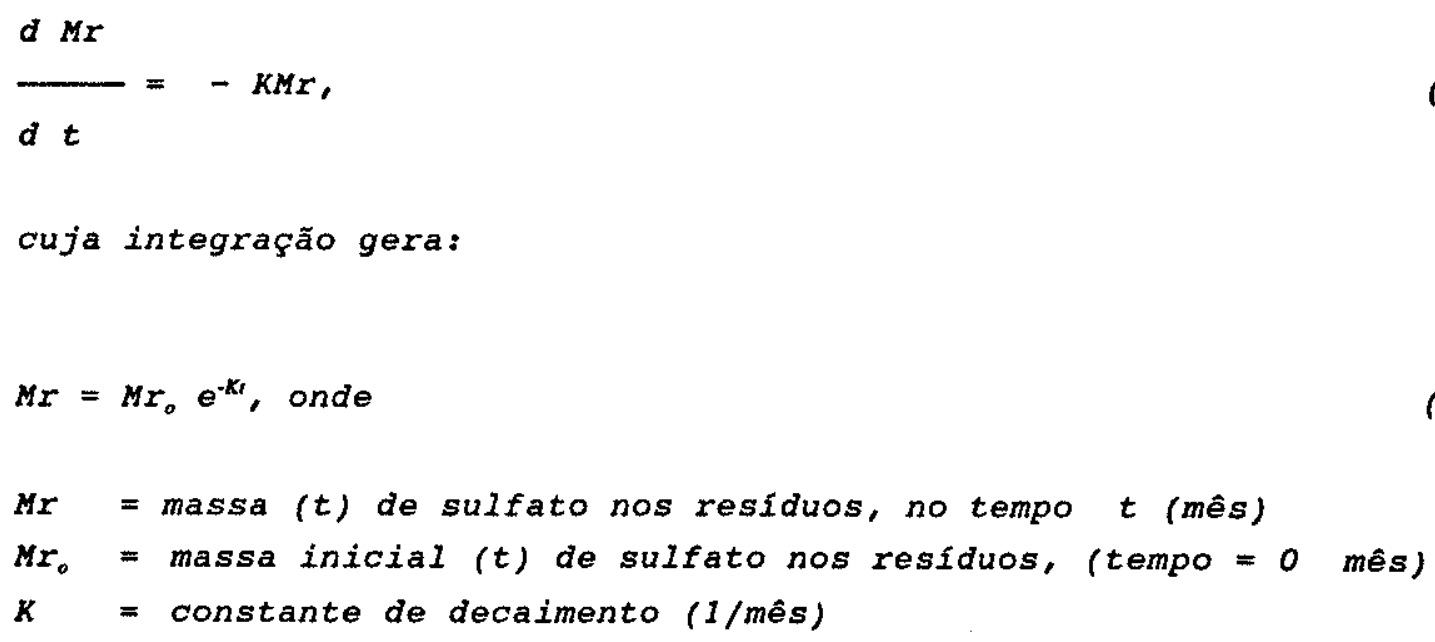

Para calcular esta constante de decaimento, assume-se que a massa que sai dos residuos é igual à massa que entra no aquifero, sendo a massa acumulada no aquifero igual a :

d Mag

$-=K M r-M o$, onde

$d t$

d Maq

$d t$

$K M r=$ massa que entra no aquífero, no tempo (t) (da equação 7$) ; e$

Mo = massa que sai do aquífero para o rio Capivara Grande (vide equação 5 )

A integração desta equação fornece:

$\Delta M a q=M x_{0}\left(1-e^{-K_{i}}\right)-M_{0} t$ 
Como $\triangle M a q=M_{m a i}-M_{\text {ago }}=460-286=174$ toneladas acumuladas em $t=9$ meses, a equação (10) assume a seguinte. forma:

$174=16568\left(1-e^{-9 x}\right)-1,1 \times 9$

Ou seja, $K=0,00124 \mathrm{mês}^{-1}$

A meia-vida dos residuos é então calculada por (segundo CLEARY, in PORTO et.al., 1991):

$T_{k}=\frac{0,693}{K}$

ou seja, $T_{\frac{1}{2}} \cong 559$ meses ou aproximadamente 47 anos.

Estes cálculos, ainda que imprecisos, devido às incertezas inerentes ao balanço de massa, mostram que mesmo após 22 anos no local, os residuos continuariam a contaminar as águas subterrâneas locais a niveis relevantes por décadas, caso medidas de remediação não fossem tomadas. 


\section{MEDIDAS DE RECUPERAÇÃO AMBIENTAL}

\subsection{OBJETIVOS E ESTRATEGTA}

Os principais objetivos das açōes corretivas adotadas são:

- recuperar a qualidade das águas subterráneas e das águas superficiais, principalmente nas áreas habitadas próximas (Bairro Areias e Condominio Interlagos);

- reduzir ao máximo as fontes de contaminação ao subsolo; e

- recuperar a paisagem da área, degradada pelos residuos industriais.

o processo poluidor ocorre de duas formas principais: através da lixiviação de sais e metais pela ação das águas de chuva nos residuos das dunas; e através de perdas de ácido sulfúrico e lixiviação de residuos dispostos no pátio de enxofre, na área industrial.

Numa primeira fase, os residuos foram isolados por camadas impermeabilizantes (processo também chamado "Encapsulamento Hidráulico"), sendo também separadas as principais fontes industriais (Fase I).

Dada as altas taxas de recarga e as altas velocidades de escoamento das águas subterrâneas, a simples eliminação das fontes de poluição já ocasionaria uma melhora importante na qualidade das águas subterrâneas, porém, a recuperação provavelmente demoraria um tempo expressivo, já que as concentrações eram elevadas. 
Portanto, para acelerar este processo de recuperação, optou-se pela instalação de um sistema adicional de bombeamento das aguas subterrâneas, no sentido de remover as partes centrais das plumas de poluição e reduzir a migração destas para as áreas habitadas (Fases II e III).

Atualmente, o processo encontra-se na fase III, de avaliação de resultados e definição de eventuais medidas adicionais.

A Figura 39 mostra a estratégia de ação adotada. 
IIGURA 39 - MEDIDAS DE RDUEDIACAO : ESTRATEGIA DL ACAO

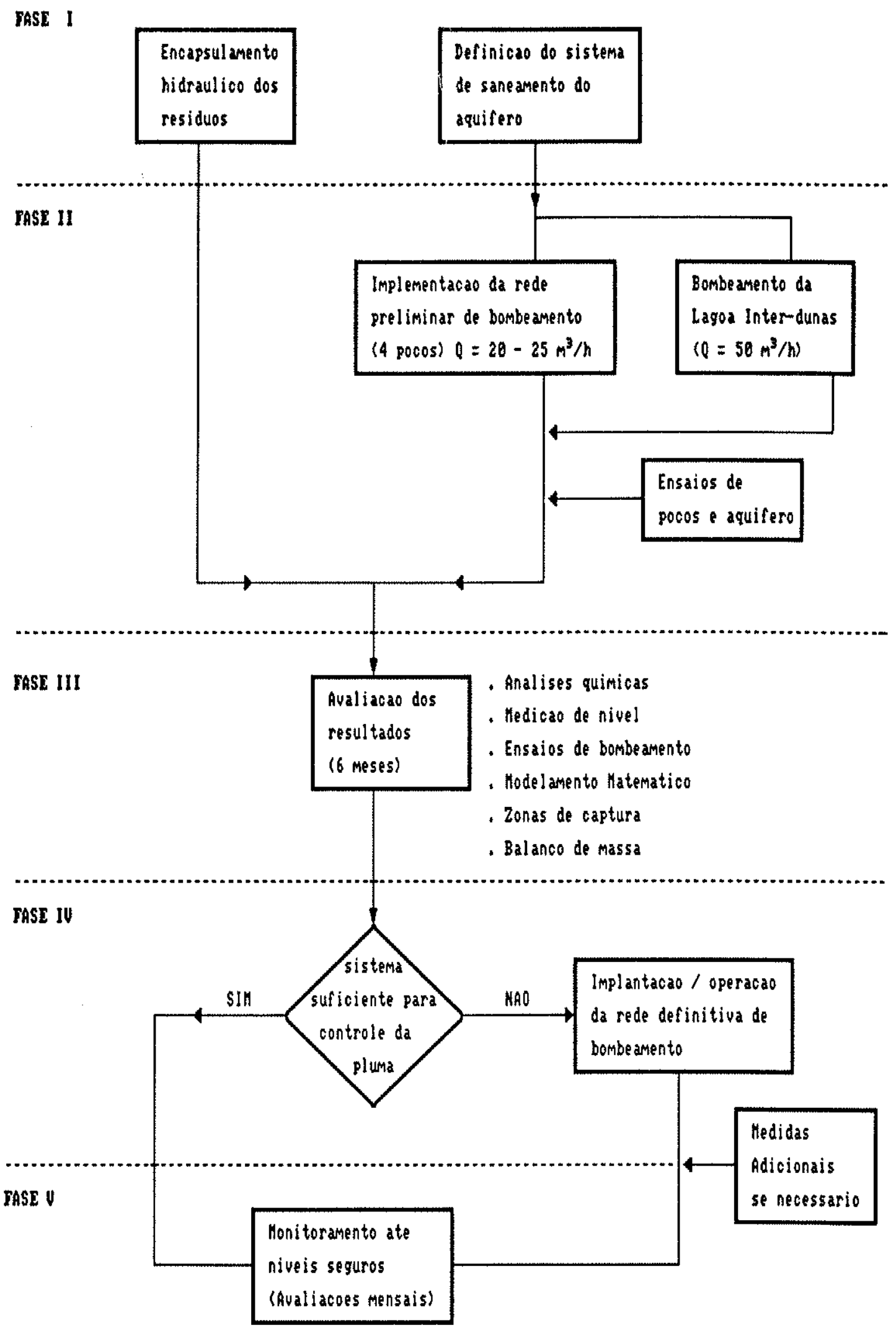




\subsection{ELIMINAÇÃO DE FONTES DE CONTAMINAÇĀO}

\subsubsection{Impermeabiliząão dos Residuos}

Também conhecido por "encapsulamento hidráulico", baseia-se no seguinte princípio: a lixiviação dos poluentes se dá através da infiltração das águas das chuvas, portanto, o isolamento do contato direto chuva-residuos irá eliminar (ou reduzir drasticamente) as cargas poluidoras às águas subterrâneas.

Outra medida cabivel seria a remoção dos residuos e transporte até um destino final (aterro industrial, por exemplo). Entretanto esta alternativa apresentava várias desvantagens, tais como: alto custo, impacto devido ao transporte (emissōes atmosféricas, acidentes, etc.) periodo de remoção muito longo e aumento considerável do total de remover, já que além da remoção dos residuos industriais e domésticos, haveria que ser retirada uma parte da zona não-saturada provavelmente contaminada e, principalmente, haveria a possibilidade de re-mobilização das dunas semi-móveis, pela ação dos ventos. Além disso, seria necessária a realização e aprovação de projeto de aterro doméstico e industrial, já que não haviam instalações disponiveis para volumes tão grandes.

Desta forma foi feita inicialmente uma redução da área dos residuos, já que haviam vários focos pouco espessos de residuos espalhados pelo terreno. Estes focos foram removidos e colocados sobre $\circ$ foco principal $\left(27.200 \mathrm{~m}^{2}\right)$, para posterior impermeabilização com camadas argilosas, mais eficiente em áreas menores (BÜCHLER \& POLL, in CSD-GEOKLOCK, 1993). 
Da mesma forma, as areias e residuos que haviam deslizado da voçoroca para o interior da lagoa inter-dunas foram removidos e re-depositados na áxea da voçoroca e também impermeabilizados (área de $7.000 \mathrm{~m}^{2}$ ). Duas barreiras de muros de gabiōes foram usadas para dar maior estabilidade ao local, evitando novas desestabilizações.

A impermeabilização dos residuos foi feita em três camadas de 0,2 $m$ de espessura, acima de uma primeira camada com $0,1 \mathrm{~m}$ (regularizadora), totalizando $0,7 \mathrm{~m}$. o material usado foi uma mistura de solos argilosos com $2 \%$ de bentonita (em peso), para garantir condutividades hidráulicas saturadas inferiores a $1 \times 10^{-9} \mathrm{~m} / \mathrm{s}$.

Estas camadas foram homogeneizadas com arado de disco e compactadas, segundo um rigoroso controle de compactação, através de ensaios tecnológicos de grau de compactação e umidade. Além disso, cerca de 30 amostras indeformadas foram retiradas em vários locais e nas 3 camadas. A permeabilidade média obtida foi de $1,9 \times 10^{-9} \mathrm{~m} / \mathrm{s}$ (mediana $1,0 \times 10^{-9} \mathrm{~m} / \mathrm{s}$ ), com $63 \%$ dos valores na faixa de $2,2 \times 10^{-10}$ a $9,9 \times 10^{-10} \mathrm{~m} / \mathrm{s}$.

Acima das camadas de impermeabilização, foi usado o mesmo solo argiloso não compactado $(0,4 \mathrm{~m}$ de espessura) e finalmente, areias de dunas $(0,2$ a $0,3 \mathrm{~m})$. O objetivo destas camadas é o de proteger as camadas de impermeabilização contra rachaduras devido a ressecamento, através de dois princípios. Primeiramente, a camada de areia armazena as águas de chuva, lentamente sendo drenadas pelo caimento de $3,5 \%$ do terreno ao sistema de drenagem superficial, mantendo a umidade. 
Em segundo lugar, a longo prazo, caso ocorram fisisuras na impermeabilização, as mesmas serão preenchidas pelas partículas da mesma camada argilosa superior recuperando-a naturalmente, sem criar espaços com fraçōes grosseiras. Este princípio de autopreenchimento foi descrito por HORN (1992), mostrando-se eficiente em estudos realizados na Universidade de Munique, Alemanha.

A Figura 40 mostra as camadas de impermeabilização e cobertura utilizadas.

Como pode ser observado, na área dos residuos domésticos $\left(23.000 \mathrm{~m}^{2}\right)$, foi adotada uma camada de brita entre o residuo e a cobertura impermeabilizante, cuja função principal é drenar os gases eventualmente produzidos, transferindo-os a drenos e poços de captação de polietileno de alta densidade, podendo no futuro ser instalado um bio-filtro. Entre a brita e a impermeabilização usou-se manta geotêxtil para separação física. Entre os residuos industriais e os residuos domésticos, foi feito um dique de argila de até $4 \mathrm{~m}$ de profundidade de $2 \mathrm{~m}$ de largura média, para fins de separação dos residuos.

Além do controle tecnológico de compactação e ensaios de permeabilidade, foi instalado um sistema de controle de infiltração na área da voçoroca, logo abaixo da impermeabilização. Este é composto de uma manta de polietileno de alta densidade de 1,5 mm de espessura e caimento central de 3 \% para um tubo do mesmo material (diâmetro $50 \mathrm{~mm}$ ). A área ocupada é de $25 \mathrm{~m}^{2}$. Caso haja infiltração através da camada impermeabilizante, este sistema permitirá sua coleta e análise, através de drenagem a uma caixa coletora. 


\section{Figuro 40 - CORTE ESQUEMÁTICO DOS SISTEMAS DE IMPERMEABILIZAÇĀO}

\section{COBERTURA DO ATERRO DOMÉSTICO}

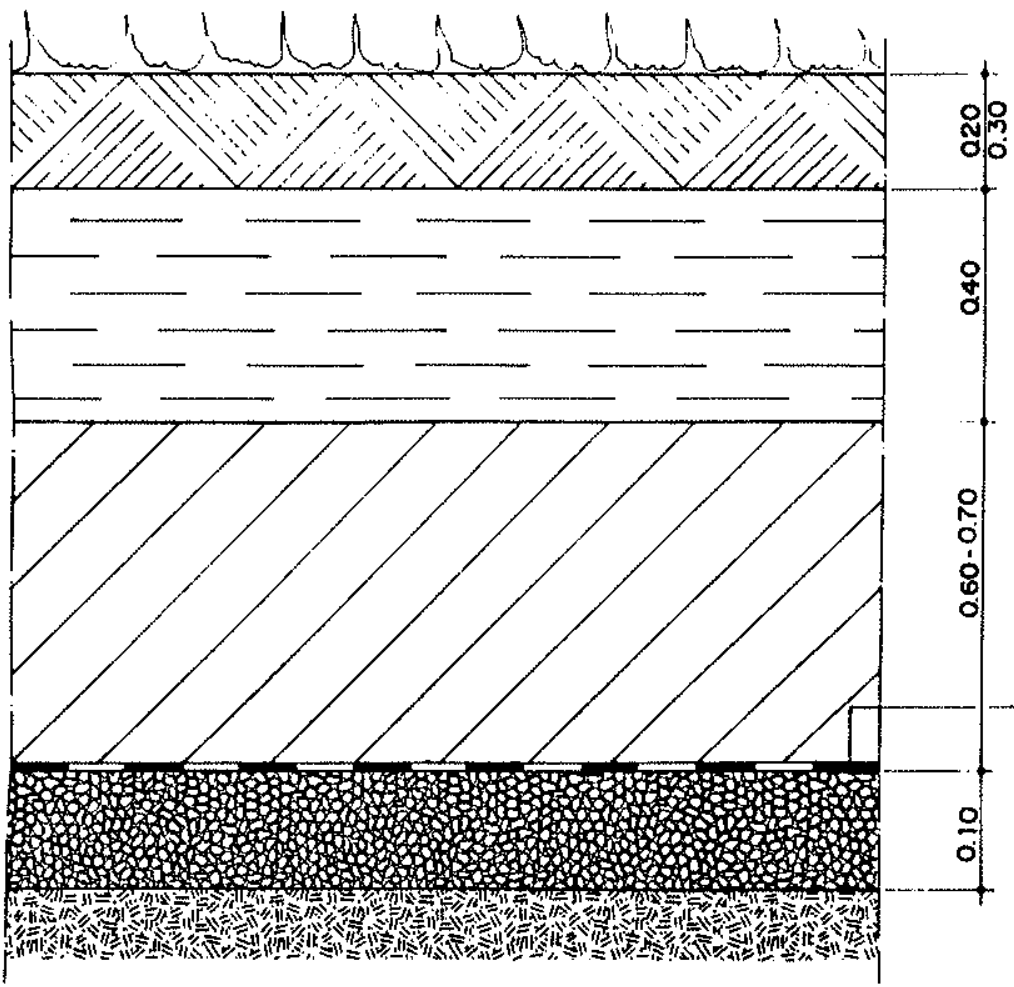

plantas nativas

AREIA

CAMADA IMPERMEABILIZANTE

ARGILA $\left(K \leqslant 1.10^{\circ} \mathrm{m} / \mathrm{s}\right)$

GEOTÊXTLL (BIDIM OP 2O)

BARREIRA CAPILAR (BRITA 2)

RESÍDUOS DOMÉSTICOS

\section{COBERTURA DO ATERRO INDUSTRIAL}

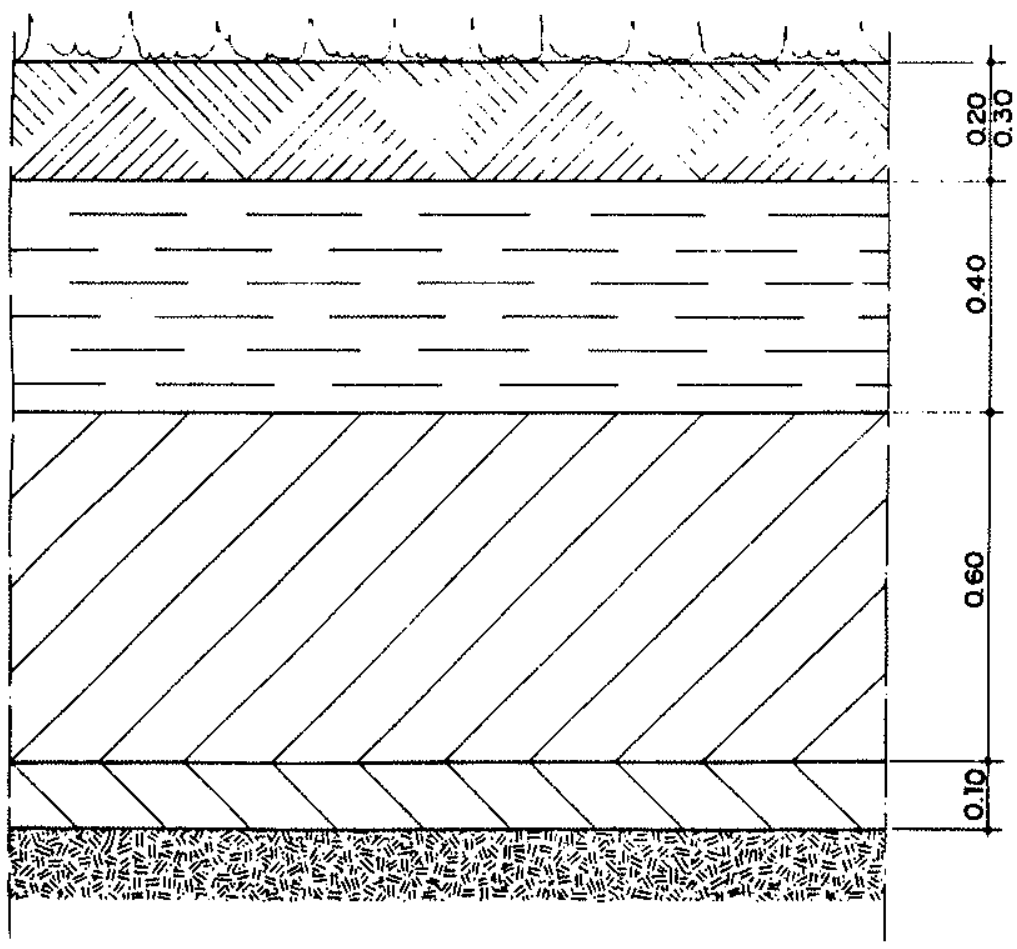

Pog. 98
Plantas nativas

AREIA

SOLO COBERTURA ARGILOSO

CAMADA IMPERMEABILIZANTE ARGILA $\left(K \leqslant 1.10^{-9} \mathrm{~m} / 0\right)$

CAMADA REGULARIZANTE ARGILA $\left(K \leqslant 1.10^{\circ} \mathrm{m} / \mathrm{s}\right)$

RESIOUOS INDUSTRIAIS

in CSO/OEOKLOCK (1993) 


\subsubsection{Eliminação de Fontes Industriais}

A fim de eliminar as principais fontes de poluição dentro da área industrial foi reparado o sistema de canaletas e tubulações na área de tancagem de ácido sulfúrico. Além disso a base dos tanques foi concretada e circundada por muros de concreto. Da mesma forma, foram removidos $0,10 \mathrm{~m}$ de areias impregnadas com óleos na área de tancagem de óleo diesel.

No pátio de enxofre, foram removidos os residuos antigamente dispostos e fechados os muros de contenção.

As emissōes gasosas, devido à queima de óleo combustivel nas caldeiras, principalmente, estão em processo de redução de até 85 \% em $S_{x}$, através da implantação de sistema de oxidação por via úmida (FINK, 1993).

\subsection{RECOMPOSTÇÃO DA PATSAGEM}

Acima das áreas recompostas, foi iniciado um trabalho de recomposição paisagística, através da seleção e plantio de mudas de espécies nativas da região.

Para tanto, o solo arenoso foi inicialmente coberto com folhas de palmeira, para evitar a erosão eólica-pluvial, protegendo as espécies plantadas e ajudando a criar um substrato para seu crescimento.

Foi tomado um cuidado especial para evitar a introdução de plantas com raizes profundas, que poderiam danificar a impermeabilização.

Atualmente, várias espécies já estão se desenvolvendo satisfatoriamente. 


\subsection{BOMBEAMENTO E DESTINO FINAL DAS AGUAS CONTAMINADAS}

\subsubsection{Bombeamento da Lagoa Inter-dunas}

o Bombeamento da Lagoa contaminada teve infcio efetivo em meados de maio de 1993, após uma rápida fase de testes em janeiro do mesmo ano. Por ser uma área de surgência das águas subterrâneas, - bombeamento da lagoa permitiu a retirada de grandes vazóes de agua contaminada.

As vazōes de bombeamento foram, em média, de $100 \mathrm{~m}^{3} / \mathrm{h}$, o que produziu um rebaixamento de aproximadamente $2,5 \mathrm{~m}$ no nivel d'água, com um raio de influência aproximado de $300 \mathrm{~m}$, com rebaixamentos observados nos poços $P Z-19(0,41 \mathrm{~m}$ de rebaixamento), $P Z-20(0,36 \mathrm{~m})$ e $P Z-02(0,07 \mathrm{~m})$, o que pode ser visto na Figura 17 (capitulo 3.2.2.).

A partir de outubro de 1993, a vazão foi diminuida para $50 \mathrm{~m}^{3} / \mathrm{h}$, devido à época de seca e problemas na capacidade do emissário submarino, sendo esta considerada a vazão média ótima.

- volume total bombeado chegou a aproximadamente $420.000 \mathrm{~m}^{3}$ de águas contaminadas. 


\subsubsection{Instalação de Poços de Bombeamento}

Foram instalados 6 poços tubulares com o objetivo de bombear as aguas subterrâneas contaminadas, cujo desenho e localizaçōes encontram-se descritos no item 2.3. (Figuras 5 e 6). A distancia entre os poços foi de $150-200 \mathrm{~m}$, para evitar interferências.

o objetivo destes poços é o de impedir ou minimizar a migração das partes mais concentradas das plumas de poluição para as áreas habitadas, respectivamente Bairro Areias ( $P B-01, P B-02$ e PB-03) e Condominio Interlagos (PB-04, PB-05 e PB-06). Além disso, 0 rebaixamento do lençol freático propiciará um aumento nas taxas de recarga locais, estimadas em $400 \mathrm{~mm} / \mathrm{ano}$, favorecendo a diluição da poluição.

Os ensaios de bombeamento (vide item 3.2.3., Tabela 3) mostraram que os poços $P B-01,02$ e 03 apresentaram vazões muito pequenas (inferiores a $1 \mathrm{~m}^{3} / \mathrm{h}$ ), sendo descartados para fins de bombeamento.

Para contornar este problema nesta área, levando-se em consideração que as camadas mais permeáveis situam-se nas porçōes mais superficiais do aquifero, foi construido um poço-dreno horizontal de $100 \mathrm{~m}$ de largura, conforme mostra a Figura 41 (vide localização na Figura 42), cuja vazão está estimada entre 10 e $15 \mathrm{~m}^{3} / \mathrm{h}$, segundo testes preliminares de vazão durante 0 desenvolvimento.

A escavação foi feita com retro-escavadeira, sendo que a profundidade máxima alcançada para o posicionamento dos drenos foi de $1 \mathrm{~m}$ abaixo da superficie de saturação.

A Tabela 9 mostra o resumo das características de produção dos poços de bombeamento, cujo inicio de operação é previsto para março de 1994. 


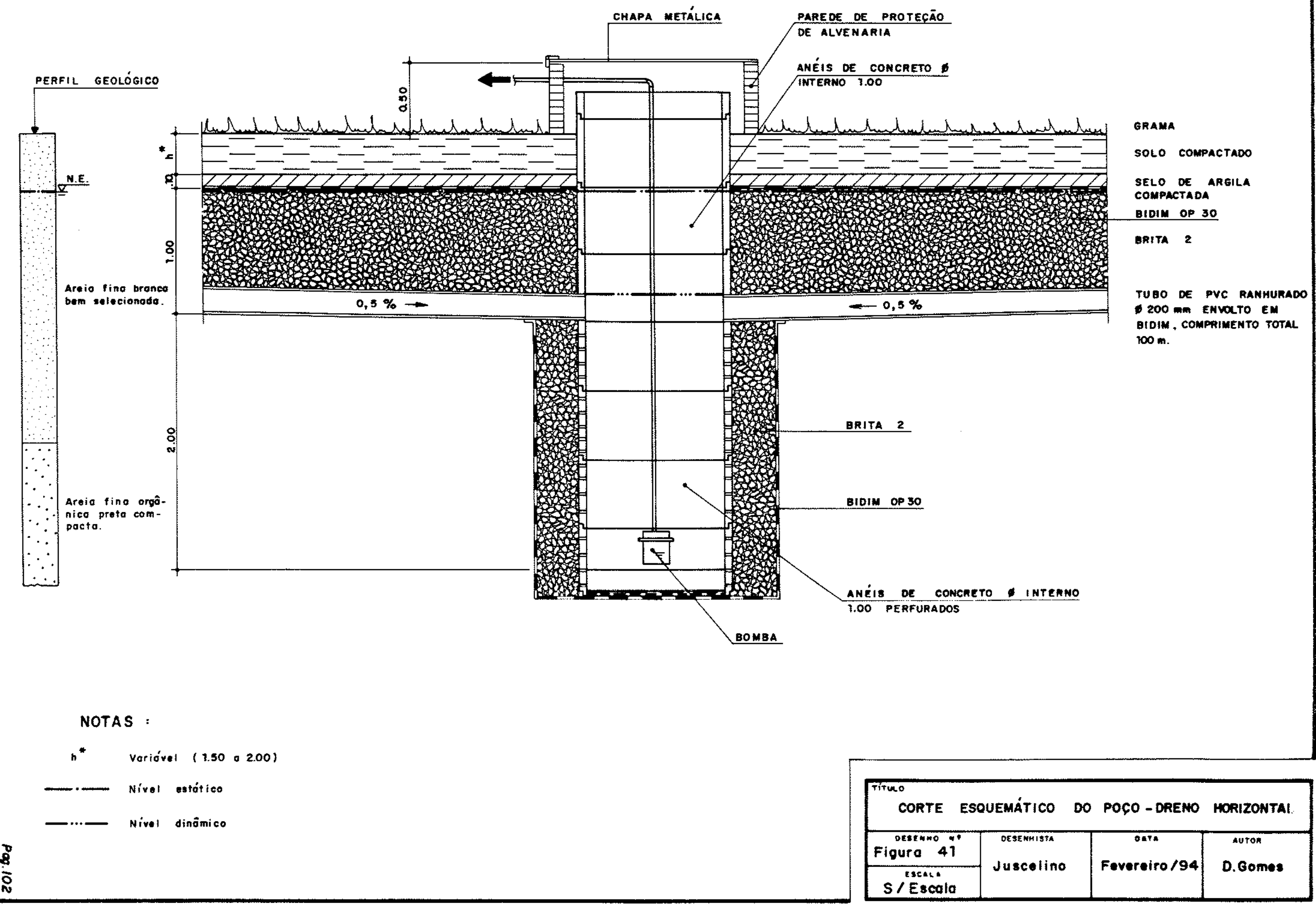




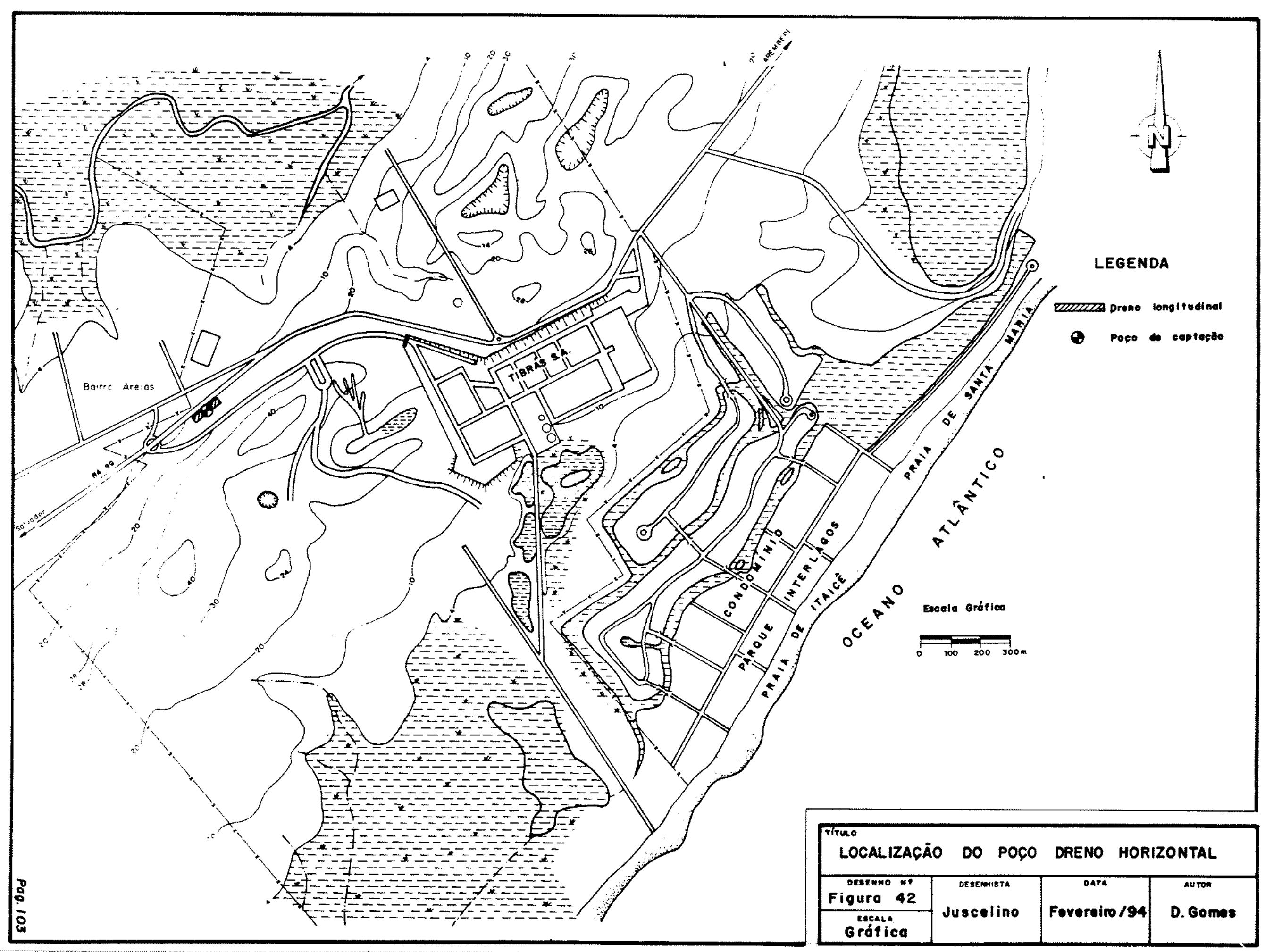




\begin{tabular}{|c|c|c|c|c|c|c|}
\hline & $\begin{array}{l}\text { N.E. } \\
\text { (m) }\end{array}$ & $\begin{array}{l}\text { N.D. } \\
\text { (m) }\end{array}$ & $\begin{array}{l}\text { Q TESTE } \\
\left(m^{3} / h\right)\end{array}$ & $\begin{array}{l}\text { a ortmo } \\
\left(m^{3} / h\right)\end{array}$ & $\begin{array}{c}\text { RAIO DE INFLUENCIA } \\
\text { (m) }\end{array}$ & OBSERVAÇŐES \\
\hline PB -01 & 14,5 & 20,3 & 0,96 & - & - & Improdut ívo \\
\hline$P B=02$ & 23,0 & 28,3 & 0,12 & - & $\cdot$ & Improdut ivo \\
\hline$P B \cdot 03$ & 16,1 & 22,7 & 0,10 & - & $\cdot$ & Improdut ivo \\
\hline PB $=04$ & 2,0 & 5,0 & 2,25 & 1,0 & 30 & c. Interlagos \\
\hline$P B-05$ & 1.0 & 4,3 & 12,00 & 9.0 & 120 & c. Interlagos \\
\hline$P B=06$ & 1.9 & 5,1 & 2,00 & 1,5 & 45 & c. Interlagos \\
\hline POÇO- DRENO & 2,0 & 3,0 & $\begin{array}{ll}8,00 & \\
(*)\end{array}$ & $\begin{aligned} 10-15 \\
(* *)\end{aligned}$ & $(* * *)$ & Bairro Areias \\
\hline
\end{tabular}

* - vazão durante o desenvolvimento

** - estimado

*** - raio minimo (= comprimento dos drenos) 
4.4.3. Destino Final das Aguas Bombeadas

As Aguas Bombeadas, em total aproximado de $70-75 \mathrm{~m}^{3} / \mathrm{h}\left(50 \mathrm{~m}^{3} / \mathrm{h}\right.$ da lagoa e 20-25 $\mathrm{m}^{3} / \mathrm{h}$ dos poços de bombeamentol, serão lançadas ao mar, através de emissario submarino já existente. o impacto deste lançamento será monitorado mensalmente.

Em principio, as concentraçōes de sulfato são comparáveis às da água do mar $(1.000-1.500 \mathrm{mg} / \ell)$ e $O$ baixo $\mathrm{pH}$ deverá ser prontamente neutralizado, devido à alta capacidade-tampão das águas salinas. o Fe e outros metais não podem ser considerados a rigor contaminantes importantes, já que suas concentraçōes não são tão elevadas e serão amplamente diluílas na saída do emissário. 


\subsection{AVALIAÇÃO PRELTMINAR DAS MEDIDAS ADOTADAS}

A impermeabilização dos residuos (ou "encapsulamento hidráulico") foi concluida em 19/09/93 e o sistema de bombeamento das aguas contaminadas somente entrou parcialmente em operação (águas da lagoa) em meados de maio de 1993.

Como a ultima amostragem data de novembro de 1993, o sistema de remediação está efetivamente em andamento há 2,5 meses para a impermeabilização dos residuos e 5,5 meses para o bombeamento da lagoa. Portanto, está ainda em fase inicial de operação, o que impossibilita uma avaliação mais detalhada, sendo necessárias novas amostragens para tal.

No entanto, estas açōes remediadoras conjuntas parecem ter provocado algumas melhorias expressivas na região do Bairro Areias (oeste da área de estudo), principalmente um expressivo aumento do $\mathrm{pH}$ médio, correspondendo a aproximadamente $70 \%$ de recuperação nas concentrações do fon $H^{+}$(vide item 4.3.2. pH). Da mesma forma, os sulfatos mostraram forte decaimento, assim como a condutividade elétrica, conforme mostram as Figuras $43(P Z-25)$ e $44(P Z-24)$ situados nesta área. Apenas o $\mathrm{Fe}^{2+}$ não mostra sinais de melhora no $\mathrm{PZ}-25$, provavelmente devido a efeitos de retardamento (adsorção).

Por outro lado, a poluição industrial aumentou nas ultimas 2 campanhas (julho e novembro de 1993) (vide item 3.5.), principalmente devido a perdas na área dos tanques de ácido sulfúrico, cujo sistema de canaletas e tubulaçōes deveria ser rigorosamente inspecionados e reparados.

o sistema de bombeamento da lagoa já removeu cerca de $420.000 \mathrm{~m}^{3}$. Como a concentração média foi de $639 \mathrm{mg} / \ell$ de $\mathrm{SO}_{4}{ }^{2-}$, houve uma remoção de aproximadamente $270 \mathrm{t}$ deste Ion, proveniente em parte da área de residuos e também da área industrial. 
os poços de bombeamento, assumindo-se taxas de $20 \mathrm{~m}^{3} / \mathrm{h}$ e concentrações de $\mathrm{SO}_{4}{ }^{2-}$ de 1.000 - $1.500 \mathrm{mg} / \mathrm{l}$, serăo capazes de remover até $175.000 \mathrm{~m}^{3} / \mathrm{ano}$, ou o equivalente a aproximadamente 175-260 t/ano. Juntamente com o bombeamento das lagoas, que pode remover em torno de $430.000 \mathrm{~m}^{3} / a n o$ ou cerca de 270 t/ano, chega-se a um total de remoção de aproximadamente 450 - $530 \mathrm{t} / \mathrm{ano}$, contra aproximadamente $1.200 \mathrm{t}$ existentes no aquifero. Apesar destas taxas serem apenas ordens de grandeza, ja que as concentraçōes tendem a reduzir com o tempo, pode-se afirmar que a recuperação do aquifero será bastante rápida, caso as fontes industriais sejam efetivamente eliminadas. 
FIGURA 43 : EVOLUÇĀO TEMPORAL - PZ25

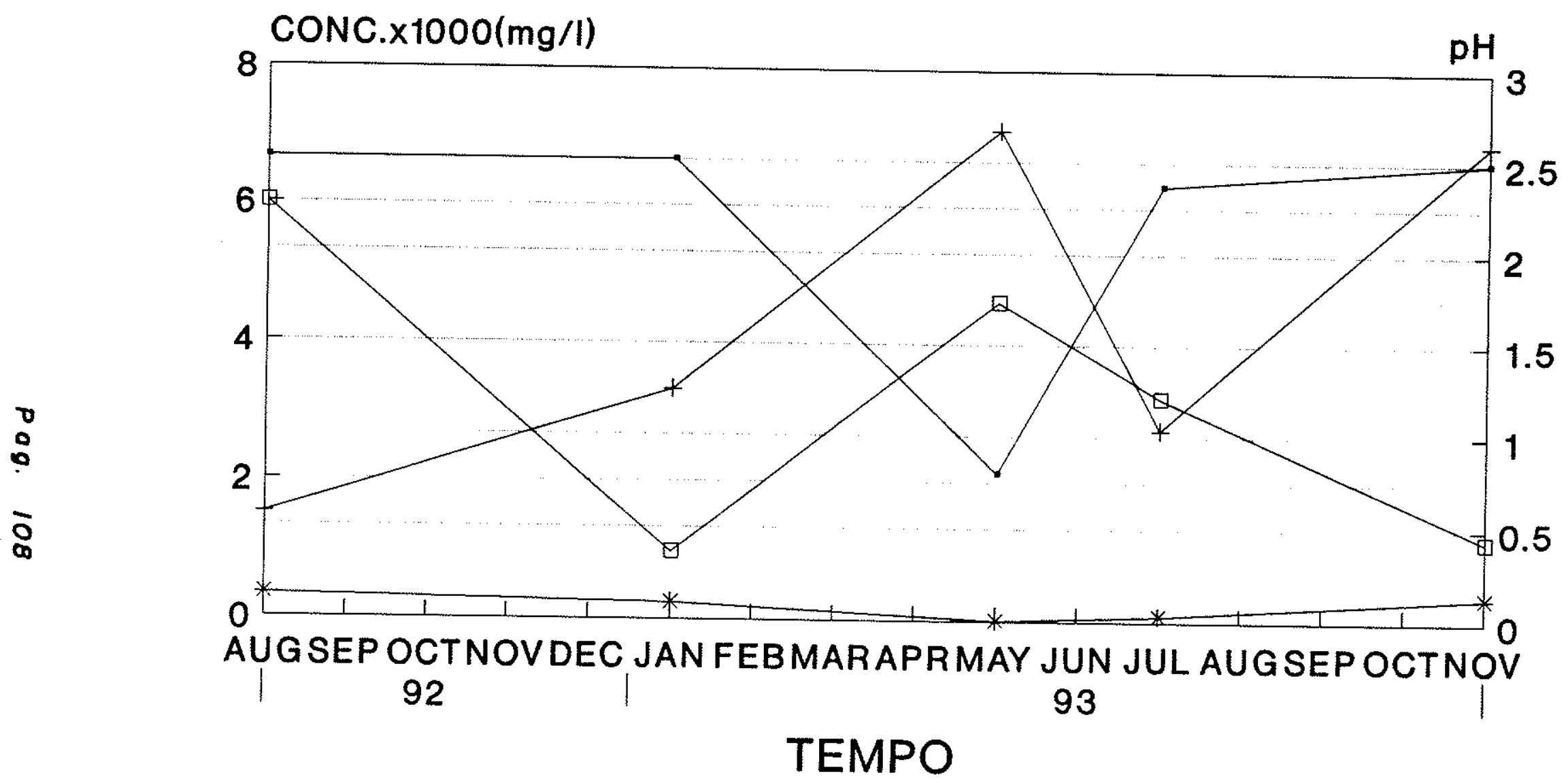

\section{LEGENDA}

$\rightarrow \mathrm{pH} \rightarrow$ C.E. $(\mathrm{mS} / \mathrm{cm}) \rightarrow \mathrm{Fe} \mathrm{2}^{2} \rightarrow$ SO4-- 
FIGURA 44 : EVOLUÇĀO TEMPORAL - PZ24

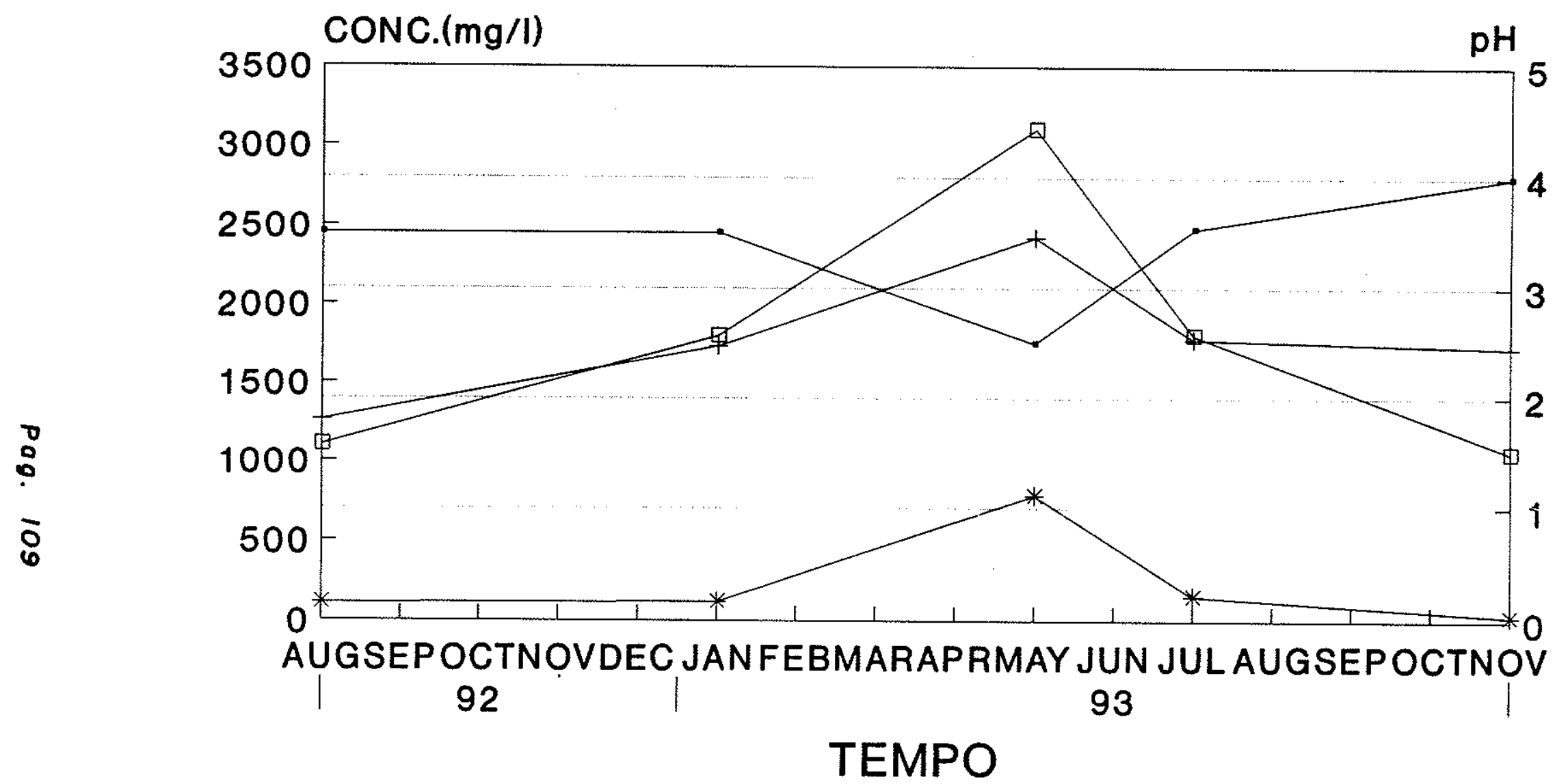

\section{LEGENDA}

$\because \mathrm{pH} \rightarrow$ C.E. $(\mathrm{mS} / \mathrm{cm}) \quad$ * Fe 2+ $\square \mathrm{SO} 4--$ 


\section{CONCLUSÕES}

- o principal aquifero $10 c a l$ é formado por areias finas inconsolidadas, por vezes organicas e/ou cimentadas por óxidos de Fe, assentadas discordantemente sobre solo de alteração de Embasamento Cristalino pré-Cambriano e sobreposto por areias de dunas bem selecionadas. Possui carater predominantemente livre, porém pequenas camadas argilosas podem provocar um efeito local de semiconfinamento.

- As velocidades de escoamento são relativamente elevadas, variando entre aproximadamente 60 e $690 \mathrm{~m} / \mathrm{a}$, de acordo às diferentes litologias e gradientes hidráulicos. As permeabilidades variam de $5 \times 10^{-7}$ a $6 \times 10^{-4} \mathrm{~m} / \mathrm{s}$, com média de $1,1 \times 10^{-4} \mathrm{~m} / \mathrm{s}$. As aguas subterrâneas movem-se em direção ao rio Capivara Grande, à noroeste e ao mar a sul-sudeste, havendo um divisor d'água situado nas dunas.

- Os resultados das análises químicas mostram que as perdas de ácido sulfúrico na área industrial e os residuos dispostos indevidamente nas dunas litorâneas causaram um impacto ambiental no aquifero freático e águas superficiais locais, principalmente no que diz respeito ao baixo $\mathrm{pH}$, sulfato, ferro solúvel e outros metais pesados.

- Foram identificadas duas plumas de poluição principais: uma junto ao Bairro Areias, a noroeste da área de estudo, migrando em direção ao rio Capivara Grande e outra a sudeste, migrando em direção ao mar. A primeira foi ocasionada pelos residuos dispostos nas dunas e a segunda principalmente devido às perdas de poluentes na área industrial. 
- As concentraçōes de vários sons estão acima dos limites recomendáveis para consumo humano em extensa área. Além disso, a acidificação do meio provocou a liberação de metais tóxicos às plantas, tais como o aluminio e manganés.

- As sondagens elétricas, apesar da dificil execução nos topos das dunas devido à alta resistividade das areias secas, mostraram uma boa correlação com os dados das perfurações. Da mesma maneira, o caminhamento elétrico foi bastante eficiente no mapeamento preliminar das aguas contaminadas apesar de algumas interferências com crostas limoniticas/solos organicos, sendo fortemente recomendável em casos similares.

- o Ion sulfato apresentou a maior distribuição espacial ao longo das campanhas de amostragem, mostrando estar menos sujeito a efeitos de retardamento que os ions $\mathrm{H}^{+}, \mathrm{Fe}^{2+}, \mathrm{Mn}^{2+}$ e $\mathrm{Al}^{3+}$. Este fato confirma que o sulfato é o parâmetro mais indicado para avaliação da extensão do front poluidor.

- Os parâmetros "in situ" também foram considerados bons indicadores das plumas de poluição. Além do $p H$, a condutividade elétrica apresentou boa correlação com a distribuição de sulfato, sendo recomendável para avaliaçōes preliminares rápidas.

- Não houve correlação razoável entre pH e os metais pesados, - que pode ser explicado pela presença de colóides finos, que atravessam as membranas $(0,45 \mu \mathrm{m})$ utilizados na filtração. outra explicação possivel seria através da formação de complexos dos metais pesados com o Ion sulfato (FeSO 4 (aq), $\mathrm{MnSO}_{4}(\mathrm{aq}), \mathrm{AlSO}_{4}^{+}(\mathrm{aq})$, cuja solubilidade independe do $\mathrm{pH}$. 
- o balanço de massa feito a nivel preliminar para o ion sulfato mostrou que os residuos dispostos no solo poderiam contribuir com taxas elevadas deste ion ao aquifero por várias décadas, caso medidas de remediação nāo fossem tomadas.

- As medidas de remediação adotadas, que incluem a impermeabilização dos residuos com camadas argilosas, recuperação e estabilização da voçoroca, bombeamento da lagoa inter-dunas, instalação de poços de bombeamento e recuperação da paisagem com plantação de espécies nativas, mostraram sinais de recuperação na área oeste (Bairro Areias), sendo, no entanto necessários novos dados para confirmação definitiva de tendências. Dada a elevada dinâmica de recarga/descarga da região, espera-se uma recuperação também rápida.

- Por outro lado, pelo menos uma fonte de poluição industrial é ainda ativa (vazamentos nas tubulações de ácido sulfúrico) o que provocou uma elevação de concentração na pluma sudeste (em sentido ao mar) na última amostragem. Recomenda-se investigar e reparar esta fonte imediatamente, sob pena de sacrificar o cronograma de recuperação da qualidade do aquifero nesta área. 


\section{REFERÊNCIAS BIBLIOGRÁFICAS}

BATALHA, B.L. \& PARLATORE, A.C. - 1977 - Controle de Qualidade da Agua para Consumo Humano. Bases Conceituais e operacionais. CETESB/BNH/ABES, $198 \mathrm{pp}$. São Paulo,

CAIRNEY, T. (Ed.) - 1987 - Reclaiming Contaminated Land. Blackie \& Son Lim. 260 pp. Glasgow, Inglaterra,

CETESB - 1988 - Guia de Coleta e Preservação de Amostras de Agua. AGUDO, E.G. (Coord.), 150 pp. São Paulo.

CPM - 1980 - Mapa Geológico do Quarentenário Costeiro do Estado da Bahia, Escala 1:250.000.

CSD-GEOKLOCK - 1993 - Recuperação das Dunas - Relatório Final. Relatório não Publicado. 43 pp. São Paulo.

DAVIS, A. e RUNNELLS, D.D.- 1987 - Geochemical Interactions Between Acidic Tailings Fluid and Bedrock : Use of the Computer Model MINTEQ. Apllied Geochemistry, Vol. 2:231-241.

ENVIRONMENT CANADA - 1986 - Muskoka Symposium on ACidic Precipitation, September 15-20, 1985. Water Quality Bulletin, Vol. 11 (4): 218-220.

FINK, J. - $1993-\mathrm{SO}_{2}$ Emission Reduction Through the use of the "Humid Oxidation Process". $3^{\text {rd }}$ International Conf. on Waste Manegement in the Chemical and Petrochemical Industries - New technologies and Practices for Waste Minimization. prePrints, Vol. I:157-163.

FOSTER, S\& GOMES D.C. - 1989 - Groundwater Quality Monitoring: An Appraisal of Practices and costs. WHO-PAHO-CEPIS, 104 pp, Lima, Peru. 
FREEZE, R.A. \& CHERRY, J.A.- 2979 - Groundwater. Prentice Hall, 1: ed, 604 pp., New Jersey, EUA.

GEOKLOCK - 1990 - Serv. Proj. Geol. Min. Ltda - Mapeamento dos Residuos solidos da Fazenda TIBRÁs. Relatório não publicado, 15 pp. Săo Paulo.

HASSUDA, S. - 1989 - Impactos da Infiltração da Vinhança de Cana no Aquifero Baurú. Dissertação de Mestrado - Instituto de Geociências - USP, 92 pp., São Paulo.

HELZ, G.R., DAI J.H., KIJAK, P.J. e FENDINGER, N.J. - 1987 Processes Controlling the Composition of Acid Sulfate Solutions Evolved from Coal. Applied Geochemisty, Vol . 2: 427-436.

HERLIHY, A.T.; MILLS, A.L. e HERMAN, J.S. - 1988 Distribuition of Reduced Inorganic sulfur Compounds in Lake Sediments Recieving Acid Mine Drainage. Apllied Geochemistry, Vol. $3: 333-344$.

HOLTING, B. - 1984 - Hydrogeologie. ENKE, 2 a ed. 330 pp. Alemanha.

HORN, A. - 1992 - Untergrund, Basis-und oberflächen-dichtung von Abfalldeponien. Beitrag zur derzeitigen gesetzlichen regelung und zum stand der Technik. Bautechnik, 69 (9): 462473. Alemanha.

JACKS, G. - 1986 - Acidification of Water and Soil-A Short Summ ary of Principles and Processes. Water Quality Bulletin, Vol. 11 (4): 216-218.

JACKS, G. e NOORSTRÖM, A.C. - 1986 - SOil liming as an Amendment for Acid Groundwater. Water Quality Bulletin, Vol. 11 (4): $212-213$. 
KONSTEN, C.J.M.; MEULEN-SMIDT, G.R.B.; STIGLIANI, W.M., SALOMONS, W; e EIJSACKERS, H.- 1993 - Summary of the Workshop on Delayed Effects of Chemicals in Soil and Sediments (Chemical Time Bombs), with Emphasis on the Scandinavian Region. Applied Geochmistry, Suppl. Issue n. 2: 295-299.

KRAUSKOPF, K.B. - 1972 - Introdução à Geoquímica. Tradução de M. LANDO \& P.S.C. BOGUS. EDUSP - POLIGONO, 2 VOI., São Paulo. MANDEL, S. \& SHIFTAN, S.L. - 1981 - Groundwater Resoures Investigation and Development. Cap. 6 - Pumping Tests: 140165. Academic Press. EUA.

MARSILY, G. de - 1986 - Quantitative Hydrogeology - Groundwater for Engineers. Academic Press, $400 \mathrm{pp.} \mathrm{EUA.}$

MONIZ, A.C. (Coord.) - 1975 - Elementos de Pedologia. EDUSP / LIVROS TECNICOS E CIENTIFICOS ED., 460 pp, Rio de Janeiro.

MOTOR COLUMBUS - 1987- Essais de pompage et Leur Interpretation. Technische Unterlagen Nr. 15, Relatório Não Publicado, $60 \mathrm{pp}$. Baden, Suíça.

NORTON, P.J. - 1993 - Engineered Wetlands and AMD. Mining Environmental Manegement. p. 12-13, setembro.

NYER, E.K. - 1993 - Practical Techniques for Groundwater and Soil Remediation. Geraghty \& Miller Environmental Science \& Engeneering Series, 214 pp. Lewis Publ., EUA.

ORGANIZAÇÃO INTERNACIONAL DO TRABALHO (OIT) - 1975 Enciclopedia de Medicina, Hygiene y Seguridad del Trabajo. Publicado pelo Min. de Trabajo da Espanha. 2 Vol, 1670 pp. Madrid, Espanha. 
PORTO, R.L. (OIg.); BRANCO, S.M.; CLEARY, R.W.; COIMBRA, R.M.; EIGER, S.; LUCA, S.J.; NOGUEIRA, V.P.Q.; e PORTO, M.F.A. - 1991 - Hidrologia ambiental. Vol 3. Coleção ABRH de Recursos Hidricos. ABRH/EDUSP, 440 pp. São Paulo.

REBOUÇAS, A.C. - 1990 - Groundwater Use and Protection in Petrochemical Complex Region, Camaçari, Bahia, Brazil. IAWPRC International Seminar on Industrial Residuals Manegement: 147156. - Salvador, BA (ed. by Fontes Lima, F.J. e Almeida, A.S.).

SHREVE, R.N. \& BRINK Jr., J.A. - 1977 - Indústrias de Processos Químicos. Tradução de Horácio Macedo. Editora Guanabara, 4 a ed., 717 pp., Rio de Janeiro.

STANDARD METHODS FOR THE EXAMINATION OF WATER AND WASTEWATER - $1985-16^{\text {th }}$ ed. APHA. EUA.

TARUTIS Jr., W.J.; UNS, R.F. e BROOKS, R.F. - 1992 - Behaviour of Sedimentary $\mathrm{Fe}$ and $\mathrm{Mn}$ in a Natural Wetland Recieving Acid Mine Drainage, Pennsylvania, U.S.A. Apllied Geochemistry, Vol. $7: 77-85$.

TODD, D.K.; e MCNULTY, D.E.O. - 1976 - Polluted Groundwater: Review of the significant Literature. Water Inf. Center. Inc. $179 \mathrm{pp} ., \mathrm{EUA}$.

WICKS, C.M.; HERMAN, J.S. e MILLS, A.L. - 1991 - EarIY Diagenesis of Sulfur in the sediments of Lakes that Recieve Acid Mine Drainage. Apllied Geochemistry, Vol. 6: 213 - 224 . 